\title{
Influence of the TGF- $\beta$ Superfamily on Osteoclasts/Osteoblasts Balance in Physiological and Pathological Bone Conditions
}

\author{
Jessica Jann ${ }^{1}$, Suzanne Gascon ${ }^{1}$, Sophie Roux ${ }^{2}$ and athalie Faucheux ${ }^{1,3, *(1)}$ \\ 1 Laboratory of Cell-Biomaterial Biohybrid Systems, Department of Chemical and Biotechnological Engineering, \\ 2500 Boulevard Université, Université de Sherbrooke, Sherbrooke, QC J1K 2R1, Canada; \\ Jessica.Jann@usherbrooke.ca (J.J.); Suzanne.Gascon@USherbrooke.ca (S.G.) \\ 2 Department of Rhumatology, CHUS, 3001 12th Avenue N, Sherbrooke, QC J1H 5N4, Canada; \\ Sophie.Roux@USherbrooke.ca \\ 3 Centre de Recherche du CHUS, 3001 12th Avenue N, Sherbrooke, QC J1H 5N4, Canada \\ * Correspondence: Nathalie.Faucheux@USherbrooke.ca; Tel.: +1-819-821-8000 (ext. 61343)
}

Received: 22 September 2020; Accepted: 10 October 2020; Published: 14 October 2020

check for updates

\begin{abstract}
The balance between bone forming cells (osteoblasts/osteocytes) and bone resorbing cells (osteoclasts) plays a crucial role in tissue homeostasis and bone repair. Several hormones, cytokines, and growth factors-in particular the members of the TGF- $\beta$ superfamily such as the bone morphogenetic proteins-not only regulate the proliferation, differentiation, and functioning of these cells, but also coordinate the communication between them to ensure an appropriate response. Therefore, this review focuses on TGF- $\beta$ superfamily and its influence on bone formation and repair, through the regulation of osteoclastogenesis, osteogenic differentiation of stem cells, and osteoblasts/osteoclasts balance. After introducing the main types of bone cells, their differentiation and cooperation during bone remodeling and fracture healing processes are discussed. Then, the TGF- $\beta$ superfamily, its signaling via canonical and non-canonical pathways, as well as its regulation by Wnt/Notch or microRNAs are described and discussed. Its important role in bone homeostasis, repair, or disease is also highlighted. Finally, the clinical therapeutic uses of members of the TGF- $\beta$ superfamily and their associated complications are debated.
\end{abstract}

Keywords: bone morphogenetic proteins; osteoclastogenesis; osteogenic differentiation; smad signaling pathway; RANKL

\section{Introduction}

Bone tissue plays several essential physiological roles within the human body, in particular mechanical functions such as protection, rigid support, and an anchoring site for soft organs (skeletal muscles) and metabolic functions [1,2]. Indeed, as the storage place of essential minerals (calcium and phosphorus), bone is a dynamic tissue in perpetual remodeling, alternating the phenomena of resorption and bone formation, which ensures the control of bone and phosphocalcic homeostasis of the human body [2,3]. There are two major families of bone cells with complementary activities-bone-forming cells (osteoblasts, osteocytes, and lining cells) and bone-resorbing cells (osteoclasts). The osteoblast/osteoclast balance is essential in bone homeostasis and its remodeling process, as well as in the repair of bone fractures. Any imbalance in their activity leads to diseases such as osteoporosis and Paget's disease, which have strong consequences on the patient's quality of life [4]. For example, osteoporosis not only increases the risk of bone fracture [5], but it also impairs bone's inherent ability to self-renew, leading to non-unions $[4,6,7]$. 
Many cytokines, growth factors, hormones (PTH), and vitamins are involved in the phases of bone repair and remodeling [8-11]. The growth factors belonging to the TGF- $\beta$ (transforming growth factor $\beta$ ) superfamily (particularly bone morphogenetic proteins (BMP) and TGF- $\beta 1$ ) are known to act locally on bone formation, by stimulating the proliferation and chondrogenic/osteogenic differentiation of mesenchymal stem cells (MSCs) [12]. Thus, they constitute promising local therapeutic agents to promote bone repair. However, their roles on osteoclasts are still not well understood $[13,14]$.

The TGF- $\beta$ superfamily is an evolutionary conserved family of structurally related dimeric factors. They are secreted growth factors, which act as multifunctional regulatory peptides involved in a wide range of processes, including cell development, proliferation, and differentiation; wound healing; and carcinogenesis $[15,16]$. The TGF- $\beta$ superfamily consists of several subfamilies, the TGF- $\beta$, Nodal, Activin subfamily and the BMP, growth and differentiation factor (GDF), anti-Müllerian hormone/Müllerian inhibiting substance (AMH/MIS) subfamilies.

In this review, the roles of bone-forming and bone-resorbing cells and their cooperation in healing and bone remodeling processes are presented. We will then introduce the role of the members of the TGF- $\beta$ superfamily, their canonical/non-canonical signaling pathways and their respective regulations (Wnt/Notch, antagonist proteins, microRNAs) and discuss the complexity of their mechanisms that influence homeostasis and bone disease. Finally, the controversial clinical uses of members of the TGF- $\beta$ superfamily in orthopedic surgery is debated.

\section{Osteoblast/Osteoclast Balance in Bone Remodeling and Repair}

\subsection{Bone Forming Cells}

\subsubsection{Osteogenic Differentiation}

Osteoblasts develop from MSCs or osteoprogenitor cells. MSCs/progenitors can differentiate into chondrocytes, osteoblasts, or adipocytes, in response to specific growth factors and cytokines, such as BMPs and Wnt [17-19]. The source of osteoblast progenitors in vivo is still under debate. They can be found in bone marrow (MSCs accounting for 0.001 to $0.01 \%$ nucleated cells) and periosteum [20,21]. Recently, new osteoprogenitors called transcortical perivascular cells $\left(2-3 \%\right.$ of Lin $^{-}$cells from the digested cortical bone fraction) were identified [22].

The commitment of MSCs/progenitors to the osteoblast lineage depends on the activation of several transcription factors, such as the runt-related transcription factor 2 (Runx2) that acts upstream from Osterix ( $S p 7$ encoding for Osterix (Osx)) [23-25]. Runx2 is also involved in the proliferation of osteoprogenitor cells, by inducing the expression of the genes encoding fibroblast growth factor (FGF), FGF-2, and FGF-3 [26]. Both Osterix and Runx2 are required to induce the expression of genes encoding osteogenic markers [27]. In addition, the transcriptional activity of Runx2 and Osterix depends on their phosphorylation state at specific Ser residues [28,29].

In contrast, PPAR $\gamma$ (peroxisome proliferation-activated receptor $\gamma$ ) and CEBP $\alpha$ (CCAAT-enhancer binding protein $\alpha$ ) are transcription factors that promote the adipogenic commitment of MSCs [30]. However, activation of Runx2 in MSCs appears to prevent their commitment into the adipocyte lineage [31]. The mechanisms based on Wnt and MAPK (Mitogen-activated protein kinase) pathways that control reciprocal expression of Runx 2 and PPAR $\gamma$ and their phosphorylation state are essential in MSCs fate determination [32].

\subsubsection{Osteoblast and Osteocyte Functions}

Osteoblasts that represent around 5\% of the bone resident cells are located at the bone surface [33]. They are responsible for the organic matrix synthesis called osteoid and its mineralization. These cells mainly synthesize type I collagen ( $90 \%$ of osteoid), adhesion proteins (e.g., fibronectin, thrombospondin (TSP)), members of small integrin-binding ligand N-linked glycoprotein (SIBLING) family-like bone sialoprotein (BSP), and osteopontin, as well as proteoglycans (e.g., decorin, biglycan) [34-36]. 
The mineralization process, which leads to the nucleation and growth of hydroxyapatite microcrystals $\left[\mathrm{Ca}_{10}\left(\mathrm{PO}_{4}\right)_{6}(\mathrm{OH})_{2}\right]$, is still under investigation (for review see [37]).

When mature osteoblasts are surrounded by secreted extracellular matrix, they undergo some morphologic changes characterized by a decreased volume, number of organelles, and star-shaped cell, to become osteocytes (for review on osteocytes see [38]). These cells, accounting for $90-95 \%$ of all resident bone cells, can survive several decades, depending on bone turnover rate, unlike osteoblasts (up to 5 months) and osteoclasts (few days) [39,40]. The osteocytes are now considered to be mechanosensory and endocrine cells that play a crucial role in bone homeostasis and remodeling, by regulating both osteoclast and osteoblast functions [38].

\subsection{Bone Resorbing Cells}

\subsubsection{Osteoclastogenesis}

The multinucleated giant mature osteoclasts, accounting for $1 \%$ of all resident bone cells, are derived from myeloid precursors through the macrophage/dendritic cell lineage, following a multistep process called osteoclastogenesis. This process takes place in the bone marrow, adjacent to bone surfaces [33,41]. First, monocyte/macrophage precursor cells are committed into the osteoclast lineage. After a first phase of proliferation that is essential for differentiation to occur, the mononuclear osteoclastic precursors merge together, and gradually acquire the characteristics of multinucleated osteoclasts. The osteoclastic markers appear (tartrate-resistant acid phosphatase (TRAP), calcitonin receptor (CTR), $\alpha_{\mathrm{v}} \beta_{3}$ integrin), while the macrophagic markers disappear (nonspecific esterase (NSE), Mac-1). Then, they finally undergo maturation after adhesion to bone, in order to become polarized active osteoclasts that can form resorption lacunae [42].

Osteoclastogenesis mainly depends on two cytokines, the macrophage-colony stimulating factor (M-CSF) and the receptor activator of nuclear factor kappa beta ligand (RANKL) [43] (for review see [44]; Figure 1). M-CSF, also called colony stimulating factor 1 (CSF-1), is expressed by various cells including adipogenic mesenchymal stromal cells (adipocytic-primed leptin receptor positive cells), bone lining cells, osteoblasts, as well as microvascular endothelial cells [45-47]. M-CSF is recognized by the CSF-1 receptor c-Fms. Upon binding to its receptor, M-CSF activates the phosphoinositide 3-kinase (PI3K)/Akt and growth factor receptor bound protein 2 (Grb2)/extracellular signal-regulated kinase (ERK) pathways, leading to osteoclast precursor proliferation and survival [48].

RANKL-also called ODF (osteoclast differentiation factor), OPGL (osteoprotegerin ligand), or TRANCE (tumor necrosis factor-related activation-induced cytokine)—is expressed by osteogenic stromal cells, osteoblasts, proliferative chondrocytes, and lining cells [49,50]. Osteocytes are a major source of RANKL [51,52], and osteocyte-derived RANKL is essential for osteoclast formation [53]. RANKL can exist as a transmembrane protein or soluble form, after its cleavage by proteases [54]. 


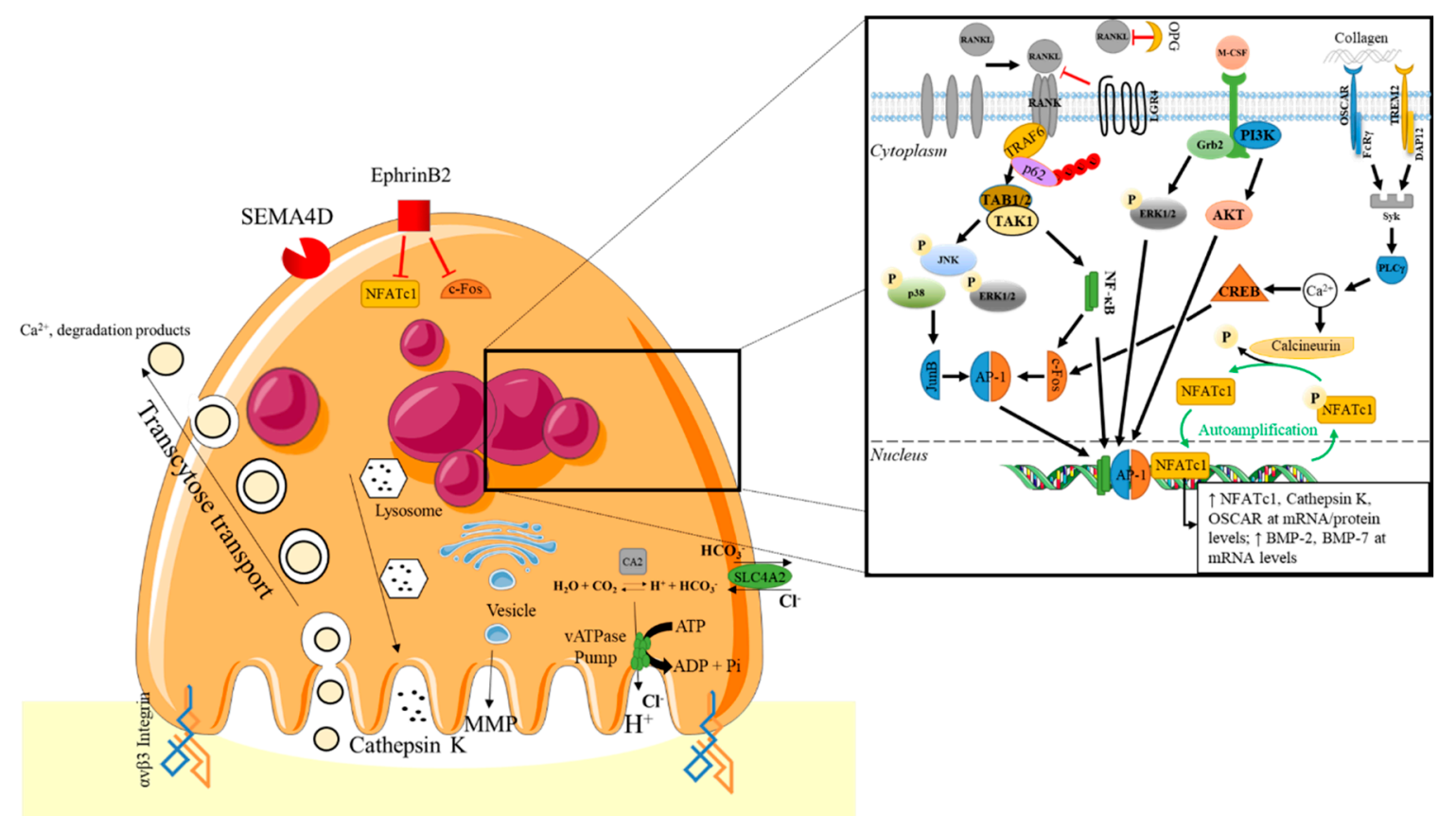

Figure 1. Osteoclast inducing bone resorption and its regulation by M-CSF, RANKL, and OSCAR/TREM2 signaling [55-59]. AP1: activator protein 1; CA2: carbonic anhydrase enzymes; CREB: cyclic AMP Response Element-binding protein; DAP12: DNAX associated protein 12kD size; ERK: extracellular signal-regulated kinase; Grb2: growth factor receptor bound protein 2; JNK: c-Jun amino (N)-terminal kinases; LGR4: Leucine rich repeat containing G-coupled receptor 4; M-CSF: macrophage- colony stimulating factor; NFATc1: nuclear factor of activated T cells; NF- $\mathrm{kB}$ : nuclear factor of $\kappa \mathrm{B}$; OPG: Osteoprotegerin; OSCAR: osteoclast-associated receptor; PI3K: Phosphoinositide 3-kinase; PLC $\gamma$ : phospholipase $C \gamma$; SLC4A2: Solute Carrier Family 4 Member 2; TAB1-2: TAK1-binding protein 1-2; TAK1: transforming growth factor $\beta$-activated kinase 1 ; TRAF: TNFR-associated factors; TREM2: Triggering receptor expressed on myeloid cells-2. The figure was created using Servier Medical Art. https://smart.servier.com.

RANKL binds to RANK a member of the tumor necrosis factor (TNF) receptor superfamily found on osteoclast precursors [60]. It was also recently found that the N-terminal extracellular domain of LGR4 (leucine rich repeat containing G-coupled receptor 4) compete with RANK to bind RANKL [61]. Upon RANKL binding to RANK, a homotrimeric transmembrane protein complex is formed, which induces the recruitment of the TNFR-associated factors (TRAFs), like TRAF6, leading to TAB1-2 ((TAK1-binding protein 1-2)/TAK1 (transforming growth factor $\beta$-activated kinase 1)) activation [60]. The p62 scaffolding protein, encoded by SQSTM1, is one of the functional links reported between RANKL and TRAF6-mediated signals [62]. Then, several intracellular pathways such as MAPK (p38, JNK, and ERK) or Akt are activated, leading to the stimulation of transcription factors, such as activator protein 1 (AP-1), nuclear factor of $\kappa B$ (NF- $k B$ ), Micropthalmia-associated transcription factor (MITF), c-Fos, or the master transcription regulator nuclear factor of activated $\mathrm{T}$ cells (NFATc1). These transcription factors are essential for the osteoclastogenesis and osteoclast maturation, by promoting the expression of genes encoding TRAP, v-ATPase subunit $\mathrm{d} 2$ (Atp6v0d2), osteoclast-associated receptor (OSCAR), 33 integrin subunits, and cathepsin K [63]. Indeed, specific receptors such as DAP12 (DNAX associated protein $12 \mathrm{kD}$ size) and FcR $\gamma$, as well as integrins $\left(\alpha_{\mathrm{V}} \beta_{3}\right.$ and $\left.\alpha_{\mathrm{V}} \beta_{5}\right)$, play a crucial role in the osteoclastogenesis and osteoclast function [64-66]. For example, FcR $\gamma$ and DAP12, with their respective associated receptors OSCAR and TREM2 (triggering receptor expressed on myeloid cells-2) are essential for NFATc1 activation via Syk/PLC/Ca ${ }^{2+}$ downstream signaling [64]. 
Several pro-inflammatory cytokines such as TNF- $\alpha$ and interleukins (IL) like IL-1, IL-7, IL-8, IL-11, and IL-15, can induce the osteoclastogenesis [67-69]. For example, TNF- $\alpha$ in vitro induced the formation of multinucleated cells' ability to resorb bone in the presence of M-CSF [68].

TNF- $\alpha$, IL-1 $\beta$, IL-6 IL-7, and IL-15 can also induce the expression of M-CSF or RANKL [70,71]. Nevertheless, there are some discrepancies in the literature regarding the role played by some ILs, such as IL-6, during osteoclastogenesis [72-74]. For example, IL-6 (100 ng/mL) appears to suppress the osteoclast progenitor differentiation induced by M-CSF plus soluble RANKL (100 ng/mL) in vitro [73]. In contrast, the inhibition of IL-6 receptor by antibodies decreased the osteoclast formation by both mouse spleen cells treated with M-CSF ( $30 \mathrm{ng} / \mathrm{mL}, 24 \mathrm{~h}$ alone before adding RANKL) and RANKL $(50 \mathrm{ng} / \mathrm{mL})$ in vitro and in TNF $\alpha$-transgenic mice in vivo [75].

\subsubsection{Mature Osteoclast Functions}

Osteoclasts are the only known cells that can resorb bone. This resorption depends on the ability of osteoclasts to interact with the bone matrix. At early stages of differentiation in vitro, osteoclasts form a primary specialized adhesion structure called podosome [76,77]. These podosomes are first organized into clusters associated with an actin cloud that evolve into a ring pattern [77]. At the periphery of mature osteoclasts, the podosome rings fuse together to finally form a structure called a belt or a sealing zone, when the cells adhere to the bone matrix [77,78]. Park et al. recently found that interaction between RACK1 and c-Src mediated by TRAF6 is required for osteoclast-mediated actin ring formation and cytoskeletal reorganization, during the process of bone resorption [79].

The sealing zone, characterized by the formation of the bone-apposed ruffled border membrane and the isolated resorption lacuna, segregates the resorptive microenvironment from the general extracellular space (Figure 1) $[80,81]$. The ruffled border membrane is involved in the transport into the resorption lacuna of proteolytic enzymes, as well as protons, via the vacuolar protons-transporting adenosine triphosphatase (v-ATPase) pump. The protons $\mathrm{H}^{+}$are obtained by the activity of carbonic anhydrase enzymes (CA2) that catalyze the production of carbonic acid $\left(\mathrm{H}_{2} \mathrm{CO}_{3}\right)$ from carbon dioxide and water [82]. The released protons allow the dissolution of the mineralized components of the bone matrix. The organic matrix made of type I collagen is then broken down by proteases such as Cathepsin K, which can also activate the matrix metalloproteases MMP-9, through cleavage [83,84]. Furthermore, it was recently shown that the deletion of both Mmp9 and Mmp14 genes in bone-marrow-derived myeloid cells altered the bone resorption activity of osteoclasts [85].

\subsection{Osteoblasts/Osteoclasts Balance}

\subsubsection{Bone Remodeling}

Bone remodeling is a physiological dynamic and continuous process in which old bone is degraded and replaced to maintain its strength and mineral homeostasis. Osteoclasts and osteoblasts orchestrate the bone remodeling process via the formation of 'basic multicellular unit' (BMU) [81]. For example, the human adult skeleton has about 1-2 million active BMUs that function in an asynchronous manner to renew $3-10 \%$ of the bone tissue per year [38]. The bone remodeling process can be divided into six major phases [86]. The first one is the quiescence phase, followed by the second phase, called activation. The second phase is initiated by the activation of osteocytes induced by mechanotransduction or apoptosis of neighboring osteocytes, placed in a hypoxic environment, due to bone microcracks formation. The activated osteocytes in turn release several pro-inflammatory cytokines, such as TNF- $\alpha$, which are known to attract osteoclast progenitors and promote their differentiation [68]. It was also proposed that osteocyte apoptosis directly promotes the osteoclastic bone resorption activity, but the soluble factors involved in this phenomenon were not identified. Indeed, osteoprotegerin (OPG), soluble decoy receptor that sequesters RANKL, was undetected [87]. However, another study found that there is a constant baseline bone remodeling, which is independent 
of the osteocyte apoptosis, when there are fewer than 45 apoptotic osteocytes $/ \mathrm{mm}^{2}$ [88]. The third phase is the resorption, which implies that recruited osteoclast progenitors must undergo complete osteoclastogenesis, to become mature osteoclasts. The release of RANKL by osteocytes and osteoblasts is strongly involved in this phase. Mature osteoclasts degrade bone matrix to generate Howship's resorption lacunae, by dissolving the mineral phase and degrading the organic matrix through specific collagenases (MMP) and proteases (as described in Section 2.2.2). The fourth phase is the reversal that is characterized by the removal of collagen fragments and debris by "osteomacs", and the death of almost all osteoclasts through apoptosis [89]. During this phase, the recruitment of the osteoprogenitors begins, such as that of the bone lining cells, which are also major contributors of preosteoblasts in bone remodeling [49]. The fifth phase, the bone formation, is induced by the differentiation of recruited osteoprogenitors and the formation of mineralized bone matrix, by mature osteoblasts. The sixth phase, the terminal phase, includes the arrest of bone matrix synthesis through terminal differentiation of the embedded osteoblasts into osteocytes. The osteoblasts can also die by apoptosis (around 50-70\%) or become bone lining cells. The osteocytes are involved in this arrest through the local release of sclerostin $[90,91]$. Indeed, the overexpression of SOST (gene encoding sclerostin) in transgenic mice reduces the bone mass [92]. Furthermore, the patients suffering from sclerosteosis and van Buchem disease (also known as hyperostosis corticalis generalisata), characterized by high bone mass, present a loss of the SOST gene function and SOST deletion on chromosome 17q (17q12-21 deletion), respectively $[93,94]$.

Thus, the communication between osteoblasts/osteocytes and osteoclasts, play a crucial role during the bone remodeling process [95]. The osteoblasts/osteocytes can regulate the osteoclastogenesis by synthetizing RANKL or OPG (decoy receptor sequestering RANKL), which can promote or suppress osteoclastogenesis, respectively [96]. For example, under mechanical loading, the osteoblasts synthesize OPG via IL-6 stimulation, decreasing osteoclast formation [97]. In addition, the synthesis of sclerostin by osteocytes is decreased under mechanical stimulation, enabling bone formation [98]. Osteoblasts can produce semaphorins such as Sema3A, which interacts with neuropilin-1 present in the membrane of bone marrow-derived monocyte/macrophage precursors, to inhibit osteoclastogenesis. In contrast, osteoclasts, by expressing Sema4D through its binding to plexin-B1 receptors on osteoblast, inhibits bone formation $[99,100]$. Osteoclasts and osteoblasts can also interact together through their respective protein, ephrinB2 and EphB4. EphrinB2 favor osteogenic differentiation and osteoblast survival by limiting apoptosis, while it inhibits bone resorption by preventing c-Fos-NFATc1 signaling [101,102].

\subsubsection{Bone Fracture Healing}

Bone healing involved intramembranous and endochondral processes. Intramembranous process occurs in fractures without any bone fragment displacement, which are also mechanically stable. The healing of larger bone fractures involves both endochondral bone formation and intramembranous healing [103].

Endochondral process occurs in three major phases-inflammation and hematoma formation, then bone repair (fibrocartilaginous and bony callus formation), and finally bone remodeling [104]. During the phase of inflammation and hematoma formation, the platelet-fibrin clot acts as a transitory scaffold that is able to recruit cells involved in the acute inflammation, via the presence of cytokines, such as IL-1 and IL-6, as well as chemoattractants like CXCL12 [105-107]. Interestingly, Burska et al. recently found an increase in IL- $1 \beta$ and IL-6, but not in TNF- $\alpha$, during the early hematoma and inflammation phase in humans. Then, the levels of both IL-1 and IL-6 decrease while that of TNF- $\alpha$ increases [105]. The recruited neutrophils and M1 macrophages (until day 3) remove the damaged cells and tissue [108]. During the resolution of acute inflammation, macrophages evolve to M2 phenotype, and the MSCs are recruited by a gradient of cytokines and chemoattractants, such as CXCL12 and MCP-1 (also called CCL2) $[8,105,108]$. The bone repair phase is initiated by the formation of the fibrocartilaginous callus. The recruited MSCs differentiate into chondrocytes, which synthesize and secrete a cartilage matrix made of type II collagen and glycosaminoglycans [109]. 
Then, chondrocytes become hypertrophic and mineralize the cartilaginous matrix. After the death of hypertrophic chondrocytes through a process that might be independent of apoptosis, a transition from fibrocartilagenous callus to bony callus occurs [110]. It is promoted by angiogenesis (vascular endothelial growth factor, VEGF) and the differentiation of precursor cells into mature osteoblasts leading to bone formation and mineralization [9]. Finally, the last stage of bone healing is the bone remodeling, which involves both osteoclasts and osteoblasts, as described in Section 2.3.1.

Each phase of bone fracture repair and remodeling requires different hormones (PTH, 1,25-(OH)2D3), cytokines, growth factors, such as insulin like growth factor (IGF), FGF, and members of the TGF- $\beta$ superfamily synthesized by bone cells [8-11]. Before describing the regulation of bone fracture healing phases by the TGF- $\beta$ superfamily, this review first introduces the members of this superfamily, their signaling pathways, as well as crosstalk with Wnt and Notch signaling.

\section{The TGF- $\beta$ Superfamily}

\subsection{Members of the TGF- $\beta$ Superfamily}

To date, the TGF- $\beta$ superfamily contains more than 30 members, including the TGF- $\beta$ /Nodal/Activin (Inhibin) family, the BMP/growth differentiation factors (GDF) family, and the group of anti-Müllerian hormone/Müllerian inhibiting substance (AMH/MIS).

Members of the TGF- $\beta$ superfamily are secreted growth factors, which act as multifunctional regulatory proteins in bone, being involved in a wide range of processes, including the proliferation, differentiation, and function of bone cells. They also coordinate the communication between osteoblasts and osteoclasts to ensure an appropriate response.

\subsubsection{TGF- $\beta$ /Nodal/Activin Family}

- $\quad$ TGF- $\beta$

TGF- $\beta$ s were discovered by De Larco and Todaro [111]. Using the cell culture supernatant of mouse 3T3 fibroblasts transformed by a Moloney murine sarcoma virus, a family of growth-stimulating polypeptides called sarcoma growth factors (SGFs) was first identified and purified [111]. These SGFs not only stimulated the proliferation of the fibroblasts in a monolayer culture, but also acted as "effectors of fibroblastic cell transformation", allowing them to grow in an anchorage-independent manner, in soft agar [111]. Further studies were then carried out to identify and purify TGF- $\beta$ s from SGFs and other tissues [112-114].

There are three TGF- $\beta$ isoforms in mammals, TGF- $\beta 1$, TGF- $\beta 2$, and TGF- $\beta 3$, each encoded by genes located at different chromosomes (in human chromosome 19, 1, and 14, respectively) [115-117]. The TGF- $\beta$ isoforms are synthesized as pre-pro-TGF- $\beta$ monomers [118]. Each monomer contains an N-terminal signal peptide (SP, 29 amino acid residues), a pro-region called latency associated peptide (LAP, 249 amino acid residues) for proper folding of the growth factor, and a C-terminal mature growth factor domain (112 amino acid residues) [119]. After SP removal by cleavage, pro-TGF- $\beta$ are dimerized via the formation of disulfide bonds. In the trans Golgi, the LAP dimers are then cleaved from the dimeric growth factor domains, by the endopeptidase furin, but remain non-covalently bonded to them. Thus, TGF- $\beta$ s are usually secreted as latent complexes containing the dimeric growth-factor domains noncovalently bond with LAP dimers [118]. These complexes can also interact via the LAP dimers with other extracellular matrix components such as fibrillin, and latent TGF- $\beta$ binding protein (LTBP), favoring the sequestration of the growth factor into the matrix for later activation [120]. In fact, these interactions might stabilize the latent TGF- $\beta$ state due to the cross-armed conformation of the pro-TGF- $\beta$ complexes, the growth factor remaining unable to interact with its Thr/Ser kinase receptors [121]. Indeed, $\mathrm{Mi}$ et al. hypothesized that cross-armed conformation of TGF- $\beta$ family members corresponds to a latent state of the growth factor, while the open-armed conformation characterizes its mature active form [121]. Mature active TGF- $\beta$ can be released from LAP and LTBP, through different latent TGF- $\beta$ activators like proteases or membrane receptors. For example, $\alpha_{v} \beta_{6}$ or 
$\alpha_{\mathrm{v}} \beta_{8}$ integrins that recognize the Arg-Gly-Asp motif in the pro-domains of TGF- $\beta 1$ and TGF- $\beta 3$, can exert a tensile force across the LTBP-LAP-TGF- $\beta$ complexes, to release the mature form of the growth factor $[120,122]$.

The sequence homology analyses revealed a high percentage of amino acid identity between the mature forms of the TGF- $\beta$ s, which varied from around $71 \%$ (TGF- $\beta 1$ and TGF- $\beta 2$ ) to $80 \%$ (TGF- $\beta 3$ and TGF- $\beta 2)[123,124]$. However, several studies showed non-overlapping phenotypes of TGF- $\beta 1$, TGF- $\beta 2$, and TGF- $\beta 3$ in knockout mice, suggesting that various functions are not compensated by other TGF- $\beta$ isoform [125-127]. For example, using TGF- $\beta 1$ null mutation in the homozygous state, Kulkarni et al. observed intrauterine death for around $65 \%$ of the embryos. The surviving mice that appear clinically normal at birth, develop uncontrolled inflammatory response in the heart and lungs, after 14 days, leading to their death within 2 weeks [125]. In contrast, TGF- $\beta 3$-null embryos show a different phenotype from these TGF- $\beta 1$ knockout mice with major deficiency in the palatal shelf fusion process [126]. Finally, TGF- $\beta 2$ knockout mice possess aberrant skeletogenesis (skeletal induction and growth). In addition, while $66 \%$ of TGF- 32 -deficient mice die shortly before or during birth because of multiple developmental defects, especially those affecting the heart, the surviving mice are cyanotic [127].

\section{- $\quad$ Activin/Nodal}

This review does not describe Nodal, despite its role in embryonic development and maintenance of stem cell pluripotency, because it is not expressed in adult non-neoplastic tissues [128] (for review see [129]). Activin was first discovered in the 1980s by Vale et al. as a dimeric polypeptide consisting of two inhibin $\beta \mathrm{A}$-chains linked by disulfide bonds, which are able to induce the synthesis and release of the follicle-stimulating hormone FSH $[130,131]$. In mammals, 5 activins (activin A, B, AB, C, and E) were identified. These were characterized by the combination of inhibin subunits $(\beta a, \beta b, \beta c, \beta e)$ that formed homodimers or heterodimers. For example, the activin $\mathrm{A}$ is composed of inhibin $\beta$ a dimer, while the activin $A B$ is made of inhibin $\beta a$ and inhibin $\beta b$. The active mature form of activin is obtained after the cleavage of the secreted pro-activin through proteases like furin releasing the $\mathrm{N}$-terminal prodomain $[132,133]$. Knockout mice for activin A appear healthy at birth, despite the lack of whiskers, but die within 1 day due to abnormal craniofacial development (defective palate) [134,135].

\subsubsection{BMP/GDF Family}

Urist discovered the biomolecules responsible for the new bone formation in 1965, called BMP, after implantation of $\mathrm{HCl}(0,6 \mathrm{~N})$-decalcified bone matrix in the rectus abnominus of several animal models (mouse, rat, guinea pig, rabbit) and rabbit quadriceps [136]. Currently $20 \mathrm{BMPs} / \mathrm{GDFs}$ are identified. Several classifications were proposed to regroup the members of the BMP/GDF family. For example, these were classified into seven subgroups based on the sequence residue homologies in their carboxy-terminal mature growth factor domain [137-140]. BMP-2 and BMP-4 with around $92 \%$ amino acid identities are members of the Drosophila decapentaplegic (dpp) subgroup (subgroup I). BMP-5, BMP-6, -BMP-7, and BMP-8 are members of the Drosophila 60A subgroup (subgroup II). These BMPs share less than 65\% residues identities with BMP-2 [139]. BMP-9 (GDF 2) and BMP-10 with around $65 \%$ amino acid identities are members of the subgroup III. The other subgroups are: (IV) GDF5 (BMP-14), GDF 6 (BMP-13), and GDF 7 (BMP-12); (V) Myostatin (GDF8) and GDF 11; (VI) GDF 1 and GDF3; and (VII) GDF 10 and BMP-3 [137-140]. A classification of 14 BMPs into three subgroups was recently proposed [141]. This new classification was established based on the clustering analyses of 519 genes transcriptomic profiles (e.g., genes encoding Ser/Thr kinases, Noggin, Smad6, Smad7, Id, parathyroid hormone receptor $1, \mathrm{Wnt}$ ) in multipotent murine $\mathrm{C} 3 \mathrm{H} 10 \mathrm{~T} 1 / 2$ stem cells transduced by adenovirus expressing BMPs. BMP-2, BMP-4, BMP-6, BMP-7, and BMP-9, which are well-known to induce multilineage differentiation of mesenchymal stromal cells, are members of the first subgroup. BMP-5, BMP-11, BMP-12, BMP-13, BMP-14, and BMP-15, which are involved in the repair of tendon and ligament injuries, are members of the second subgroup [141]. Interestingly, the third subgroup 
contains BMPs with various functions, such as BMP-3, BMP-8, and BMP-10. Indeed, BMP-3 is known as a negative regulator of bone density and bone formation [142], while BMP-8 and BMP-10 are involved in postnatal spermatogenesis and cardiac development, respectively [143,144].

As for TGF- $\beta s$, BMPs are synthesized as pre-pro-BMPs. For example, the pre-pro-BMP-9 contains a SP of 22 residues, a pro-domain of 297 residues and a 110 residues mature growth factor domain [145]. After SP removal, the pro-BMPs form dimers that are then cleaved by subtilisin-related pro-protein convertases (furin), favoring the formation of complexes through noncovalent association between the pro-domain fragments and the growth factor domain $[145,146]$. After secretion, the pro-BMP complexes can interact with the extracellular matrix to get a cross-armed conformation that induces the latency of the growth factor [147]. However, unlike pro-TGF- $\beta 1$, some pro-BMP complexes such as pro-BMP-7 and pro-BMP-9 can also adopt an open-armed conformation after secretion. This conformation allows their binding to Ser/Thr kinase receptors and signal transduction, despite the presence of non-covalent interactions with the pro-domain fragments $[121,148]$. For example, using human pulmonary artery endothelial cells, Salmon et al. recently showed that pro-BMP-9 complexes and BMP-9 induce the same expression of the gene encoding the inhibitor of DNA binding protein 1 (ID1), suggesting a similar signal transduction efficiency [149].

Among the members of the BMPs/GDFs family, BMP-2, BMP-4, BMP-5, BMP-6, BMP-7, and BMP-9 are well-known to induce the differentiation of osteoprogenitor cells into osteoblasts [150-154]. However, the use of knockout mice revealed that some BMPs are not only involved in skeletogenesis, but also induce defects in several organs, such as heart, kidney, and lungs [155]. For example, most of the homozygous null Bmp4 mutants die in early gastrulation, but the surviving embryos display a lack of allantois as well as primordial germ cells, both derived from precursors in the proximal epiblast $[156,157]$. In the same way, BMP-7-deficient mice die shortly after birth and not only have skeletal abnormalities in discrete areas such as rib cage, skull, and the hind limbs, but also eye and kidney defects [158].

\subsection{TGF- $\beta$ Superfamily Signaling Pathways and Their Regulation}

\subsubsection{The Canonical Pathways Used by Members of TGF- $\beta$ Superfamily}

Members of the TGF- $\beta$ superfamily act on cells by binding with different affinity to Type I and Type II Ser/Thr kinase receptors, leading to the activation of the canonical small mothers against decapentaplegic (Smad) or mitogen-activated protein kinase (MAPK) signaling pathways [159]. The Smad2/3 is activated by TGF- $\beta /$ Nodal/Activin family and members of the BMP/GDF subgroups V, VI, and VII (GDF8/GDF11; GDF1/GDF-3; and BMP-3/GDF-10), while Smad1/5/8 (also recently called Smad1/5/9) is initiated by BMPs of subgroups I to IV (Figure 2) [160-163]. However, in rare situations, activin and TGF- $\beta$ can also activate the Smad1/5/8 signaling $[164,165]$. Only a limited number of Type I and Type II Ser/Thr kinase receptors were identified in humans-seven type I (activin receptor-like kinases 1 to 7, ALK1-7) and five type II receptors (type II BMP receptor (BMPRII), type II activin receptor (ActRIIA), type IIB activin receptor (ActRIIB), TGF- $\beta$ RII (T $\beta$ RII), and anti-Mullerian hormone receptor type II (AMHRII)) [166-168]. These type I or type II receptors are characterized by a ligand-binding extracellular domain at their $\mathrm{N}$ terminal extremity, a single pass transmembrane part, and an intracellular domain at their C-terminal extremity, containing the Ser/Thr kinase activity $[169,170]$.

Our research team detected ALK1, ALK3, ALK6, and BMPRII receptors at both mRNA and protein levels in multinucleated cells (Table 1). Using double-immunofluorescence staining, we confirmed that CTR and RANK positive cells (osteoclasts) express ALK1 and BMPRII [171]. However, Kaneko et al. found that unlike BMPRIB (ALK6), both BMPRIA (ALK3) and BMPRII were expressed in isolated rabbit mature osteoclasts [172]. 
Table 1. Type I and type II receptors, TGF- $\beta$, and signaling in multipotent stem cells, osteoblasts, and osteoclasts [162,163,173-175].

\begin{tabular}{|c|c|c|c|c|}
\hline Type I Receptor & Type II Receptor & TGF- $\beta$ Ligands & $\begin{array}{l}\text { Signaling Pathway Activation in Osteoclast } \\
\text { Precursors and Mature Osteoclasts }\end{array}$ & $\begin{array}{c}\text { Signaling Pathway Activation in Stem Cells } \\
\text { and Osteoblast }\end{array}$ \\
\hline \multicolumn{5}{|c|}{ TGF- $\beta /$ Nodal/Activin family } \\
\hline \multirow[t]{2}{*}{ T $\beta$ RI (ALK5); ALK1 } & \multirow[t]{2}{*}{$\mathrm{T} \beta \mathrm{RII}$} & TGF- $\beta 1$ & $\begin{array}{c}\uparrow \mathrm{pSmad} 2 / 3 \text { (human M2 monocyte-derived } \\
\text { macrophages; } 10 \mathrm{ng} / \mathrm{mL} \text { ) [176]; } \\
\uparrow \text { Smad1/5 (human M2 monocyte-derived } \\
\text { macrophages; concentration is not } \\
\text { specified) [174]; } \\
\uparrow \text { Wnt10b and crosstalk between Smad2/3 and } \\
\text { canonical Wnt signaling (murine osteoclasts; } \\
2 \mathrm{ng} / \mathrm{mL} \text { ) [177] }\end{array}$ & $\begin{array}{c}\uparrow \text { pSmad2/3 (L6E9 myoblasts; }<0.01 \mathrm{ng} / \mathrm{mL} \text { ) [178]; } \\
\uparrow \text { pSmad1/5 (L6E9 myoblasts; }<1 \mathrm{ng} / \mathrm{mL} \text { ) [178]; } \\
\text { Crosstalk with Akt (early phase of osteoblast } \\
\text { differentiation MC3T3-E1; 0.1 ng/mL) [179]; } \\
\text { MAPK: } \uparrow \text { pERK1/2, } \text { pp38, } \text { pJNK (MC3T3-E1; } \\
\text { 2.5 ng/mL) [180]; } \\
\text { Canonical Wnt: } \uparrow \beta \text {-catenin via ALK5, Smad3 receptor } \\
\text { and PI3K (hMSC; } 1 \mathrm{ng} / \mathrm{mL})[181]\end{array}$ \\
\hline & & TGF- $\beta 3$ & N.A. & $\begin{array}{c}\text { 个 pSmad2/3 (mouse embryonic palatal mesenchymal } \\
\text { cells; } 10 \mathrm{ng} / \mathrm{mL} \text { ) [182]; } \\
\text { MAPK: } \uparrow \text { pERK1/2 (human mesenchymal stem cells; } \\
10 \mathrm{ng} / \mathrm{mL} \text { ) [183] }\end{array}$ \\
\hline $\begin{array}{l}\text { ActRIb } \\
\text { (ALK4) }\end{array}$ & ActRIIA; ActRIIB & Activin A & $\begin{array}{c}\uparrow \text { c-fos (murine macrophages RAW264.7; } 50 \\
\text { ng/mL of activin A with } 40 \mathrm{ng} / \mathrm{mL} \text { of } \\
\text { RANKL) [184]; } \\
\uparrow \mathrm{pS} \text { mad2/3 (RAW264.7; } 50 \mathrm{ng} / \mathrm{mL} \text { ) [184]; } \\
\uparrow \mathrm{pSmad} 2 / 3 \text { (murine bone marrow } \\
\text { macrophages; } 100 \mathrm{ng} / \mathrm{mL} \text { ) [185]; } \\
\text { MAPK: } \uparrow \text { pp38 and } \uparrow \mathrm{pERK} 1 / 2 \text { (murine bone } \\
\text { marrow macrophages; } 100 \mathrm{ng} / \mathrm{mL} \text { of activin A } \\
\text { with } 50 \mathrm{ng} / \mathrm{mL} \text { of } \mathrm{M}-\mathrm{CSF} \text { ) [185]. }\end{array}$ & $\begin{array}{l}\uparrow \mathrm{pSmad} 2 / 3 \text { (human endometrial stromal cells; } \\
\qquad<20 \mathrm{ng} / \mathrm{mL} \text { ) [186] }\end{array}$ \\
\hline \multicolumn{5}{|c|}{ BMP/GDF family } \\
\hline $\begin{array}{c}\text { BMPRIA (ALK3); BMPRIB } \\
\text { (ALK6); } \\
\text { ActRI }\end{array}$ & $\begin{array}{l}\text { BMPRII; ActRIIA; } \\
\text { ActRIIB }\end{array}$ & BMP-2 & $\begin{array}{c}\uparrow \text { Smad1/5/9 (murine bone marrow } \\
\text { mononuclear cells; } 100 \mathrm{ng} / \mathrm{mL} \text { ) [59]; } \\
\text { MAPK: } \uparrow \text { pERK and } \uparrow \text { pp38 (minimal) (murine } \\
\text { bone marrow mononuclear cells; } \\
100 \mathrm{ng} / \mathrm{mL} \text { ) [59]; } \\
\uparrow \text { pAkt (murine bone marrow mononuclear } \\
\text { cells; } 100 \mathrm{ng} / \mathrm{mL} \text { ) [59]; } \\
\uparrow \text { pSmad1/5 (osteoclasts precursor fusion; } \\
30 \mathrm{ng} / \mathrm{mL} \text { ) [187]; } \\
\text { MAPK: } \uparrow \text { pp38 (osteoclasts precursor fusion; } \\
30 \mathrm{ng} / \mathrm{mL} \text { ) [187] }\end{array}$ & 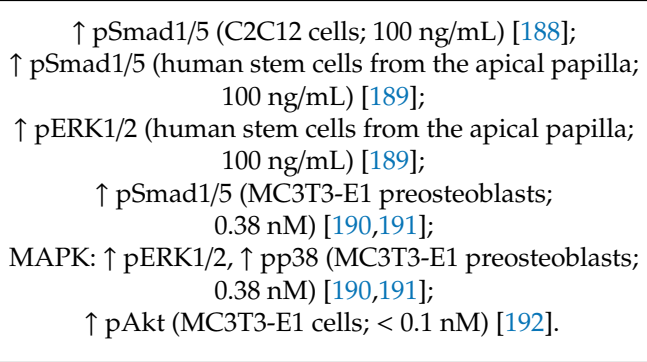 \\
\hline & & BMP-4 & N.A. & $\uparrow$ pSmad1/5 (C2C12 cells; 200 ng/mL) [193] \\
\hline
\end{tabular}


Table 1. Cont.

\begin{tabular}{|c|c|c|c|c|}
\hline Type I Receptor & Type II Receptor & TGF- $\beta$ Ligands & $\begin{array}{l}\text { Signaling Pathway Activation in Osteoclast } \\
\text { Precursors and Mature Osteoclasts }\end{array}$ & $\begin{array}{c}\text { Signaling Pathway Activation in Stem Cells } \\
\text { and Osteoblast }\end{array}$ \\
\hline \multirow{4}{*}{$\begin{array}{l}\text { BMPRIA (ALK3); BMPRIB } \\
\text { (ALK6); ALK2; } \\
\text { ALK1 }\end{array}$} & \multirow{4}{*}{ BMPRII; ActRIIA; ActRIIB } & BMP-5 & N.A. & $\begin{array}{c}\text { } \uparrow \text { pSmad1/5 (human embryonic stem cells; } \\
100 \mathrm{ng} / \mathrm{mL} \text { ) [194]; } \\
\text { MAPK: } \uparrow \text { pp38 (human embryonic stem cells; } \\
100 \mathrm{ng} / \mathrm{mL} \text { ) [194]; } \\
\text { MAPK: } \downarrow \text { pp38 (murine osteoblasts—differentiated } \\
\text { MC3T3-E1 cells; BMP-5 siRNA } 40 \text { nmol/mL) [195] }\end{array}$ \\
\hline & & BMP-6 & $\begin{array}{l}\uparrow \mathrm{pSmad} 1 / 5 \text { (rat and human granulosa cells; } \\
\qquad 100 \mathrm{ng} / \mathrm{mL} \text { ) [196]. }\end{array}$ & $\begin{array}{c}\uparrow \mathrm{pSmad} 1 / 5 \text { (C2C12 cells; } 200 \mathrm{ng} / \mathrm{mL} \text { ) [193]; } \\
\uparrow \mathrm{pSmad} 1 / 5 \text { (human embryonic stem cells; } \\
100 \mathrm{ng} / \mathrm{mL} \text { ) [194]; }\end{array}$ \\
\hline & & & & $\uparrow$ pSmad1/5 (MC3T3-E1 cells; 300 ng/mL) [175]. \\
\hline & & BMP-7 & 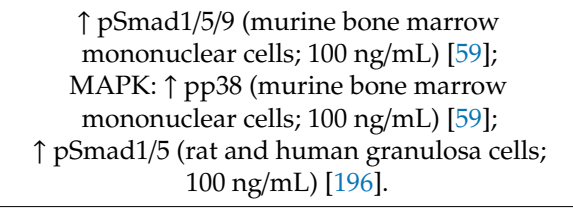 & $\begin{array}{c}\uparrow \text { pSmad1/5 (C2C12 cells; } 1000 \mathrm{ng} / \mathrm{mL} \text { ) [193]; } \\
\uparrow \text { pSmad1/5 (human embryonic stem cells; } \\
100 \mathrm{ng} / \mathrm{mL} \text { ) [194]; } \\
\text { MAPK: } \uparrow \text { pp38 (human embryonic stem cells; } \\
100 \mathrm{ng} / \mathrm{mL} \text { ) [194]. }\end{array}$ \\
\hline \multirow[t]{2}{*}{$\begin{array}{l}\text { ALK1 } \\
\text { ALK2 }\end{array}$} & \multirow[t]{2}{*}{ BMPRII; ActRIIA; ActRIIB } & $\begin{array}{l}\text { BMP-9 } \\
(\text { GDF-2) }\end{array}$ & $\begin{array}{l}\uparrow \mathrm{pSmad} 1 / 5 \text { (human cord blood monocyte as } \\
\text { osteoclast precursor; } 150 \mathrm{ng} / \mathrm{mL} \text { ) [171]; } \\
\text { MAPK: } \uparrow \mathrm{pERK} 1 / 2 \text { (human cord blood } \\
\text { monocyte as osteoclast precursor; } \\
150 \mathrm{ng} / \mathrm{mL} \text { ) [171] }\end{array}$ & $\begin{array}{c}\uparrow \text { pSmad1/5 (MC3T3-E1 cells; } 0.38 \mathrm{nM} \text { ) [190,191]; } \\
\text { MAPK: } \downarrow \text { pERK1/2, } \uparrow \text { pp38, } \uparrow \text { pJNK (MC3T3-E1 cells; } \\
\text { 0.38 nM) [190,191]; } \\
\uparrow \text { pAkt (MC3T3-E1 cells; }<0.1 \mathrm{nM} \text { ) [192]; } \\
\uparrow \text { pSmad1/5 (murine multipotent stem C3H10T1/2 } \\
\text { cells; } 10 \mathrm{ng} / \mathrm{mL} \text { ) [197]; } \\
\text { MAPK: } \uparrow \text { pp38 (C3H10T1/2 cells; } 10 \mathrm{ng} / \mathrm{mL} \text { ) [197]; }\end{array}$ \\
\hline & & BMP-10 & N.A. & $\begin{array}{c}\uparrow \mathrm{pSmad} 1 / 5 \text { (human embryonic stem cells; } \\
100 \mathrm{ng} / \mathrm{mL} \text { ) [194]; } \\
\text { MAPK: } \uparrow \text { pp38 (human embryonic stem cells; } \\
100 \mathrm{ng} / \mathrm{mL} \text { ) [194]. }\end{array}$ \\
\hline $\begin{array}{l}\text { BMPRIA (ALK3); BMPRIB } \\
\text { (ALK6) }\end{array}$ & BMPRII & BMP-15 & $\begin{array}{l}\uparrow \mathrm{pSmad} 1 / 5 \text { (immortalized human granulosa } \\
\text { cells and human granulosa cell tumor cells; } \\
100 \mathrm{ng} / \mathrm{mL} \text { ) [198]; } \\
\uparrow \mathrm{pSmad} 1 / 5 \text { (rat and human granulosa cells; } \\
100 \mathrm{ng} / \mathrm{mL} \text { ) [196]. }\end{array}$ & N.A. \\
\hline $\begin{array}{l}\text { BMPRIA (ALK3); BMPRIB } \\
\text { (ALK6) }\end{array}$ & BMPRII; ActRIIA; ActRIIB & GDF-5/-6/-7 & N.A. & $\begin{array}{c}\text { MAPK: } \uparrow \text { pp38 and } \uparrow \text { pERK1/2 (chondrogenic mouse } \\
\text { carcinoma cell line ATDC5; }<10 \mathrm{ng} / \mathrm{mL} \text { and } \\
1000 \mathrm{ng} / \mathrm{mL} \text {, respectively) [199]; } \\
\text { †pSmad1/5 (C3H10T1/2 cells; Ad-GDF6) [200]; } \\
\text { MAPK: } \uparrow \text { pp38 (C3H10T1/2 cells; Ad-GDF6) [200]. }\end{array}$ \\
\hline ActRIb (ALK4) & ActRIIA; ActRIIB & GDF-8(myostatin)/-11 & $\begin{array}{l}\uparrow \mathrm{pSmad} 2 / 3 \text { (human hepatocellular carcinoma; } \\
\text { Ad-GDF11) [201] }\end{array}$ & N.A. \\
\hline ActRIb (ALK4) & ActRIIA; ActRIIB & GDF-10/BMP-3 & N.A. & $\uparrow \mathrm{pSmad}$ 2/3 (murine C2C12 cells; 100 ng/mL) [202]. \\
\hline
\end{tabular}


The signal transduction induced by the members of the TGF- $\beta$ superfamily can also depend on a third co-receptor. It does not possess any Ser/Thr kinase activity, but is able to control the ligand availability or increase the affinity between the ligand and its receptors, thus, controlling the signaling kinetics and intensity (for review see [203]). For example, the betaglycan, also known as T $\beta$ R-III can interact not only with the three TGF- $\beta$ isoforms, but also with BMP-2, BMP-4, and BMP-7 [204-206]. Another type III receptor called endoglin (ENG) appears to have affinity to TGF- $\beta 1$ and TGF- $\beta 3$ but not to TGF- $\beta 2$, despite sequence homologies with betaglycan [207]. However, these observations remain controversial since Castonguay et al., using cell-based assays and surface plasmon resonance, found that ENG fails to bind TGF- $\beta 1$ and TGF- $\beta 3$, with or without type II receptor T $\beta$ RII [208]. Nevertheless, ENG recently gained a lot of interest because of its involvement in endothelial cells response to members of the third BMP/GDF subgroup (BMP-9 and BMP-10) [209].

Six Smad proteins are known to transduce the signals of the TGF- $\beta$ members from the cell surface to the nucleus (Smad2/3, Smad1/5/(8 or 9), and Smad4). These are transcription factors that contain two highly conserved domains-the Mad homology 1 (MH1) domain at their N-terminus and the Mad homology 2 (MH2) domain at their $\mathrm{C}$ terminus, which are connected through a poor conserved linker region. The MH1 and MH2 domains play a crucial role in DNA recognition/binding and Ser/Thr receptor interaction, respectively [210,211]. The linker region, rich in Pro and Ser/Thr residues, is "structurally flexible" and possesses several phosphorylation sites that control the ability of the Smad proteins to transduce the signal into the nucleus [212-215]. 


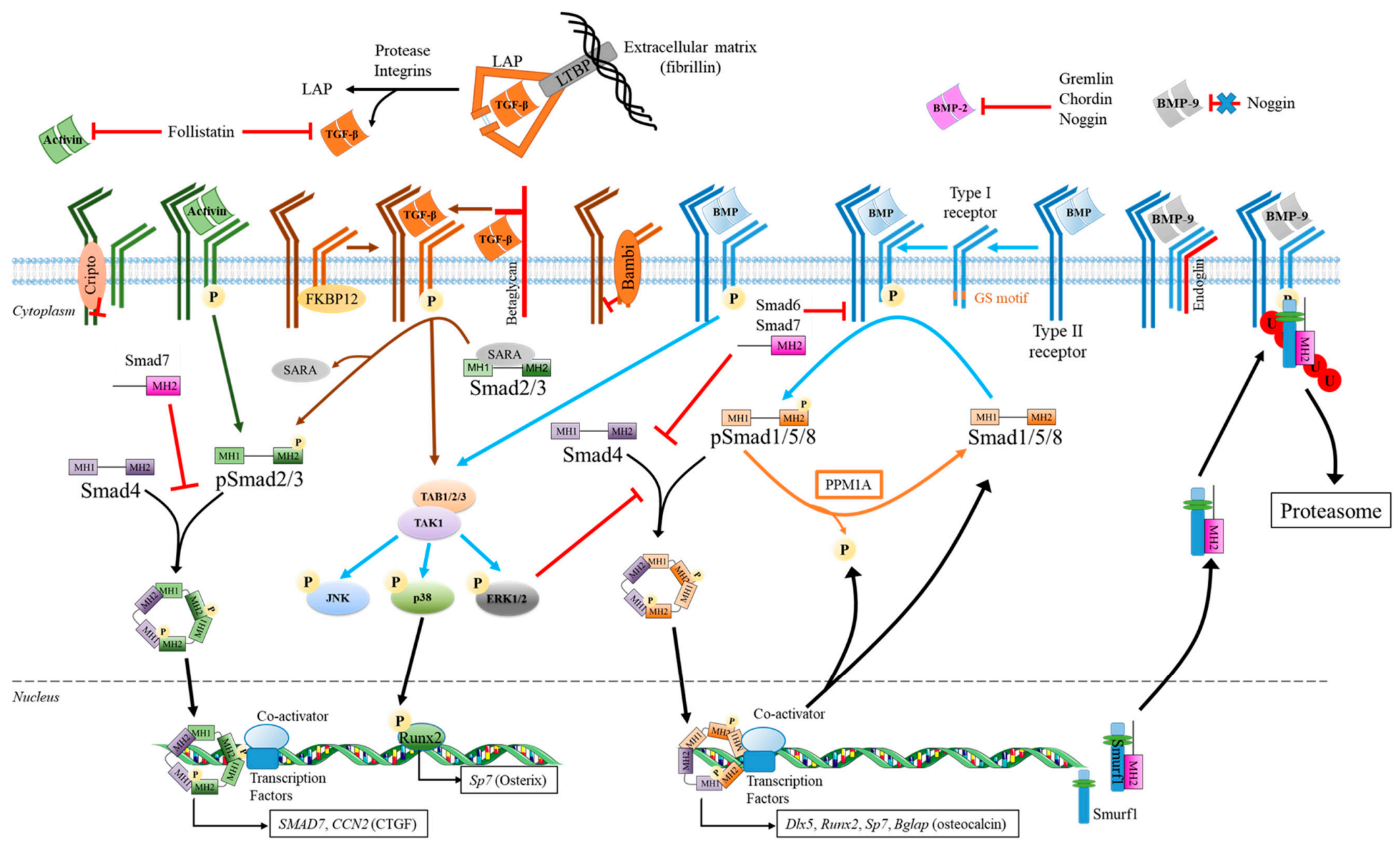

Figure 2. The TGF- $\beta$ superfamily canonical and non-canonical pathways and their regulation for controlling the expression of targeted genes in osteoprogenitors and bone forming cells [120,133,159,216-219]. BAMBI: BMP and activin membrane-bound protein; FKBP12: FK506 binding protein of 12 kDa; LAP: latency associated peptide; LTBP: Latent TGF- $\beta$ binding protein; PPM1A: protein phosphatase magnesium-dependent $1 \mathrm{~A}$; and SARA: Smad anchor for receptor activation protein. The figure was created using Servier Medical Art. https://smart.servier.com). 


\section{- $\quad$ Smad 2/3 Pathway}

The activation of the canonical Smad2/3 pathway is initiated by the recognition of the dimeric ligands (members of the TGF- $\beta$ /Nodal/Activin family and BMP/GDF subgroups V, VI, and VII) by a Type II receptor homodimer [220]. For example, all TGF- $\beta$ isoforms can specifically interact with the T $\beta$ RII receptors. However, while TGF- $\beta 1$ and TGF- $\beta 3$ bind T $\beta$ RII with a high affinity (estimated $K_{D} \sim 200 \mathrm{pM}$ and $\sim 500 \mathrm{pM}$, respectively), TGF- $\beta 2$ binds T $\beta$ RII with a low affinity (estimated $\mathrm{K}_{\mathrm{D}}>10 \mathrm{nM}$ ) [221].

The ligand-Type II receptor bindings induce a conformation change of the receptors making high affinity binding sites for Type I receptors accessible. Three type I receptors, ActRIb/ALK4, T $\beta$ RI/ALK5, and ALK7, can initiate the TGF- $\beta /$ Nodal/Activin signaling [162]. However, T $\beta$ RII transduce the TGF- $\beta$ signal exclusively by forming heterooligomers with ALK5. In the same way, ALK4 is described as the main type I receptor for activin A [222,223]. Upon their recruitment, an allosteric conformation change of the Type I receptors occurs. It allows the release of the FK506 binding protein of $12 \mathrm{kDa}$ (FKBP12) from Type I receptors. These type I receptors are then activated via the phosphorylation of their Gly/Ser rich motif (GS motif), located adjacent to their kinase domain by type II receptors [224]. Upon phosphorylation, they have a higher affinity for the MH2 domains of Smad2/3 proteins, thus promoting the Type I receptors-Smad2/3 interaction [219].

It was suggested that the specific interaction between the Type I receptors and Smad2/3 proteins are mediated via their L45 loop in the kinase domain and L3 loop in MH2 domain, respectively. However, the amino acid sequence of the L45 loop (a loop in the N-lobe of the receptor) is identical between ALK4, ALK5, and ALK7 [225,226]. The subcellular localization and presentation of Smad2/3 to type I receptors appears also to involve several proteins, such as the Smad anchor for receptor activation protein (SARA) located in early endosomes [227,228].

The type I receptors then phosphorylate the Smad2/3 proteins at 2 Ser residues ${ }^{*}$ ) in the SS ${ }^{*} \mathrm{SS}^{*}$ motif, on their MH2 domain. Phosphorylated Smad2/3 also called the receptor-regulated Smad proteins (R-Smad) can then be dissociated from the receptors and interact with the L3 loop on the MH2 domains of Smad 4 (also called Co-Smad) to form heterotrimeric complexes. In fact, Tsukazaki et al. found that phosphorylation of Smad2 induces its dissociation from SARA but favors Smad2/Smad4 interaction [227]. These R-Smad/Co-Smad complexes are translocated to the nucleus, where they interact with specific DNA sequence (Smad-binding element) via the Smad3 MH1 domains and the cooperation of other transcription factors (TFE3), to induce the transcription of specific genes (SMAD7) $[229,230]$. The ability of Smad2 to interact with DNA requires an open conformation of its E3 insert on the MH1 domain [231]. After the gene transcription, the nuclear Smad2/3-Smad 4 complexes can be dephosphorylated, dissociated from DNA, and recycled. The principal Smads in the TGF- $\beta$ /Activin/Nodal pathways lead to target genes different from those controlled by the Smads in the BMP pathways [16].

Several studies observed the activation of the Smad canonical pathway induced by TGF- $\beta 1$ in osteoclast precursors and mature osteoclasts (Table 1). For example, Gratchev et al. showed that TGF- $\beta 1(10 \mathrm{ng} / \mathrm{mL})$ induces the activation of the Smad2/3 signaling pathways after only $10 \mathrm{~min}$ of stimulation [176]. Furthermore, this stimulation is 10 times greater in mature human macrophages than in non-mature ones [176]. Activation of this signaling pathway mediates the expression of other factors that play a key role in cell differentiation. Ota et al. showed that the expression of Wnt $10 \mathrm{~b}$ factor by TGF- $\beta 1(2 \mathrm{ng} / \mathrm{mL})$ is dependent on the activation of Smad2/3 in osteoclasts but independent of other signaling pathways (Akt or MAPK) [177].

- Smad1/5/8 Pathway

The activation of the canonical Smad1/5/8 pathway is primarily initiated by the BMP homodimers (subgroups BMP subgroups I to IV) or heterodimers binding to Ser/Thr kinase receptors by their wrist epitopes (type I receptor interaction), and knuckle epitopes (Type II receptor interaction) [140,162]. In fact, when BMP dimer binding induced the receptor oligomerization, the Smad1/5/8 pathway 
is favored. In contrast, BMP dimer interaction with preassembled receptor complexes induce the MAPK pathway activation [232,233]. BMP members of the dpp, 60A, and third (BMP-9/BMP-10) subgroups bind several type II receptors (BMPRII, ActRIIA, and ActRIIB) with different affinities [234]. For example, BMP-2 has a lower affinity for ActRIIA than BMP-7 (Kd $=24 \mathrm{nM}$ for BMP-2; Kd $=8 \mathrm{nM}$ for BMP-7). The type I receptors ALK1, ALK2, ALK3 (BMPRIa), and ALK6 (BMPRIb) can also trigger the BMP signaling. For example, BMP-9 binds to ALK1 with a high affinity, but it can also transduce its signal through ALK2 $[140,235,236]$. BMP-2 and BMP-4 (dpp subgroups) are mainly recognized by ALK3 and ALK6 [234,236,237]. Interestingly, Salmon et al. recently confirmed the findings of Mi et al. showing that pro-BMP-9 complexes can also bind to ALK1 via a partial but not entire displacement of their pro-domain fragments ( $\alpha 5$-helix) [121,149]. Using surface plasmon resonance analyses, they found that the $\mathrm{K}_{\mathrm{D}}$ value of pro-BMP-9: ALK1-Fc complex (around $61 \mathrm{pM}$ ) is quite similar to that obtained with BMP-9 (around $48 \mathrm{pM}$ ) [149]. The pro-BMP-9 complexes can also selectively bind to type II Ser/Thr kinase receptors with different $\mathrm{EC}_{50}$ as compared to mature BMP-9. These complexes interact better with ActRIIB than BMPRII (EC ${ }_{50}$ for Fc-fused type II receptors of $0.02 \mathrm{nM}$ and $1.6 \mathrm{nM}$, respectively), while BMP-9 similarly binds both receptors ( $\mathrm{EC}_{50}$ for Fc-fused type II receptors of $0.04 \mathrm{nM}$ ) [121].

Upon BMP binding, the constitutively active Ser/Thr kinase type II receptors phosphorylate the type I receptors at their GS motif. The activated type I receptors in turn phosphorylate, Smad 1/5/8 on the SSXS motif, which can then interact with Smad 4 to form complexes [238]. These complexes translocate into the nucleus to regulate with other transcription factors, such as Runx2 and Osterix the expression of genes such as BGlap1 encoding osteocalcin [239].

Few studies analyzed the signaling pathway induced by BMPs in osteoclasts (Table 1) [171,187]. Our research team found that rhBMP-9 at $150 \mathrm{ng} / \mathrm{mL}$ induces the Smad1/5/8 phosphorylation at $15 \mathrm{~min}$ in human osteoclasts. The Smad1/5/8 that remain phosphorylated within $2 \mathrm{~h}$ were translocated into the nucleus. In contrast as expected, the Smad2 phosphorylation levels following rhBMP-9 stimulation are faint, compared to TGF- $\beta$ (10 ng/mL) [171]. On the other hand, Broege et al. showed that BMP-2 induces the activation of canonical (Smad) and non-canonical (MAPK) signaling pathways differently, depending on the stage of differentiation of bone marrow macrophages into osteoclasts [187]. BMP-2 at $30 \mathrm{ng} / \mathrm{mL}$ induces the activation of MAPK pathways (p38), at an early stage in pre-fusion osteoclasts (day 1 of differentiation), whereas Smad1/5/8 are phosphorylated during the fusion of osteoclast precursors (day 2-3 of differentiation) [187].

\section{- Regulation Mechanisms of the Canonical Smad Pathways}

The canonical pathways activated by members of the TGF- $\beta$ family can be inhibited by several mechanisms (Figure 3) [203]. The signal transduction induced by the members of the TGF- $\beta$ superfamily can be regulated by the internalization of the cell-surface receptors, through clathrin-dependent mechanisms or cholesterol enriched caveola [233]. Inactive membrane receptor lacking the intracellular Ser/Thr kinase domain such as BAMBI (decoy-receptor BMP and activin membrane-bound protein) can also inhibit TGF- $\beta$, activing, and BMP signaling. BAMBI appears to act through interaction with receptors rather than TGF- $\beta$ ligands, as shown by Onichtchouk et al., using a receptor affinity-labeling experiment with radiolabeled $\left[{ }^{125} \mathrm{I}\right] \mathrm{BMP}-2$ or $\left[{ }^{125} \mathrm{I}\right]$ TGF- $\beta 1$ [240]. Interestingly, they also found that BAMBI can interact with all type I receptors except ALK2, and with T $\beta$ RII and ActRII type II receptors [240]. In the same way, activin- $\beta A$ and $-\beta B$ that can signal through ALK4 and ActRIIA or ActRIIB are inhibited by the receptor Cripto-1 [241].

Another mechanism, preventing the signaling pathways of the TGF- $\beta$ superfamily, is the use of antagonist proteins such as the Dan family (Gremlin), the Spemann organizer signal molecules (Noggin, Chordin) and follistatin $[92,159,203]$. These antagonist proteins are secreted into the extracellular space and selectively bind to certain members of the TGF- $\beta$ superfamily, blocking the activation of their receptor and inhibiting the intracellular signaling $[159,203]$. The binding of Noggin and Chordin to BMP-2, BMP-4, and with lower affinity to BMP-7, prevents the recognition and interaction with their type I and type II receptors $[167,242,243]$. On the other 
hand, follistatin and follistatin-like proteins are the only secreted antagonists acting on activins, TGF- $\beta$ s, and GDF8/myostatin [244,245].

Other regulatory mechanisms act directly in the cytoplasm. The deactivation of R-Smad can be obtained via their dephosphorylation by phosphatases, such as the protein phosphatase magnesium-dependent 1A (PPM1A). The canonical Smad pathway can also be blocked by intracellular molecules like Smad 6/7, also called I-Smad (Inhibitory Smad) [246]. Unlike R-Smad and Co-Smad, I-Smad contains only one conservative MH2 domain [214]. The MH2 domains of I-Smad, particularly the L3 loop, are essential for their association with activated type I receptors [247]. Smad6 primarily interferes with the signal transduction of BMPs, through ALK3 and ALK6 [248]. For example, the binding of Smad6 on ALK3 occurs exclusively through a motif of the MH2 domain, called the basic groove, comprising the L3 loop of the MH2 domain and $\alpha$-helix 1 [249]. Smad7 uses two distinct structural motifs (the basic groove and the three-finger structure) to inhibit Smad signaling induced by TGF- $\beta$ and BMPs $[247,250]$. The basic groove of Smad-7 interacts with the ALK5 receptor [249], while both three-finger-shaped structure and basic groove, are involved in interaction with ALK2, ALK3, and ALK4 receptors [247]. Interestingly, I-Smad can cooperate with other proteins to inhibit intracellular signaling by acting on activated type I receptors. For example, they can act with the E3 ubiquitin ligase Smurf (Smad ubiquitin regulatory factor), to favor the proteasome degradation of both TGF- $\beta$ and BMP receptors upon their ubiquitination [251]. For example, BAMBI can act synergistically with Smad7 through a ternary complex with ALK5, to block the association of R-Smad (Smad3) with receptors, and their activation [203,252]. Furthermore, it was also suggested that Smad8/9 that displays a lower transcriptional activity than Smad1/5 can act as an inhibitor of BMP signaling $[253,254]$.

It was recently shown that microRNAs (miRNAs) can play a strong role in the regulation of the signal transduction induced by the members of the TGF- $\beta$ superfamily. MicroRNAs, which possess 18-25 nucleotides, are small noncoding RNA molecules that can inhibit the translation of targeted mRNAs or induce their degradation (for review see [255]). Both miR-422a and miR-153 inhibit the post transcriptional expression of the gene encoding TGF- $\beta 2$ in osteosarcoma cells [256-258]. MicroRNAs such as members of the miR-30 family (miR-30a, -30b, -30c, -30d) can also downregulate the amount of Smad1 and Runx2, when introduced in MC3T3-E1 preosteoblasts treated by $200 \mathrm{ng} / \mathrm{mL}$ BMP-2, thus, preventing osteogenesis [259]. Interestingly, among the six members of the miR-30 family (miR-30a, -30b, -30c, -30d, -30e, and miR-384-5p), only the expression of miR-30a, -30b, -30c, and -30d is downregulated in murine MC3T3-E1 preosteoblasts treated by $200 \mathrm{ng} / \mathrm{mL}$ BMP-2, after incubation for $8 \mathrm{~h} \mathrm{[259].} \mathrm{Li} \mathrm{et} \mathrm{al.} \mathrm{also} \mathrm{found} \mathrm{that} \mathrm{the} \mathrm{introduction} \mathrm{of} \mathrm{miR-135} \mathrm{and} \mathrm{miR-133} \mathrm{into} \mathrm{MC3T3-E1}$ preosteoblasts, downregulates the expression of Smad5 and Runx2, respectively, and reduces the expression of markers of osteoblast differentiation (Alkaline phosphatase, ALP) [260]. In contrast, some other miRNA can promote osteogenesis by upregulating the expression of BMP and transcription factors or preventing the expression of their BMP pathway inhibitors $[255,261]$. The overexpression of miR-20A in human MSCs isolated from bone marrow, promotes their osteogenic differentiation. It also induces an increase in BMP-2/BMP-4 and Runx2 at both mRNA and protein levels. In addition, miR-20A downregulates the expression of the membrane receptor BAMBI [261]. 


\subsubsection{Non-Canonical Pathways Used by Members of TGF- $\beta$ Superfamily}

The members of the TGF- $\beta$ superfamily through binding to their preformed type I and type II receptors can first activate XIAP, then TAK1 and TAB1, which in turn initiates the p38, ERK, and JNK (c-Jun amino (N)-terminal kinases) MAPK cascades [262-264]. For example, Li et al. found that the phosphorylation of ERK1/2 is decreased in the mouse spleen macrophage through BMP-9 treatment [265] (Table 1). In contrast, our research team showed that BMP-9 at $150 \mathrm{ng} / \mathrm{mL}$ induces an increase in the amount of phosphorylated ERK1/2, but not p38 in human osteoclast, after 5 min [171]. Moreover, Broege et al. showed that phosphorylation of p38 in murine pre-fusion osteoclasts is increased, following treatment during $15 \mathrm{~min}$ with BMP-2 (30 ng/mL) [187] (Table 1).

MAPK cascades can favor or prevent osteogenic differentiation. For example, MAPKs promote osteoprogenitor differentiation by upregulating the expression of Runx2 and Osterix [266,267]. MAPKs such as p38 and ERK1/2 can phosphorylate osteogenic transcription factors, especially Dlx5, Runx2 and Osterix, thus, promoting their activity [28,268-270]. In contrast, JNK1, by phosphorylating Runx2 at Ser104, reduces its transcriptional activity [271]. Furthermore, the MAPK pathway can also antagonize the BMP canonical Smad cascade by phosphorylating the linker region of Smad1, which inhibits Smad1 activity and might prevent its nuclear localization [215,272].

To summarize, the description of the signal transduction induced by the members of the TGF- $\beta$ superfamily can appear simple-hetero-oligomerization of limited number of Type I and Type II receptors leading to 2 canonical Smad pathways activation. However, it must be kept in mind that the ligand pro-domains, ligand heterodimerization, binding receptor affinities, structure of both ligand-receptor complexes, with or without third co-receptors, and R-Smad/Co-Smad complexes also have strong effects, which are still under investigation (for review see [203,273]). Furthermore, other signaling pathways such as the Wnt and Notch cascades, are also able to regulate the signal transduction induced by the members of the TGF- $\beta$ superfamily. 


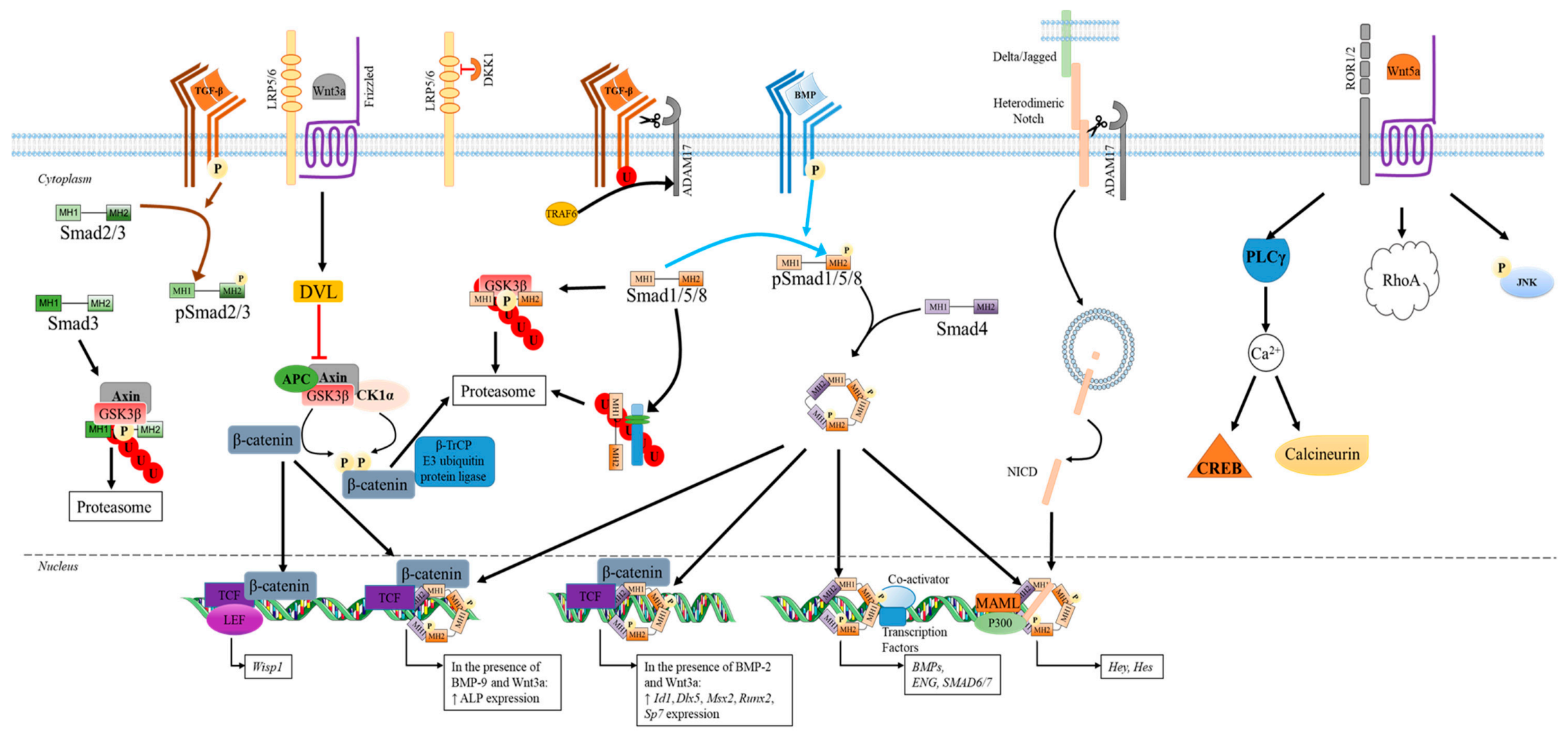

Figure 3. The effect of Wnt and Notch pathways on TGF- $\beta$ superfamily signaling to control the expression of targeted genes in osteoprogenitors and bone-forming cells [216,217,274-277]. APC: adenomatous polyposis coli; $\beta$-TrCP: $\beta$-transducin repeat-containing protein; CKI $\alpha$ : Casein kinase I $\alpha$; Dkk1: Dickkopf1; DVL: Disheveled; ENG: Endoglin; GSK3 $\beta$ : Glycogen synthase kinase-3 $\beta$; LEF: Lymphoid enhancer-binding factor; LRP5/6: low-density-lipoprotein-related protein 5/6; NICD: Notch intracellular domain; TCF: T cell factor; and U: ubiquitination. The figure was created using Servier Medical Art. https://smart.servier.com. 


\subsubsection{Other Regulators of the TGF- $\beta$ Superfamily}

- Wnt Signaling Pathways

The Wnt proteins were discovered in 1980s due to the work of Nusse and Varmus who identified the int-1 proto-oncogene in virus-induced C3H mouse mammary tumor model [278]. Indeed, the name Wnt is derived from a combination between the Drosophila segment polarity gene called wingless and its vertebrate homolog, integrated (int-1) [279]. To date, 19 genes encoding Wnt proteins are identified in mammals. The members of the Wnt family can transduce their signals inside the cells through 3 major pathways-one $\beta$-catenin dependent called the canonical Wnt pathway and two other $\beta$-catenin independent pathways, known as planar cell polarity (PCP) and $\mathrm{Wnt} / \mathrm{Ca}^{2+}$ pathways, which are considered to be non-canonical [280].

The 3 major Wnt pathways act on cells through a family of seven-pass transmembrane Frizzled (Fz) receptors, which interact with Wnt, via their extracellular N-terminal cysteine-rich domain (CRD) (for review see [281] and [282]).

\section{- Canonical Wnt pathways}

When the canonical Wnt pathway remains inactive, $\beta$-catenin forms a destruction complex with the adenomatous polyposis coli (APC), Axin, casein kinase I (CKI), and Glycogen synthase kinase-3 $\beta$ (GSK3 $\beta$ ). Then, $\beta$-catenin is phosphorylated by these kinases (CKI then GSK3) leading to its ubiquitination by $\beta$-transducin repeat-containing protein $(\beta-\operatorname{TrCP})$, an E3 ubiquitin ligase $[283,284]$. Upon ubiquitination, $\beta$-catenin is transported to the proteasome for degradation, blocking any signal transduction inside the nucleus.

The canonical Wnt pathway is initiated by the binding of Wnt, such as Wnt1 and Wnt3A, to Fz receptor and a single-span transmembrane co-receptor called low-density-lipoprotein-related protein 5/6 (LRP5/6) (Figure 3). The co-receptors LRP5/6 can interact with Disheveled (DVL), which then binds to Axin. Axin prevents the phosphorylation of $\beta$-catenin, allowing its accumulation in the cytosol. Then, $\beta$-catenin can be translocated to the nucleus, where it activates TCF (T cell factor) and LEF (lymphoid enhancer-binding factor), to induce the expression of specific genes such as Wisp-1. The Wnt pathways can be antagonized by several proteins such as the Fz-related proteins (sFRPs), which are able to bind Wnt, preventing their recognition by the receptors. Other antagonists such as the members of the Dickkopf (Dkk 1,-2 and -4) interact with LRP5/6, inhibiting the canonical Wnt pathway [285].

The canonical Wnt pathway through the $\beta$-catenin is involved in the skeletal development, as well as the fracture healing process $[286,287]$. For example, Wnt can direct the fate of mesenchymal stromal cells and favors their osteogenic differentiation by upregulating the genes encoding for the transcription factor Runx2 and Osterix, while it limits their adipogenic differentiation by preventing the expression of the genes encoding CCAAT/enhancer-binding protein alpha and PPAR- $\gamma$ [288]. In addition, $\beta$-catenin and TCF- 1 can indirectly inhibit osteoclastogenesis, by favoring the expression of the gene encoding OPG in osteoblasts [289].

The Wnt pathway activation states are, therefore, able to regulate the signaling of TGF- $\beta$ superfamily members and vice-versa $[217,290,291]$. For example, Guo et al. showed that unlike Smad2, the availability of Smad3 for type I receptor activation can be controlled by Axin and GSK3 $\beta$. Indeed, Smad3 forms a destruction complex with Axin and GSK3 $\beta$, independent of the $\beta$-catenin, allowing its phosphorylation at Thr66 by the kinase, its subsequent ubiquitination, and proteasome-dependent degradation. Furthermore, Axin depletion enhances Smad 3 activation by TGF- $\beta$ [292]. Fuentealba et al. also observed that Smad1 phosphorylation at its linker region by GSK3 leading to its polyubiquitination, is dependent on ERK prephosphorylation [293]. The activation of the Wnt pathways by Wnt3a stabilizes Smad1 by preventing its phosphorylation by GSK3 [293].

Some Wnt ligands can also promote a shift of the TGF- $\beta$ signaling pathway from Smad2/3 towards Smad1/5/8. Using murine P2 chondrocytes, Van den Bosch et al. found that a Wnt3a $(300 \mathrm{ng} / \mathrm{mL})$ pretreatment is enough to decrease the amount of phosphorylated Smad2/3 induced by TGF-B1 
( $5 \mathrm{ng} / \mathrm{mL}$ ) for $30 \mathrm{~min}$. In contrast, it increases the amount of phosphorylated Smad1/5/8, signaling involved in chondrocyte hypertrophy. Similar results were obtained with human G6 chondrocytes, and the effect on the shift in TGF- $\beta$-induced Smad phosphorylation is even stronger when Wnt3a is combined with WISP [164]. The addition of a specific inhibitor of the canonical Wnt pathway (Dkk-1) in vitro, as well as the use of Wnt8a in vivo, confirmed that this shift in TGF- $\beta$-induced Smad phosphorylation depends on the canonical Wnt pathway [164].

Several studies showed that the osteoblastic differentiation of osteoprogenitor cells can also be enhanced by some BMP and Wnt combination [294-296]. For example, murine C2C12 cells treated for $2 \mathrm{~h}$ by BMP-2 $(2 \mathrm{nM})$ and Wnt3a $(100 \mathrm{ng} / \mathrm{mL})$ contained more mRNA encoding osteogenic markers Dlx5, Msx2, and Runx2 than those treated by BMP-2 or Wnt3a alone. These results were confirmed using primary mesenchymal stromal cells extracted from the bone marrow and cultured for 4 days in an osteogenic medium containing both BMP-2 and Wnt3a. The expression of genes encoding Id1, Dlx5, Msx2, Runx2, and Osterix, is synergistically increased by the cytokine combination. This synergistic effect is allowed by the formation of a cooperative Smad/TCF4/ $\beta$-catenin transcriptional complex [295]. In the same way, using murine multipotent $\mathrm{C} 3 \mathrm{H} 10 \mathrm{~T} 1 / 2$ cells infected by adenovirus (Ad) expressing BMP-9 or Wnt3a, Tang et al. found that Wnt3a enhances the BMP-9-induced ALP activity in a $\beta$-catenin dependent manner. The use of AdBMP-9 also appears to favor the expression of the late osteoblastic differentiation marker osteocalcin, through the formation of a Runx $2 / \beta$-catenin/TCF transcriptional complex. The ectopic bone formation induced by the implantation of C3H10T1/2 cells transduced with AdBMP-9 in the flanks of athymic nude mice for 5 weeks, is also inhibited by $\beta$-catenin knockdown [294].

- Non-canonical Wnt signaling pathways

The PCP pathway implies the binding of Wnt such as Wnt5A to Fz or ROR/PTK7 co-receptors, to activate JNK and members of the small Rho GTPase family like RhoA and Rac1 [297]. The signal is transduced to the nucleus, activating the expression of targeted genes like XPAPC (Xenopus paraxial protocadherin) via some transcription factors like ATF2 [298]. It was shown that bone-marrow-derived macrophages (BMMs) secrete Wnt5a that can bind to their Ror2 receptors to promote RANKL expression, leading to their differentiation into mature osteoclasts. In addition, Wnt5a-Ror2 binding on mature osteoclasts stimulates RhoA involved in the actin ring formation in osteoclasts. It also promotes the activity of the C-Src/ Rho effector kinase (Pkn3) complex, increasing osteoclast bone-resorption activity [299]. Using osteoclast specific Ror2 conditional knockout mice, Uehara et al. observed an increase in bone mass due to altered actin ring formation and bone resorption [300].

The Wnt/Ca ${ }^{2+}$ pathway involves Fz-mediated phospholipase C (PLC) activation via heterotrimeric $G$ proteins. PLC in turn catalyzes the diacylglycerol (DAG) and inositol-1,4,5-trisphosphate (IP3) production [301]. IP3 induces the $\mathrm{Ca}^{2+}$ release from intracellular endoplasmic reticulum to stimulate effectors such as calmodulin-dependent kinase II (CAMKII) and protein kinase C (PKC), which can activate, for example, the transcription factors NFKB and CREB (cyclic AMP response element-binding protein). $\mathrm{Ca}^{2+}$ and calcineurin can also activate the NFAT [302,303].

\section{- Notch Signaling Pathways}

Notch are cell-surface receptors (Notch 1-4 in mammals) that recognize Delta-like (DLL1, 3, and 4 in mammals) and Jagged (JAG1, 2 in mammals) single-pass transmembrane ligands on neighboring cells. The ligand-Notch receptor binding induces the intracellular cleavage of Notch by the TNF $\alpha$-converting enzyme (TACE) or ADAM17 and $\gamma$-secretase complex. ADAM17 belongs to the ADAM (a disintegrin and metalloproteinase) family of proteins, which are transmembrane metalloproteinases, possessing a catalytic extracellular domain, and are involved in ectodomain shedding of various cell surface proteins, including growth factors, cytokines, receptors, and adhesion molecules [304]. The T $\beta R 1$ receptor (ALK5) was previously shown to be a substrate of ADAM17, and inhibition of the activity or expression of this enzyme increased the surface expression levels of T $\beta R 1$, as well as TGF $\beta$-induced Smad 3 and 
Akt activation [305]. ADAM17, via the shedding of the T $\beta R 1$ ectodomain, is therefore, a negative regulator of TGF $\beta$-signaling.

The intracellular cleavage of Notch induces the release of NICD (notch intracellular domain), which can then be translocated to the nucleus. Afterwards, NICD interact with a DNA-binding adaptor $\mathrm{CBF} 1 / \mathrm{RBPjk} / \mathrm{Su}(\mathrm{H}) / \mathrm{Lag} 1$, called CSL, to form a transcriptional activator complex [306]. This complex also recruits the adaptor protein Mastermind-like (MAML) and histone acetyltransferases HAT p300, favoring the chromatin opening and the activation of genes such as those encoding the hairy enhancer of split (HES) and HES-related with the YRPW motif (HEY). The half-life of NICD is controlled by its phosphorylation by cyclin-dependent kinase 8 (CDK8) and subsequent ubiquitination by E3 ubiquitin ligases, leading to its proteasome degradation $[307,308]$.

Notch receptors, as well as their ligands, can be expressed in bone-forming cells and bone-resorbing cells [309-312]. For example, using flow cytometry analyses, Sekine et al. found that the Notch1 and Notch 2 receptors are expressed in human osteoclast precursors (adherent cells isolated from human peripheral blood mononuclear cells), while Notch3 expression requires M-CSF (50 ng/mL) pre-treatment for 3 days. The expression of Notch1, Notch2, and Notch3 is maintained during the osteoclast differentiation process [311]. However, a low level of their ligand DLL1 protein is observed in osteoclast precursors, after stimulation by RANKL for 3 days, while JAG1 is constitutively expressed [311].

The role played by Notch in both osteoclastogenesis, as well as osteoblast differentiation, remains controversial due to discrepancy in the results obtained by several studies due to the experimental design, cell source, and operating conditions [311,313-315].

For example, Yamada et al. found that osteoclastogenesis, as shown by the TRAP positive cells, is decreased when precursors from the bone marrow, spleen, and peritoneal cavity are cultured on plates coated with human DLL1 for 6 days, with RANKL $(25 \mathrm{ng} / \mathrm{mL})$ and M-CSF $(50 \mathrm{ng} / \mathrm{mL})$. This inhibition depends on the tissue source of the osteoclast precursors varying from $23 \%$ to $100 \%$ for the bone marrow and the peritoneal cavity, respectively [313]. In contrast, Sekine et al. observed that blockade of DLL1 with specific antibodies inhibits osteoclastogenesis of both murine (bone marrow) and human (peripheral blood mononuclear cells) osteoclast precursors [311]. In fact, these apparent discrepancies can be due to the biphasic role of the Notch pathway in osteoclastogenesis and osteoclast maturation [310]. Indeed, Ashley et al. found that early activation of the Notch pathway in murine osteoclast precursors can suppress osteoclastogenesis, while Notch enhances the maturation and function of the committed osteoclast precursors [310]. Interestingly, inhibition of Notch in the murine myeloid lineage via a dominant negative MAML reduces the osteoclast function both in vitro and in vivo. However, it does not affect the osteoblast-osteoclast coordinated activity, which might help develop a promising therapeutic approach in fracture healing [316].

Several studies also highlighted the favoring role of the Notch pathway in osteoblast differentiation induced by BMPs [312,317], while others found a synergistic Notch/BMP effect on proliferation of multipotent progenitors [275]. For example, Cao et al. recently found that murine C2C12 myoblasts cultured in BMP-9 conditioned medium (collected $48 \mathrm{~h}$ after infection of HCT116 cells by Ad-BMP9) had less Bglap transcripts (Osteocalcin) in the presence of the Notch pathway inhibitors (Ad-dominant negative Notch1 and DAPT, $\gamma$-secretase inhibitor), as compared to BMP-9 alone [317]. The cell treatment by Ad-DLL1 for $36 \mathrm{~h}$ also enhances the level of phosphorylated Smad1/5/8 induced by BMP-9 conditioned medium in both $\mathrm{C} 3 \mathrm{H} 10 \mathrm{~T} 1 / 2$ cells and C2C12 myoblasts. In fact, DLL1 might control BMP-9-induced osteoblastic differentiation through regulation of ALK2 expression [317]. In contrast, Wang et al. found that NICD overexpression inhibits the osteoblastic differentiation of C3H10T1/2 cells induced by AdBMP-9. NICD overexpression does not affect the levels of both total and phosphorylated Smad1/5/8, while it induces the suppression of JunB mRNA and protein [275]. 


\section{Effect of TGF- $\beta$ Superfamily on Bone Homeostasis and Disease}

\subsection{The Role Played by Members of TGF- $\beta$ on Osteoblast and Osteoclast Differentiation}

\subsubsection{Osteogenic Differentiation}

The members of the TGF- $\beta$ superfamily play a crucial role in the balance between bone formation and resorption. Indeed, the ability of the members of the TGF- $\beta$ superfamily, especially BMPs such as BMP-2, BMP-4, BMP-6, BMP-7, and BMP-9, to induce the osteogenic differentiation of MSCs in vitro and bone formation in vivo is well documented [150,151,153,154]. However, the treatment of MSCs from various species by BMPs can be performed using AdBMPs, chemically modified ribonucleic acids, or human recombinant (rh) BMPs, rendering the comparison of the experimental data difficult [151,318,319].

Interestingly, several studies observed a higher osteogenic potential for BMP heterodimer compared to homodimer [320-323]. For example, rhBMP-2/BMP-7 heterodimer (rhBMP2/7) at a low-dose (5-50 ng/mL) drastically enhanced the differentiation of murine MC3T3-E1 preosteoblasts into mature osteoblasts, compared to rhBMP-2 or rhBMP-7 homodimer alone. The mineralization induced by rhBMP2/7 at $50 \mathrm{ng} / \mathrm{mL}$ is around 10 - and 35-fold higher than that induced by rhBMP-2 and rhBMP-7, respectively, as shown by the alizarin red staining of the calcium deposition at 4 weeks [320]. Zhang et al. recently observed that rhBMP-2/7 at $50 \mathrm{ng} / \mathrm{mL}$ induces a higher deposition of calcium, as shown by the alizarin red staining, than rhBMP-2 and rhBMP-7 in MC3T3-E1 preosteoblasts, after incubation for 3 weeks. However, in this study, the BMP heterodimer and homodimers were added to an osteogenic differentiation medium containing $100 \mathrm{nM}$ dexamethasone, $0.2 \mathrm{mM}$ ascorbic acid, and $10 \mathrm{mM}$ beta-glycerophosphate. rhBMP-2/7 also induced a similar mineralization than both homodimers in human adipose stem cells, suggesting a "cell-specific pattern" of BMP heterodimer efficiency [324]. In addition, collagen sponges with $3 \mu \mathrm{g}$ rhBMP-2/7 implanted in dorsal muscles of rat,

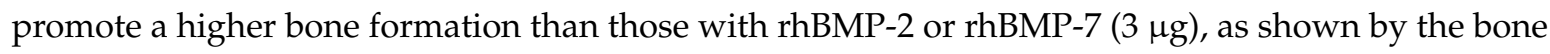
volume (microCT):T2 high volume (MRI) ratio [322].

\subsubsection{Osteoclastogenesis}

The member of the TGF- $\beta$ family can act on osteoclast progenitor proliferation, osteoclastogenesis, bone resorption activity, as well as survival of mature osteoclasts through direct or indirect (via osteoblast/osteocytes secreted factors) mechanisms (Table 2) [59,171,325].

It was shown that BMP-9 $(50 \mathrm{ng} / \mathrm{mL})$ alone can increase the proliferation of mouse spleen macrophages after 3 days [265]. However, BMPs can also promote RANKL-induced osteoclast progenitor proliferation. For example, in the presence of rhRANKL $(50 \mathrm{ng} / \mathrm{mL})$, both rhBMP-2 and rhBMP-7 (from 5 to $200 \mathrm{ng} / \mathrm{mL}$ ) increase the proliferation of RAW264.7 cells after 3 days, compared to the cells treated with rhRANKL alone [326]. 
Table 2. Effect of the member of TGF- $\beta$ superfamily on osteoclast differentiation and function.

\begin{tabular}{|c|c|c|c|c|}
\hline $\begin{array}{l}\text { Members of } \\
\text { TGF- } \beta \\
\text { Superfamily }\end{array}$ & Experimental Conditions & Impact on Gene and Protein Expression & Impact on Osteoclast Function & Refs \\
\hline \multirow{7}{*}{ TGF- $\beta 1$} & & TGF- $\beta /$ Nodal/Activin family & & \\
\hline & $\begin{array}{l}\text { Cells: Murine RAW264.7; Treatment: M-CSF } \\
(20 \mathrm{ng} / \mathrm{mL}), \text { RANK-L ( } 50 \mathrm{ng} / \mathrm{mL}) \text { and TGF- } \beta 1 \text { (0.1 to } \\
20 \mathrm{ng} / \mathrm{mL}) ; \text { Time: } 2-7 \text { days }\end{array}$ & $\begin{array}{c}\text { TGF- } \beta 1 \text { dose dependently } \uparrow \text { TNFRSF11A (RANK) } \\
\text { at } 48 \mathrm{~h} \\
\text { TGF- } \beta 15 \mathrm{ng} / \mathrm{mL} \uparrow \text { RANK protein amount after } 3 \text { days } \\
\text { TGF- } \beta 1 \text { dose dependently } \uparrow \text { both CTR and VTR } \\
\text { mRNA levels at day } 7\end{array}$ & $\begin{array}{l}\text { TGF- } \beta 1 \text { dose dependently } \uparrow \text { number of TRAP+ } \\
\text { multinucleated cells (plateau at } 1 \mathrm{ng} / \mathrm{mL} \text { ) }\end{array}$ & [327] \\
\hline & $\begin{array}{l}\text { Cells: murine primary osteoblasts co-cultured with } \\
\text { spleen cells; Treatment: } 1,25(\mathrm{OH}) 2 \mathrm{D} 3(10 \mathrm{nM}) \text { plus Dex } \\
(100 \mathrm{nM}) \text { with or without rhTGF- } \beta 1(0.3 \text { to } 10 \mathrm{ng} / \mathrm{mL}) \\
\text { M-CSF ((25 ng/mL), RANKL (50-200 ng/mL); } \\
\text { Time: } 7 \text { days }\end{array}$ & N.A. & $\begin{array}{c}\text { TGF- } \beta 1 \text { dose-dependently } \downarrow \text { osteoclast formation } \\
\text { (TRAP+ cells) in the presence of } 1,25(\mathrm{OH}) 2 \mathrm{D} 3 \\
\text { plus dexamethasone. } \\
\text { TGF- } \beta 1 \text { dose-dependently } \uparrow \text { RANKL-induced } \\
\text { osteoclastogenesis (TRAP+ cells) of M-CSF stimulated } \\
\text { spleen cells cultured alone. } \\
\text { RANKL/TGF- } \beta \text { effect is inhibited by OPG (100 ng/mL). }\end{array}$ & [328] \\
\hline & $\begin{array}{l}\text { Cells: Marrow-derived osteoclasts precursors } \\
\text { co-cultured with ST2 stromal cells; Treatment: TGF- } \beta 1 \\
\left(2 \times 10^{-5} \text { to } 2 \mathrm{ng} / \mathrm{mL}\right)\end{array}$ & N.A. & $\begin{array}{c}\text { Biphasic effect of TGF- } \beta 1 \text { on osteoclast differentiation: } \\
\uparrow \text { number of TRAP+ multinucleated cells at } \\
1 \times 10^{-4} \mathrm{ng} / \mathrm{mL} \\
\text { Complete inhibition at } 2 \mathrm{ng} / \mathrm{mL}\end{array}$ & [329] \\
\hline & $\begin{array}{l}\text { Cells: marrow and spleen cells (osteoclast precursors); } \\
\text { Treatment: ascorbic acid }\left(7 \times 10^{-3} \mathrm{M}\right) \text { and TGF- } \beta 1 \\
\left(2 \times 10^{-5} \text { or } 1 \mathrm{ng} / \mathrm{mL}\right), \mathrm{M}-\mathrm{CSF}(25 \mathrm{ng} / \mathrm{mL}) \text { and RANKL } \\
(30 \mathrm{ng} / \mathrm{mL})\end{array}$ & N.A. & $\begin{array}{c}\text { Only TGF- } \beta 1 \text { at } 1 \mathrm{ng} / \mathrm{mL} \uparrow \text { number of TRAP+ } \\
\text { multinucleated cells (spleen cells). } \\
\text { TGF- } \beta 1 \text { dose dependently } \uparrow \text { number of TRAP+ } \\
\text { multinucleated cells (marrow cells) }\end{array}$ & \\
\hline & $\begin{array}{l}\text { Cells: human mononuclear leukocytes from umbilical } \\
\text { cord blood differentiated in osteoclasts; Treatment: } \\
\text { rhTGF-1 (0.1-1 ng/mL) }\end{array}$ & $\begin{array}{l}\text { TGF- } \beta 1 \uparrow p \text { ERK } 1 / 2 \text {, phosphorylated p38 and pSmad } 2 \\
\text { TGF- } 1 \uparrow \text { amount of pro-apoptotic proteins (Bax/Bim). } \\
\text { TGF- } \beta 1 \uparrow \text { expression of Bim through Smad } 2 .\end{array}$ & $\begin{array}{l}\text { TGF- } \beta 1 \text { dose-dependently } \uparrow \text { apoptosis of human } \\
\text { osteoclasts through caspase } 9\end{array}$ & [330] \\
\hline & $\begin{array}{l}\text { Cells: monocytes from normal human peripheral blood; } \\
\text { Treatment: } 20 \mathrm{ng} / \mathrm{mL} \text { M-CSF for } 2 \text { days and then } \\
\text { RANKL }(40 \mathrm{ng} / \mathrm{mL}) \text { for an additional } 6 \text { days with or } \\
\text { without TGF- } \beta 1(10 \mathrm{ng} / \mathrm{mL}) \text {; Time: } 8 \text { days }\end{array}$ & $\begin{array}{c}\text { In the presence of M-CSF/RANKL: } \\
\text { TGF- } \beta 1 \uparrow \text { Endoglin expression (mRNA and protein) } \\
\text { compared to M-CSF/RANKL control. } \\
\text { TGF- } \beta 1 \downarrow \text { levels of mRNA encoding NFAT-c1, TRAP } \\
\text { and Cathepsin K. } \\
\text { TGF- } \beta 1 \downarrow \text { levels of mRNA encoding RANK and } \\
\text { MMP-9 through Smad1 activation }\end{array}$ & $\begin{array}{c}\text { In the presence of M-CSF/RANKL: } \\
\text { TGF- } \beta 1 \downarrow \text { number of TRAP+ multinucleated cells in a } \\
\text { Smad1 dependent manner } \\
\text { TGF- } \beta 1 \text { inhibits osteoclastogenesis only when added } \\
\text { within } 48 \mathrm{~h} \\
\text { TGF- } \beta 1 \text { †osteoclastogenesis through a Smad3 } \\
\text { dependent manner }\end{array}$ & [325] \\
\hline TGF- $\beta 2$ & $\begin{array}{l}\text { Cells: marrow and spleen cells; Treatment: ascorbic } \\
\text { acid and TGF- } \beta 2\left(2 \times 10^{-5} \text { to } 2 \mathrm{ng} / \mathrm{mL}\right) \text { with or without } \\
\text { M-CSF }(25 \mathrm{ng} / \mathrm{mL}), \text { RANKL ( } 30 \mathrm{ng} / \mathrm{mL}) \text {. }\end{array}$ & N.A. & $\begin{array}{c}\text { TGF- } \beta 2 \text { biphasic effect on osteoclast differentiation: } \\
\text { A maximal number of TRAP+ multinucleated cells at } 2 \\
\times 10^{-4} \mathrm{ng} / \mathrm{mL} \\
\text { No TRAP }+ \text { cells at } 2 \mathrm{ng} / \mathrm{mL}\end{array}$ & [329] \\
\hline Activin A & $\begin{array}{l}\text { Cells: murine bone marrow cells (BMC); Treatment: } \\
\text { rhM-CSF }(20 \mathrm{ng} / \mathrm{mL}) \text { and rhRANKL ( } 40 \mathrm{ng} / \mathrm{mL}) \text { with or } \\
\text { without rh activinA ( } 50 \mathrm{ng} / \mathrm{mL}) \text {; Time: } 4 \text { days } \\
\text { Cells: Murine monocyte/macrophage cell line } \\
\text { RAW264.7; Treatment: rhRANKL ( } 40 \mathrm{ng} / \mathrm{mL}) \text { with or } \\
\text { without rh activinA }(50 \mathrm{ng} / \mathrm{mL}) ; \text { Time: } 2,3,4 \text { or } 7 \text { days }\end{array}$ & $\begin{array}{c}\text { ActivinA } \uparrow \text { RANKL-induced NFATc1 expression in } \\
\text { both BMC and RAW264.7 via Smad2 phosphorylation } \\
\text { ActivinA } \uparrow \text { RANKL-induced osteoclastogenic gene } \\
\text { (TRAP, OC-STAMP and Cathepsin K) expression in } \\
\text { RAW264.7 at } 3 \text { days }\end{array}$ & $\begin{array}{l}\text { ActivinA } \uparrow \text { differentiation of both BMC and RAW } 264.7 \\
\text { in osteoclasts (as shown by TRAP+ cells at } 4 \text { and } 7 \text { days, } \\
\text { respectively) in the presence of M-CSF and RANKL }\end{array}$ & [184] \\
\hline
\end{tabular}


Table 2. Cont.

\begin{tabular}{|c|c|c|c|c|}
\hline $\begin{array}{l}\text { Members of } \\
\text { TGF- } \beta \\
\text { Superfamily }\end{array}$ & Experimental Conditions & Impact on Gene and Protein Expression & Impact on Osteoclast Function & Refs \\
\hline \multicolumn{5}{|c|}{ BMP/GDF family } \\
\hline BMP-2 & $\begin{array}{l}\text { Cells: murine primary osteoclast; Treatment: } 10 \mathrm{ng} / \mathrm{mL} \\
\text { of M-CSF for } 3 \text { days before adding } 30 \mathrm{ng} / \mathrm{mL} \text { of RANKL } \\
\text { with or without BMP- } 2(30 \mathrm{ng} / \mathrm{mL}) \text { for } 5 \text { days }\end{array}$ & $\begin{array}{l}\text { BMP-2 } \uparrow \text { RANKL-induced genes encoding osteoclast } \\
\text { markers (NFATc1, TRAP, DC-STAMP, cathepsin K and } \\
\text { ATP6v0d2) at day } 3 \\
\text { BMP-2 plus RANKL had no effect on RANKL or OPG } \\
\text { expression at day } 3\end{array}$ & $\begin{array}{l}\text { BMP-2 from day } 3 \text { to day } 4 \uparrow \text { RANKL-induced osteoclast } \\
\text { formation as shown by an increase in TRAP+ } \\
\text { multinuclear cells } \\
\text { Suppression of BMPRII expression by specific shRNA } \\
\text { inhibits osteoclastogenesis }\end{array}$ & [331] \\
\hline BMP-2 & \multirow[t]{2}{*}{$\begin{array}{l}\text { Cells: bone marrow mononuclear cells incubated } \\
\text { Treatment: } 20 \mathrm{ng} / \mathrm{mL} \text { of M-CSF for } 4 \text { days, followed by } \\
\text { another } 5 \text { days with } 20 \mathrm{ng} / \mathrm{mL} \text { M-CSF and } 50 \mathrm{ng} / \mathrm{mL} \text { of } \\
\text { RANKL with or without BMP- } 2 \text { or BMP- } 7 \text { at } 100 \mathrm{ng} / \mathrm{mL} \text {. }\end{array}$} & $\begin{array}{l}\text { BMP- } 2 \uparrow \text { the amount of pSmad1/5/9 through ALK2 and } \\
\text { ALK3 } \\
\text { BMP-2 via Smad activation } \uparrow \text { NFATc1 protein levels } \\
\text { and its nuclear translocation in osteoclasts }\end{array}$ & $\begin{array}{c}\text { BMP-2 alone had no effect on osteoclast differentiation } \\
\text { BMP-2 } \uparrow \text { RANKL-induced osteoclastogenesis as shown } \\
\text { by TRAP+ cells (with three or more nuclei) at day } 5 \\
\text { BMP-2 plus RANKL } \uparrow \text { the area of demineralized pits on } \\
\text { OsteoAssay surface plates }\end{array}$ & [59] \\
\hline BMP-7 & & $\begin{array}{l}\text { BMP-7 } \uparrow \text { the amount of } \mathrm{pSmad} 1 / 5 / 9 \text { through ALK2 } \\
\text { BMP-7 via Smad activation } \uparrow \text { NFATc1 protein levels } \\
\text { and its nuclear translocation in osteoclasts }\end{array}$ & $\begin{array}{c}\text { BMP-7 alone had no effect on osteoclast differentiation } \\
\text { BMP-7 } \uparrow \text { RANKL-induced osteoclast differentiation at } \\
\text { day } 5 \\
\text { BMP-7 plus RANKL } \uparrow \text { demineralization activity }\end{array}$ & \\
\hline BMP-9 & $\begin{array}{l}\text { Cells: human mononuclear leukocytes from umbilical } \\
\text { cord blood are differentiated in osteoclasts; Treatment: } \\
\text { Opti-MEM media supplemented with } 2 \% \mathrm{FBS}, 25 \mathrm{ng} / \mathrm{mL} \\
\text { M-CSF and } 100 \mathrm{ng} / \mathrm{mL} \text { of RANKL with or without } \\
\text { BMP-9 (50 or } 150 \mathrm{ng} / \mathrm{mL})\end{array}$ & $\begin{array}{l}\text { BMP-9 acts via BMPR-II receptor to activate } \\
\text { ERK1/2 pathways } \\
\downarrow \text { of BMPR-II by siRNA prevents bone resorption }\end{array}$ & $\begin{array}{c}\text { In the presence of M-CSF/RANKL: } \\
\text { No effect of BMP-9 on osteoclast formation (no change } \\
\text { in \% of multinucleated cells expressing RANK or CTR) } \\
\text { BMP-9 } \uparrow \text { bone resorption (30-40\%) } \\
\text { BMP-9 }(50 \mathrm{ng} / \mathrm{mL} \text { ) protects osteoclasts from apoptosis by } \\
\downarrow \text { the } \% \text { of cleaved caspase } 9 \text { and its activity }\end{array}$ & [171] \\
\hline Myostatin & $\begin{array}{l}\text { Cells: Bone marrow-derived macrophages Treatment: } \\
50 \mathrm{ng} / \mathrm{mL} \text { M-CSF for } 72 \mathrm{~h} \text {. Then cells are incubated for } \\
4-6 \text { days with M-CSF }(50 \mathrm{ng} / \mathrm{mL} \text { ) and RANKL }(50 \\
\text { ng/mL) with or without myostatin }(30 \mathrm{ng} / \mathrm{mL})\end{array}$ & $\begin{array}{l}\text { Myostatin } \uparrow \text { RANKL-induced expression of NFATc1; } \\
\text { integrin } \alpha \text {, integrin } \beta 3 \text {, DC-STAMP and CTR } \\
\text { Myostatin activates Smad2 to enhance } \\
\text { RANKL-induced osteoclastogenesis } \\
\text { NFATC1 and pSmad2 can interact together favoring } \\
\text { their nuclear translocation }\end{array}$ & $\begin{array}{l}\text { No effect of Myostatin alone on osteoclast formation, } \\
\text { apoptosis, and proliferation } \\
\text { Myostatin + M-CSF/RANKL } \uparrow \text { osteoclastogenesis } \\
\text { (3.8-fold more osteoclasts after } 4 \text { days compared with } \\
\text { M-CSF/RANKL control) } \\
\text { ALK4/ALK5/ALK7 inhibitor } \downarrow \text { number of osteoclasts }\end{array}$ & [332] \\
\hline
\end{tabular}

$\downarrow$ : Decrease; $\uparrow:$ Increase; N.A.: Not available. 
Furthermore, several studies showed that some members of the TGF- $\beta$ superfamily promote RANKL-induced osteoclast differentiation (Table 2). For example, Itoh et al. found that RANKL is required to observe any osteoclast differentiation of mouse bone marrow macrophages in the presence of rhBMP-2 (300 ng/mL), since adding rhOPG prevents osteoclastogenesis [333]. In the same way, both rhBMP-2 and rhBMP-7 favor the osteoclastogenesis of the RAW264.7 cells in the presence of rhRANKL ( $50 \mathrm{ng} / \mathrm{mL})$. However, while rhBMP-2 $(5-150 \mathrm{ng} / \mathrm{mL})$, in the presence of RANKL, dose dependently increases the calcium phosphate resorption area compared to rhRANKL alone, rhBMP-7 induces less bone resorption at $150 \mathrm{ng} / \mathrm{mL}$ than at $5 \mathrm{ng} / \mathrm{mL}$, after 7 days [326].

The rhBMP-2/7 heterodimers (5-150 ng/mL) also enhance the RANKL-mediated osteoclastogenesis [326]. The same observation was done using rhBMP-9, the cytokine at doses varying from 50 to $150 \mathrm{ng} / \mathrm{mL}$, enhanced the osteoclast differentiation of mouse spleen macrophages induced by rhRANKL (100 ng/mL) [265]. The authors suggested that BMP-9 inhibits the intracellular ERK1/2 pathways to favor the osteoclastogenesis [265]. Using human mononuclear macrophages from umbilical cord, our research team also found that rhBMP-9 $(50$ and $150 \mathrm{ng} / \mathrm{mL})$ in the presence of both rhM-CSF $(25 \mathrm{ng} / \mathrm{mL})$ and rhRANKL $(100 \mathrm{ng} / \mathrm{mL})$, significantly increases the bone resorption (around 40\%) compared to the control. Nevertheless, this effect is not due to an increase in mature osteoclast formation, but an inhibition of their apoptosis [171]. Indeed, BMPs can also act on mature osteoclast function. Using mature osteoclasts purified (>99\%) from rabbit bones, Kaneko et al. also found that among rhTGF- $\beta$, rhBMP-2, and rhBMP-4 $(1,10,100 \mathrm{ng} / \mathrm{mL})$, only rhBMP-2 and rhBMP-4 directly and dose dependently enhance the osteoclastic bone resorption after incubation for $18 \mathrm{~h}$. This effect is not due to a change in the number of osteoclasts on dentine slices. In addition, rhBMP-2 at $100 \mathrm{ng} / \mathrm{mL}$ increases the mRNA levels of both cathepsin K and carbonic anhydrase II [172].

Some members of the TGF- $\beta$ superfamily can also inhibit osteoclastogenesis [329]. Using marrow-derived osteoclasts precursors and ST2 stromal cells co-cultures, Karst et al. found that both TGF- $\beta 1$ and TGF- $\beta 2$ have a biphasic effect on osteoclast differentiation, increasing it at low concentration $\left(1 \times 10^{-4}\right.$ or $\left.2 \times 10^{-4} \mathrm{ng} / \mathrm{mL}\right)$, while completely preventing it at high concentration $(2 \mathrm{ng} / \mathrm{mL})$ [329].

Lee et al. also recently found that TGF- $\beta 1(0.1,1,10 \mathrm{ng} / \mathrm{mL})$ dose-dependently decreases the number of TRAP-positive multinucleated cells incubated for 2 days with $20 \mathrm{ng} / \mathrm{mL} \mathrm{M-CSF}$ and then $40 \mathrm{ng} / \mathrm{mL}$ RANKL for 6 days [325]. However, TGF- $\beta 1$ inhibits osteoclastogenesis only when added at the early stages of differentiation, within $48 \mathrm{~h}$. It also decreases the mRNA levels of NFAT-C1, TRAP and Cathepsin K. Interestingly, TGF- $\beta 1$ through Smad3 stimulation, favors RANK expression in human osteoclast precursors, while TGF- $\beta 1$ through Smad1, suppresses it [325] (Figure 4). 


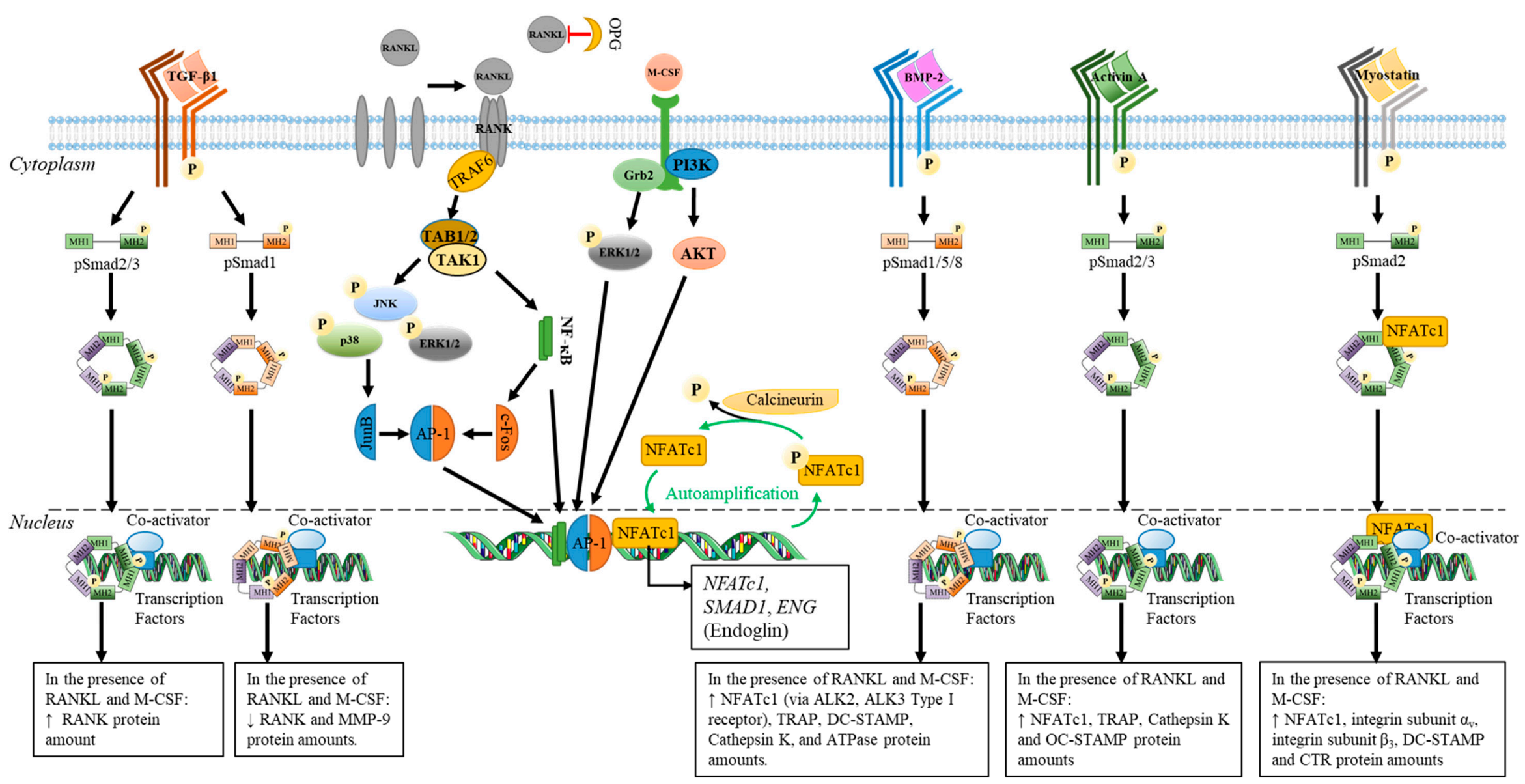

Figure 4. Crosstalk between TGF- $\beta$ superfamily signaling and M-CSF/RANKL pathways to regulate osteoclast differentiation and function [59,184,325]. CTR: Calcitonin receptor; DC-STAMP: Dendritic cell-specific transmembrane protein; MMP: Matrix metalloproteinase; OC-STAMP: Osteoclast Stimulatory Transmembrane Protein; and TRAP: Tartrate-resistant acid phosphatase. The figure was created using Servier Medical Art. https://smart.servier.com. 


\subsection{Temporal Expression of the Members of TGF- $\beta$ Superfamily during the Bone Fracture Healing Process}

The members of the TGF- $\beta$ superfamily were detected in all phases of the bone fracture healing, but their temporal expression patterns and amounts might vary in function of the animal model used [334-336]. Their effects are also coordinated with those of inflammatory cytokines, other growth factors (PDGF, VEGF, FGF1, and FGF2) and extracellular matrix proteins like type I collagen [337-339].

Cho et al. followed the mRNA levels of TGF- $\beta$ s and BMPs in fractured mouse tibias for 4 weeks [334]. They found that TGF- $\beta 1$ is already highly expressed before the fracture occurs. However, its transcript level slightly increases during the hematoma-inflammation formation phase, 1 day after the fracture. It then remains highly expressed within 28 days, but at a level similar to that detected before the fracture. In contrast, TGFB2 and TGFB3 genes are only expressed after the fracture and in a smaller amount than TGF- $\beta 1$ mRNA. Both TGF- $\beta 2$ and TGF- $\beta 3$ transcript levels remain high between days 1-7 and days 1-21, respectively. Thus, while TGF- $\beta 2$ is mainly expressed during the fibrocartilaginous callus formation, TGF- $\beta 3$ appears to act during both fibrocartilaginous and bony callus formation (bone repair phase). Indeed, the gene (COL2A1) encoding type II collagen specific to the cartilaginous matrix is highly expressed at day 7 , while the expression of gene (COL1A1) encoding type I collagen specific to the osteoid matrix reaches a maximum, at days 14 and 21 [334].

It was also confirmed that human fracture hematoma contains a high concentration of TGF- $\beta 1$ [340]. Interestingly, Zimmermann et al. suggested that the amount of TGF- $\beta 1$ in human serum can be used as an indicator of non-union fracture. They found that a drastic decrease in TGF- $\beta 1$ serum level occurs at 4 weeks, in patients suffering from delayed fracture healing, compared to patients with normal healing [341]. However, Sarahrudi et al. did not find any difference in the concentration of TGF- $\beta 1$, in serum from patients with normal and impaired fracture healing, suggesting that further comparative studies must be performed to confirm TGF- $\beta 1$ as a potential marker of non-union fractures [340]. In addition, Burska et al. recently suggested that TGF- $\beta 2$ and placenta growth factor might also be promising markers of human fracture healing [105].

Cho et al. also observed that among BMPs, BMP-2 is the earliest activated gene in fractured mouse tibias. The kinetic profiles of the BMP-2 transcripts reveal two peaks of similar intensity at day 1 (hematoma-inflammation formation phase) and day 21 (bone repair phase). The expression of genes encoding BMP-4, BMP-7, and BMP-8 reaches a peak between 14 and 21 days, corresponding to the bone repair phase [334]. In contrast, Cottrell et al. found that BMP-2 transcript level is almost 4-fold higher at 21 days than that at day 2 in the femur fracture calluses of female Sprague-Dawley rats. They also showed that only the expression of genes encoding for BMP-2 and BMP-4 changes over time. The highest mRNA level of BMP-2, BMP-4 (as well as TNF- $\alpha$ ), at 21 days, is in accordance with an increase in osteoclast resorption activity during callus bone remodeling [336]. The expression of Ser/Thr kinase receptors can also vary during bone fracture healing [342]. Furthermore, bone cells involved in the fracture healing process can differently express the member of the TGF- $\beta$ superfamily. Using human fracture callus specimen (5 patients between 15 and 44 years old), Kloen et al. found that the staining of BMP-2 and BMP-4 is less intense in the osteoblasts than that of BMP-7 [343]. In contrast, mature chondrocytes highly express BMP-2 and BMP-4. Both BMPs are also found in newly synthesized osteoid matrix. In addition, BMP-4 is not detected in osteoclasts, while some of them express BMP-7, BMP-2, and BMP-3. BMPs are also co-localized with their Ser/Thr kinase receptors and pSmad1 [343]. 
Age can affect the fracture healing and BMP gene expression profile obtained during the fracture healing process. Using a closed mid-diaphyseal fracture in 6 weeks and 1-year-old rats, Meyer et al. found that only younger rats present a fracture healing at 6 weeks [335]. The fracture induces the expression of BMP-2 in both younger and older rats. Nevertheless, BMP-2 transcripts level reaches a peak at 1 week in younger rats, while it is observed only after 2 weeks in older ones. In addition, BMP-2 mRNA level in the younger rats is higher than that observed in the older rats. BMP-4 and BMP- 6 mRNA are detected before the fracture in younger rats. Again, both BMP-4 and BMP-6 transcripts reach a peak at 1 and 2 weeks for younger and older rats, respectively. These different mRNA kinetic profiles or transcript amount might explain the delayed fracture healing in older rats [335].

\subsection{TGF- $\beta$ Family Members and Bone Diseases}

Abnormal TGF- $\beta$ signaling and polymorphisms in TGF- $\beta 1$ are involved in widespread human disorders, such as fibrosis and cardiovascular diseases, as well as hereditary or sporadic cancers. Various heritable developmental disorders in humans are caused by mutations in the TGF- $\beta$ system [15,344]. Given the importance of TGF- $\beta$ signaling in bone remodeling, particularly as a coupling factor between resorption and formation, it is not surprising that members of the TGF- $\beta$ family are also implicated in metabolic bone diseases (osteoporosis) or bone malignancies (metastases, multiple myeloma). Similarly, a bone phenotype might be observed upon mutations of one of the genes encoding a member of the TGF- $\beta$ family or of its receptors.

\subsubsection{TGF- $\beta$ Signaling and Osteoporosis}

Osteoporosis is a systemic bone disorder characterized by low bone mass and microarchitectural deterioration, with consequent bone fragility and an increase risk of fractures. Bone loss occurs in postmenopausal women as a result of an increase in the rate of bone remodeling, and an imbalance between bone resorption, which is higher than bone formation [345]. The large increase in bone resorption is related to an increase in osteoclastogenesis. Estrogens increase TGF- $\beta$ secretion by osteoblasts, and this factor could be responsible for the estrogen-induced osteoclast apoptosis [346]. TGF- $\beta$ reduce RANKL expression, and both TGF- $\beta$ and estrogens increase OPG expression $[347,348]$. However, the effects of TGF- $\beta 1$ are complex. If TGF- $\beta 1$ decreases the RANKL:OPG ratio and inhibits the recruitment of osteoclasts, its effect on the mature osteoclast would be rather stimulating [349]. Furthermore, it was recently shown that adding RANKL to M-CSF-stimulated bone marrow mononuclear cells can increase the expression levels of genes encoding BMP-2 and BMP-7 within 1 day. The resulting secreted BMPs activate Smad1/5/9 promoting osteoclast fusion [59].

Genetic polymorphisms of members of the TGF- $\beta$ family are associated with osteoporosis and low bone mass, such as polymorphisms in the genes encoding TGF- $\beta$, BMP2, and BMP4 [350].

\subsubsection{TGF- $\beta$ Signaling and Osteogenesis Imperfecta}

Osteogenesis imperfecta (OI) is an autosomal dominant form of osteoporosis most often caused by mutations in type I collagen genes (COL1A1, COL1A2). The altered quality of the bone matrix, composed mainly of type I collagen, could stimulate TGF- $\beta$ signaling. In fact, the TGF- $\beta$ produced by osteoblasts is secreted and included in the bone matrix in an essentially latent form. During osteoclastic bone resorption, this coupling factor is released and activated. However, the matrix environment of OI results in excessive TGF- $\beta$ activation and signaling, which contributes to low bone mass [351]. TGF- $\beta$ appears as a pathogenic factor and has become a therapeutic target in OI, with favorable effects of its blockade by neutralizing anti-TGF- $\beta$ antibodies in two mouse models of OI, Crtap-/and +/G610C mice, with increased bone mass [351]. However, in another OI model, Col1a1 Jrt/+ mice, which differ from the previous ones by a clear propensity to fractures, the administration of the same anti-TGF- $\beta 1$ D11 antibody had no impact on bone mass, nor on the quality of the bone matrix [352]. 


\subsubsection{TGF- $\beta$ Signaling in Bone Malignancies}

- Bone metastases

In breast carcinoma metastases, osteolytic bone disease is observed in the vicinity of the tumor cells, where a vicious circle is created. Indeed, during osteolysis, growth factors such as TGF- $\beta$ are released and these contribute to the growth of bone metastases, and TGF $\beta$ strongly stimulates the production of PTHrP by tumor cells [353,354].

- Multiple Myeloma

Multiple myeloma (MM) is a B cell malignancy characterized by the presence of an expanded monoclonal population of plasma cells secreting a monoclonal immunoglobulin in the bone marrow, and the development of an osteolytic bone disease [355].

Many osteoclast activation factors were identified in myeloma bone disease [356], among them TGF- $\beta$ is present in the bone matrix and is released upon resorption. TGF- $\beta$ stimulate the production of IL-6 and RANKL and the development of Th17 cells, thereby increasing osteolysis and decreasing bone formation. In preclinical models, blockade of TGF- $\beta$ signaling by a type I receptor inhibitor [357], or by administration of a small peptide with a sequence derived from the latent form of TGF- $\beta$, which blocked TSP1-TGF- $\beta$ binding (and thus TGF- $\beta$ activation), reduced tumor burden, decreased bone resorption, and stimulated bone formation [358].

- $\quad$ Targeting Activin A in Myeloma

Activin A, produced after interaction of bone marrow cells with myeloma cells, stimulates osteoclastic resorption, and inhibits osteoblast formation. High levels of activin A, correlating with the extent of osteolysis and with poor survival, were reported in subjects with advanced MM [359]. In a mouse model of MM, the administration of an activin antagonist-a soluble form of the extracellular domain of the type IIA receptor of activin coupled to the Fc fragment of Ig (RAP-011) - decreased the number of osteolytic lesions, increased bone mass, and decreased tumor burden [360].

ACE-011 is a fusion protein composed of the extracellular domain of the human activin receptor type IIA linked to the Fc fragment of human IgG1, capable of binding activin. Administration of ACE-011 results in an increase in bone formation markers, and a decrease in bone resorption markers (phase I study in postmenopausal women) [361]. In a phase II study in multiple myeloma, the activin A antagonist (sotatercept or ACE-011), in combination with chemotherapy, was found to significantly increase bone mass [362].

- $\quad$ TGF- $\beta$ Family in Monogenic Developmental Bone Diseases

Mutations in genes of BMP receptors are implicated in human skeletal disorders, such as BMPR1B encoding the BMPR-IB receptor in acromesomelic chondrodysplasia [363] and ACVR1 encoding ALK2 in progressive fibrodysplasia ossifying (FOP) [364].

FOP, a rare genetic disorder with an incidence of one in two million, is characterized by progressive ectopic bone formation in soft tissue (heterotopic ossification $(\mathrm{HO})$ ) such as skeletal muscle, tendon, ligament), either spontaneously or after trauma [365] (for review see [366]). ACVR1 mutations do not affect the expression of ALK2 but result in an increase in ALK2 gain of function related to a R206H substitution in the intracellular GS-rich domain of the receptor linked to 95\% of the patients [364,367]. Thus, the BMP signal transduction in FOP cells, through the canonical (Smad) and non-canonical (MAPK) pathways, is overactive, leading to the transcription of targeted genes [368,369]. Using an in vivo model of injury-induced HO (Acvr1R206H/+ knock-in mouse), Haupt et al. found that injured tissue at early stages of repair, is stiffer, favoring permissive condition to $\mathrm{HO}$ formation. The small Rho GTPase mechano-signaling pathway (Rho/ROCK) is also over-activated in the Acvr1 R206H/+ cells and might act synergistically with BMPs, to favor osteogenesis [370]. It was also shown that the R206H 
substitution rendered ACVR1 responsive to activin A, which generally antagonize BMP signaling through ACVR1 but cannot normally induce bone formation. Inhibition of activin A in a knock-in model of ACVR1 R206H, using a blocking antibody, completely inhibits the development of HO [371].

Camurati-Engelmann disease is a progressive diaphyseal dysplasia, presenting with a characteristic thickening of the long bone diaphysis, mainly femurs, with an increase in bone density. Camurati disease is autosomal dominant, and mutations in TGFB1 encoding TGF- $\beta 1$ were reported, mostly located in the latency-associated domain of TGF- $\beta 1$, and suggest an increase in TGF- $\beta$ signaling [372].

Finally, somatic mutations in SMAD3 were described in Melorheostosis, a sporadic bone disease. Melorheostosis is a sclerosing bone dysplasia, characterized by cortical hyperostosis, affecting endosteal and periosteal surfaces, with a typically asymmetric distribution, and a classic "dripping candle wax" radiological appearance. SMAD3 mutations increase TGF- $\beta$ signaling and stimulate osteogenesis [373]. Mutations in MAP2K1 was already reported in this disease by the same authors, with a different clinical and histological profile [374].

\section{The Use of Members of the TGF- $\beta$ Superfamily in Clinical Application and Their Potential Adverse Effect}

The use of BMPs for therapeutic purposes necessarily involves large-scale production to meet market needs. The extraction and purification of small quantities of BMPs began from demineralized cadaveric bovine bone sources, a technique that required a very long production time and a contribution of several kilograms of bone at a very high cost (several $\mathrm{kg}$ of bone $=\mu \mathrm{g}$ of purified BMPs) [375]. Subsequently, this procedure was replaced by the molecular cloning of coding sequences (cDNA) for members of the BMPs family expressed in different recombinant systems (Bacteria: Escherichia coli; Yeast based: Pichia pastoris; Baculovirus/insect cell system (Baculovirus Expression Vector Systems: BEVS); and Mammalian cells: Chinese hamster ovary (CHO)) [137,376-378]. This strategy made it possible to obtain a higher yield of proteins and a better reproducibility, reliability, and safety of the BMPs produced. However, in addition to large-scale production, BMPs must be expressed in a system that ensures biological activity without immunogenicity, so that they can be used for therapeutic purposes. It is necessary to use eukaryotic expression systems that are capable of inducing glycosylation of BMPs [379]. Indeed, this glycosylation is of critical importance, since it deeply affects the biological activity, the elimination, and recognition by the body (antigenicity) of proteins [380]. Thus, genetic engineering that allows the cloning of cDNA in $\mathrm{CHO}$ cells is used for the production of clinical quality BMPs in large quantities [381].

To date, the FDA approved the use of two types of rhBMPs (rhBMP-2 and rhBMP-7) associated with commercial delivery systems as an alternative to autologous bone graft in specific orthopedic applications (InFUSE ${ }^{\circledR}$ and OP-1 ${ }^{\circledR}$ ) [382]. RhBMP-2 was approved for use in human spine surgery on a collagen sponge support absorbable by the $\operatorname{InFUSE}^{\circledR}$ system (Medtronic Sofamor Danek, Inc.) [383-385]. However, rhBMP-7 only received a "Humanitarian Device Exemption" in 2004, for use in compromised patients that require revision of posterolateral (intertransversed) lumbar arthrodesis, for whom bone removal is not possible [386,387]. The rhBMP-7 was used in combination with bovine bone collagen (OP-1 Implant ${ }^{\circledR}$ ) (Stryker Biotech/Olympus) and with carboxymethylcellulose (OP-1 Putty ${ }^{\circledR}$ ) (Stryker Biotech/Olympus). 
Recent studies demonstrated the benefits of using rhBMP-2 and rhBMP-7 for orthopedic treatments and surgeries, particularly in spinal fusion, lumbar fusion, and tibial fracture repair [388-391] (Table 3). While BMP-7 treatment results in decreased operating time for lumbar fusion, rhBMP-2 decreases the risk of re-operation and improves the success of lumbar fusion and bone union of tibial fractures [389-391]. However, many studies also reported complications related to the use of BMP-2, especially for cervical fusions associated with pain, wound infections, dysphagia, and hoarseness, leading to a large increase in hospital costs [392-394]. In 2008, the FDA warned the public health concerning the use of BMP-2 in anterior cervical fusion applications. Furthermore, OP-1 devices that were sold initially by Stryker and then by Olympus in 2010, are not produced anymore, despite the fact that BMP-7 is still used in several clinical trials (Table 3). Indeed, the commercial scaffolds used to deliver rhBMPs to the surgical site are mainly composed of collagens. These proteins can be rapidly degraded in the body by proteolysis during the first days, after the operation, due to the inflammatory response induced by the surgery $[381,382]$. To counterbalance the intense proteolytic activity at the implantation site, the doses of rhBMP used are also often very high (AMPLIFY тM, rhBMP-2, $40 \mathrm{mg}$ ), particularly in commercial applications for spinal fusions, and are associated with a higher risk of cancer and adverse effects [392]. The use of increased doses of BMP-2 for spinal repair surgeries is associated with overactivation of osteoclasts, leading to complications such as osteolysis and graft subsidence [395-397]. The addition of bisphosphonate in combination with BMP-2 treatment, can reduce bone resorption, while promoting new bone formation [398].

Furthermore, higher osteoinductive activity of BMP-6 and BMP-9, compared to BMP-2 or BMP-7, make them promising candidates for promoting bone repair or filling, as shown by several recent studies [399-401]. For example, a recent randomized, double-blinded, placebo-controlled phase I/II clinical trial revealed that autologous blood coagulum combined with rhBMP-6 $(1.0 \mathrm{mg} / 10 \mathrm{~mL})$ promoted bone healing in patients with high tibial osteotomy [401].

Therefore, the heterogeneity of the experimental approach (type of BMP used, doses, and mode of administration) and the diversity of existing bone repair applications made the conclusions of most studies unclear [402]. Future clinical trials should be randomized, double-blind, and properly designed, in order to present a better understanding of the real potential of BMP applications [391,402]. A big challenge in the clinical application of rhBMP is to improve the properties of the delivery systems, in order to have a better control over the spatial and release cytokine kinetics in vivo. 
Table 3. The use of rhBMP-2/rhBMP-7 in bone clinical application and their potential adverse effect [381].

\begin{tabular}{|c|c|c|c|c|c|}
\hline rhBMP & Clinical Application & Methodology & Dose & Conclusion and Adverse Effect & Refs \\
\hline BMP-2 & $\begin{array}{l}\text { Anterolateral interbody } \\
\text { fusion }\end{array}$ & $\begin{array}{l}3105 \text { patients (anterolateral interbody fusion: } \\
\text { 2000-2012) from } 14 \text { trials (PubMed database and } \\
\text { FDA approval document) }\end{array}$ & $2.1-18 \mathrm{mg}$ & $\begin{array}{l}\text { Safe under FDA-approved recommendations (i.e., one-level anterolateral } \\
\text { interbody fusion surgery with an LT-cage); Low complications } \\
\text { (subsidence, cancer, infection); Equal efficiency (fusion rate, pain } \\
\text { disability, patient satisfaction, risk of re-operations) between BMP-2, } \\
\text { allogenic or autologous bone graft; Safety and effectiveness of BMP-2 in } \\
\text { off-label use: not established. }\end{array}$ & {$[388$} \\
\hline BMP-2 & $\begin{array}{l}\text { Spinal fusion } \\
\text { surgery/degenerative disc } \\
\text { disease (control: iliac crest } \\
\text { bone graft (ICBG)) }\end{array}$ & $\begin{array}{l}1408 \text { patients (spinal fusion: } 1997-2012 \text { ) from } 12 \\
\text { trials (mostly sponsored by Medtronic) }\end{array}$ & $\begin{array}{l}\text { Infuse }{ }^{\circledR}(1.5 \mathrm{mg} / \mathrm{mL}) \\
\text { Amplify }^{\circledR}(2.0 \mathrm{mg} / \mathrm{mL})\end{array}$ & $\begin{array}{l}\uparrow \text { early postsurgical pain compared with ICBG; Evidence of } \uparrow \text { cancer } \\
\text { incidence is inconclusive; } \uparrow \text { fusion rates at } 24 \text { months. }\end{array}$ & {$[403$} \\
\hline BMP-2 & $\begin{array}{l}\text { Spinal fusion (control: } \\
\text { bone graft) }\end{array}$ & $\begin{array}{l}1984 \text { patients (spinal fusion: 1996-2012) from } 13 \\
\text { trials (sponsored by Medtronic and } \\
\text { Norton Healthcare) }\end{array}$ & $\begin{array}{l}0.6 \text { to } 16.8 \mathrm{mg}(11 \text { trials }) \\
15.0 \text { to } 63.0 \mathrm{mg}(5 \text { trials of } \\
\text { posterolateral lumbar } \\
\text { fusion studies })\end{array}$ & $\begin{array}{l}\uparrow \text { complication in anterior cervical fusion: wound complication and } \\
\text { dysphagia.; No proven clinical advantage over bone graft in spinal. } \\
\text { fusion: May be associated with important harms (retrograde ejaculation } \\
\text { and urogenital problems); } \uparrow \text { cancer risk at } 24 \text { months. }\end{array}$ & [394] \\
\hline BMP-2 & Spinal fusion & $\begin{array}{l}\text { 55,862 patients (spinal fusion: 2004-2007) from } \\
\text { the Scoliosis Research Society database (BMP } \\
\text { used in } 21 \% \text { of all spinal fusions) }\end{array}$ & N.A. & $\begin{array}{c}\text { } \uparrow \text { incidence of complications and wound infections in anterior cervical } \\
\text { fusions; Not associated with } \uparrow \text { complications in thoracolumbar and } \\
\text { posterior cervical fusions. }\end{array}$ & {$[393$} \\
\hline BMP-2 & Spinal fusion & $\begin{array}{l}780 \text { patients (1995-2010) from } 13 \text { trials } \\
\text { (sponsored by industry). }\end{array}$ & $0.6-40 \mathrm{mg}$ & $\begin{array}{l}\uparrow \uparrow \text { complications and adverse events in spinal fusion; Possible study } \\
\text { design bias in the original trials: risk of adverse events around } 10 \text { to } 50 \\
\text { fold that of the original estimates reported in publications sponsored by } \\
\text { industry; Higher doses of BMP-2: associated } \uparrow \text { risk of new malignancy. }\end{array}$ & {$[395$} \\
\hline BMP-2 & $\begin{array}{l}\text { Lumbar and lumbosacral } \\
\text { fusion }\end{array}$ & $\begin{array}{l}129 \text { patients (2000-2008) from the New York } \\
\text { Harbor Health Care System Manhattan Veterans } \\
\text { Administration operating room record }\end{array}$ & 12 and $24 \mathrm{mg}$ & $\begin{array}{l}\text { Higher doses of rhBMP2 in lumbar and lumbosacral fusion: may } \uparrow \text { risk } \\
\text { of renal insufficiency. }\end{array}$ & {$[404$} \\
\hline BMP-7 & $\begin{array}{l}\text { Single-level lumbar fusion } \\
\text { (control: ICBG) }\end{array}$ & $\begin{array}{l}539 \text { patients (2002-2016) from } 5 \text { trials (PubMed, } \\
\text { EMBASE, Scopus, and the Cochrane } \\
\text { Collaboration Library databases) }\end{array}$ & $\begin{array}{l}\text { 3.5 mg of (rh)BMP-7 } \\
\text { (Osigraft or Putty) } \\
\text { per side }\end{array}$ & $\begin{array}{l}\text { Shorter operation times; No additional beneficial effect (clinical success, } \\
\text { revision rates and duration of hospitalization) between BMP-7 and ICBG; } \\
\downarrow \text { lumbar fusion rate (in instrumented posterolateral fusion). }\end{array}$ & {$[389$} \\
\hline BMP-2 and/or BMP-7 & Lumbar fusion & 2185 patients (2000-2016) from 21 trials & $12-48 \mathrm{mg}$ & $\begin{array}{c}\uparrow \text { lumbar fusion success rate (BMP-2) and } \downarrow \text { risk of re-operation; No } \\
\text { difference in complication rate between BMPs and ICBG. }\end{array}$ & {$[390$} \\
\hline BMP-2 and/or BMP-7 & $\begin{array}{l}\text { Treatment of fractures, } \\
\text { non-union and } \\
\text { osteonecrosis }\end{array}$ & $\begin{array}{l}3324 \text { patients (1601 fracture, } 1654 \text { non-unions } \\
\text { and } 69 \text { osteonecrosis: from } 2000 \text { to 2016) from } 43 \\
\text { trials (PubMed database) }\end{array}$ & $\begin{array}{c}\text { Inductos }{ }^{\circledR}(0.75,1.5 \text { or } 2.0 \\
\mathrm{mg} / \mathrm{mL}) ; \text { Infuse }{ }^{\circledR}(1.5 \\
\mathrm{mg} / \mathrm{mL}) ; \text { OP- } 1 \text { Stryker }(3.3 \\
\text { and } 3.5 \mathrm{mg} / \mathrm{mL}) ; \text { Osigraft } \\
(3.5 \mathrm{mg} / \mathrm{mL})\end{array}$ & $\begin{array}{l}\text { Controversial clinical evidence (fractures, non-union, and osteonecrosis); } \\
\text { Preliminary knowledge and few low quality reports; Positive findings in } \\
\text { many studies, but mixed efficacy and adverse events in overall literature; } \\
\text { Unclear conclusions (heterogeneity of studies: different BMPs, doses and } \\
\text { delivery method for each bone pathology). }\end{array}$ & {$[402$} \\
\hline BMP-2 and/or BMP-7 & $\begin{array}{l}\text { Tibial fracture and } \\
\text { nonunion }\end{array}$ & $\begin{array}{l}1113 \text { patients (tibial fracture and nonunion: } 1997 \\
\text { to 2011) from } 8 \text { trials (MEDLINE, EMABSE, } \\
\text { BIOSIS and Cochrane central data bases) }\end{array}$ & $3.5,6$ or $12 \mathrm{mg}$ & $\begin{array}{l}\uparrow \text { effectiveness of bone union and } \downarrow \text { risk of re-operation (tibial fractures); } \\
\text { Equal efficiency (bone union, infection, or re-operations rate) between } \\
\text { BMPs and autologous bone graft to treat tibial fractures non-union. }\end{array}$ & {$[391]$} \\
\hline BMP-2 and BMP-7 & Spinal fusion & $\begin{array}{l}941 \text { patients from } 7 \text { trials from Pubmed, } \\
\text { Cochrane, National Guideline Clearinghouse } \\
\text { databases, FDA safety summaries (2012) }\end{array}$ & $4-40 \mathrm{mg}$ & $\uparrow$ cancer risk dependent on the dose of BMP used. & {$[405$} \\
\hline
\end{tabular}

$\downarrow$ : Decrease; $\uparrow:$ Increase; $\uparrow \uparrow$ Strongly increase; N.A.: not available. 


\section{Conclusions}

The members of the TGF- $\beta$ superfamily are potent regulators of homeostasis and bone repair that act on cell proliferation, osteogenic differentiation, osteoclastogenesis, and osteoblast/osteoclast balance. A good understanding of their characteristics, biological functions, canonical, and non-canonical signaling pathways, as well as their respective regulation is essential for allowing their safe use in the restoration of injured or diseased skeletal tissues. Despite their incredible potential for improving bone repair, they are linked to various postoperative complications (wound infections, dysphagia, tissue damage, cancer risks, etc.) pushing the FDA to limit their use to specific orthopedic application. The reduction of the applied BMP doses, as well as the development of delivery systems allowing a good control of their spatial and temporal release, seem to be the keys to their safe and effective clinical use. However, future well-designed studies are needed to get a better picture of the advantages and drawbacks associated with the use of the TGF- $\beta$ superfamily members in clinical applications.

Author Contributions: J.J. and S.G. wrote the draft of the manuscript and designed the tables under the supervision of S.R. and N.F. S.R. and N.F. contributed to the writing and editing of the manuscript, tables, and figures. All authors have read and agreed to the published version of the manuscript.

Funding: The APC was funded by Natural Sciences and Engineering Research Council of Canada program (grant number 33062).

Acknowledgments: The authors would like to thank O. Drevelle for his contribution in editing the figures.

Conflicts of Interest: The authors declare no conflict of interest.

$\begin{array}{ll}\text { Abbreviations } & \\ \text { 1,25-(OH)2D3 } & \text { 1 } 2 \text { 25-dihydroxyvitamin } \mathrm{D}_{3} \\ \text { ActRIIA } & \text { Type II activin receptor } \\ \text { ActRIIB } & \text { Type IIB activin receptor } \\ \text { ALK } & \text { Activin receptor-like kinases receptor } \\ \text { ALP } & \text { Alkaline phosphatase } \\ \text { AMH/MIS } & \text { Anti-Müllerian hormone/Müllerian inhibiting substance } \\ \text { AMHRII } & \text { Anti-Mullerian hormone receptor type II } \\ \text { AP-1 } & \text { Activator protein 1 } \\ \text { APC } & \text { Adenomatous polyposis coli } \\ \text { BAMBI } & \text { Bone morphogenetic protein and activin membrane-bound inhibitor } \\ \text { BMMs } & \text { Bone marrow-derived macrophage } \\ \text { BMP } & \text { Bone morphogenetic proteins } \\ \text { BMPRII } & \text { Type II BMP receptor } \\ \text { BMU } & \text { Basic multicellular unit } \\ \text { BSP } & \text { Bone sialoprotein } \\ \text { CA2 } & \text { Carbonic anhydrase enzymes } \\ \text { CAMKII } & \text { Calmodulin-dependent kinase II } \\ \text { CDK8 } & \text { Cyclin-dependent kinase 8 } \\ \text { CEBP } \alpha & \text { CCAAT-enhancer binding protein } \alpha \\ \text { CHO } & \text { Chinese hamster ovary } \\ \text { CKI } & \text { Casein kinase I } \\ \text { CRD } & \text { Extracellular N-terminal cysteine-rich domain } \\ \text { CREB } & \text { Cyclic AMP response element-binding protein } \\ \text { CSF-1 } & \text { Colony stimulating factor 1 } \\ \text { CTR } & \text { Calcitonin receptor } \\ \text { DAG } & \text { Diacylglycerol } \\ \text { DAP12 } & \text { DNAX associated protein 12kD size } \\ \text { Dkk } & \text { Dickkopf } \\ \text { DLL } & \\ \text { dpp } & \\ & \text { Delta-like } \\ & \end{array}$




\begin{tabular}{|c|c|}
\hline DVL & Disheveled \\
\hline ENG & Endoglin \\
\hline ERK & Extracellular signal-regulated kinase \\
\hline FGF & Fibroblast growth factor \\
\hline FKBP12 & FK506 binding protein of $12 \mathrm{kDa}$ \\
\hline FOP & Fibrodysplasia ossifying \\
\hline FSH & Follicle-stimulating hormone \\
\hline $\mathrm{Fz}$ & Frizzled \\
\hline GDF & Growth differentiation factors \\
\hline Grb2 & Growth factor receptor bound protein 2 \\
\hline GSK3 $\beta$ & Glycogen synthase kinase- $3 \beta$ \\
\hline GS motif & Gly/Ser rich motif \\
\hline HAT & Histone acetyltransferases \\
\hline HES & Hairy enhancer of split \\
\hline HEY & HES-related with YRPW motif \\
\hline $\mathrm{HO}$ & Heterotopic ossification \\
\hline ID1 & DNA binding protein 1 \\
\hline IGF & Insulin like growth factor \\
\hline IL & Interleukins \\
\hline IP3 & Inositol-1,4,5-trisphosphate \\
\hline I-Smad & Inhibitory Smad \\
\hline JAG & Jagged \\
\hline JNK & c-Jun amino $(\mathrm{N})$-terminal kinases \\
\hline LAP & Latency associated peptide \\
\hline LEF & Lymphoid enhancer-binding factor \\
\hline LGR4 & Leucine rich repeat containing G-coupled receptor 4 \\
\hline LRP5/6 & Low-density-lipoprotein-related protein 5/6 \\
\hline LTBP & Latent TGF- $\beta$ binding protein \\
\hline MAML & Adaptor protein Mastermind-like \\
\hline MAPK & Mitogen-activated protein kinase \\
\hline M-CSF & Macrophage- colony stimulating factor \\
\hline MH1 & Mad homology 1 domain \\
\hline miRNAs & microRNAs \\
\hline MITF & Micropthalmia-associated transcription factor \\
\hline MMP-9 & Matrix metalloproteases \\
\hline MSCs & Mesenchymal stem cells \\
\hline NFATc1 & Nuclear factor of activated T cells \\
\hline NF- $k B$ & Nuclear factor of $\kappa B$ \\
\hline NICD & Notch intracellular domain \\
\hline ODF & Osteoclast differentiation factor \\
\hline OPG & Osteoprotegerin \\
\hline OPGL & Osteoprotegerin ligand \\
\hline OSCAR & Osteoclast-associated receptor \\
\hline PI3K & Phosphoinositide 3-kinase \\
\hline PKC & Protein kinase $\mathrm{C}$ \\
\hline PLC & Phospholipase C \\
\hline PPAR $\gamma$ & Peroxisome proliferation-activated receptor $\gamma$ \\
\hline PPM1A & Protein phosphatase magnesium-dependent $1 \mathrm{~A}$ \\
\hline $\begin{array}{l}\text { RANKL } \\
\operatorname{rhBMP} 2 / 7\end{array}$ & $\begin{array}{l}\text { Receptor activator of nuclear factor kappa beta ligand } \\
\text { rhBMP-2/BMP-7 heterodimer }\end{array}$ \\
\hline R-Smad & Receptor-regulated Smad proteins \\
\hline Runx2 & Runt-related transcription factor 2 \\
\hline SARA & Smad anchor for receptor activation protein \\
\hline
\end{tabular}




$\begin{array}{ll}\text { sFRPs } & \text { Fz-related proteins } \\ \text { SGFs } & \text { Sarcoma growth factors } \\ \text { SIBLING } & \text { Small integrin-binding ligand N-linked glycoprotein } \\ \text { Smad } & \text { Small mothers against decapentaplegic } \\ \text { Smurf } & \text { Smad ubiquitin regulatory factor } \\ \text { TAB1 } & \text { TAK1-binding protein } 1 \\ \text { TACE } & \text { Tumor Necrosis Factor } \alpha \text {-converting enzyme } \\ \text { TAK1 } & \text { Transforming growth factor } \beta \text {-activated kinase 1 } \\ \text { T } \beta \text { RII } & \text { TGF- } \beta \text { RII } \\ \text { TCF } & \text { T cell factor } \\ \text { TNF } & \text { Tumor necrosis factor } \\ \text { TGF- } \beta & \text { Transforming growth factor } \beta \\ \text { TRAFs } & \text { Tumor necrosis factor receptor-associated factors } \\ \text { TRANCE } & \text { Tumor necrosis factor-related activation-induced cytokine } \\ \text { TRAP } & \text { Tartrate-resistant acid phosphatase } \\ \text { TREM2 } & \text { Triggering receptor expressed on myeloid cells-2 } \\ \text { TSP1 } & \text { Thrombospondin } 1 \\ \text { v-ATPase } & \text { Vacuolar protons -transporting adenosine triphosphatase pump } \\ \text { VEGF } & \text { Vascular endothelial growth factor }\end{array}$

\section{References}

1. Florencio-Silva, R.; Sasso, G.R.; Sasso-Cerri, E.; Simoes, M.J.; Cerri, P.S. Biology of Bone Tissue: Structure, Function, and Factors That Influence Bone Cells. BioMed Res. Int. 2015, 2015, 421746. [CrossRef]

2. Marieb, E.N.; Hoen, K. Human Anatomy and Physiology, 5th ed.; Pearson Education Limited: London, UK, 2015.

3. Datta, H.K.; Ng, W.F.; Walker, J.A.; Tuck, S.P.; Varanasi, S.S. The cell biology of bone metabolism. J. Clin. Pathol. 2008, 61, 577-587. [CrossRef]

4. Sharma, S.; Mahajan, A.; Mittal, A.; Gohil, R.; Sachdeva, S.; Khan, S.; Dhillon, M. Epigenetic and transcriptional regulation of osteoclastogenesis in the pathogenesis of skeletal diseases: A systematic review. Bone 2020, 138, 115507. [CrossRef]

5. Alejandro, P.; Constantinescu, F. A Review of Osteoporosis in the Older Adult: An Update. Rheum. Dis. Clin. N. Am. 2018, 44, 437-451. [CrossRef]

6. Calori, G.M.; Tagliabue, L.; Mazza, E.; de Bellis, U.; Pierannunzii, L.; Marelli, B.M.; Colombo, M.; Albisetti, W. Tibial pilon fractures: Which method of treatment? Injury 2010, 41, 1183-1190. [CrossRef]

7. Ho-Shui-Ling, A.; Bolander, J.; Rustom, L.E.; Johnson, A.W.; Luyten, F.P.; Picart, C. Bone regeneration strategies: Engineered scaffolds, bioactive molecules and stem cells current stage and future perspectives. Biomaterials 2018, 180, 143-162. [CrossRef]

8. Maruyama, M.; Rhee, C.; Utsunomiya, T.; Zhang, N.; Ueno, M.; Yao, Z.; Goodman, S.B. Modulation of the Inflammatory Response and Bone Healing. Front. Endocrinol. 2020, 11, 386. [CrossRef]

9. Walters, G.; Pountos, I.; Giannoudis, P.V. The cytokines and micro-environment of fracture haematoma: Current evidence. J. Tissue Eng. Regen. Med. 2018, 12, e1662-e1677. [CrossRef]

10. Fischer, V.; Haffner-Luntzer, M.; Amling, M.; Ignatius, A. Calcium and vitamin D in bone fracture healing and post-traumatic bone turnover. Eur. Cells Mater. 2018, 35, 365-385. [CrossRef]

11. Anderson, P.H. Vitamin D Activity and Metabolism in Bone. Curr. Osteoporos. Rep. 2017, 15, 443-449. [CrossRef]

12. Linkhart, T.A.; Mohan, S.; Baylink, D.J. Growth factors for bone growth and repair: IGF, TGF $\beta$ and BMP. Bone 1996, 19, S1-S12. [CrossRef]

13. Huntley, R.; Jensen, E.; Gopalakrishnan, R.; Mansky, K.C. Bone morphogenetic proteins: Their role in regulating osteoclast differentiation. Bone Rep. 2019, 10, 100207. [CrossRef]

14. Feng, W.; Guo, J.; Li, M. RANKL-independent modulation of osteoclastogenesis. J. Oral. Biosci. 2019, 61, 16-21. [CrossRef]

15. Massagué, J.; Blain, S.W.; Lo, R.S. TGF $\beta$ Signaling in Growth Control, Cancer, and Heritable Disorders. Cell 2000, 103, 295-309. [CrossRef]

16. Massagué, J.; Chen, Y.G. Controlling TGF- $\beta$ signaling. Genes Dev. 2000, 14, 627-644. [CrossRef] 
17. Han, L.; Wang, B.; Wang, R.; Gong, S.; Chen, G.; Xu, W. The shift in the balance between osteoblastogenesis and adipogenesis of mesenchymal stem cells mediated by glucocorticoid receptor. Stem Cell Res. Ther. 2019, 10, 377. [CrossRef]

18. Yuan, Z.; Li, Q.; Luo, S.; Liu, Z.; Luo, D.; Zhang, B.; Zhang, D.; Rao, P.; Xiao, J. PPARgamma and Wnt Signaling in Adipogenic and Osteogenic Differentiation of Mesenchymal Stem Cells. Curr. Stem Cell Res. Ther. 2016, 11, 216-225. [CrossRef]

19. Pittenger, M.F.; Mackay, A.M.; Beck, S.C.; Jaiswal, R.K.; Douglas, R.; Mosca, J.D.; Moorman, M.A.; Simonetti, D.W.; Craig, S.; Marshak, D.R. Multilineage potential of adult human mesenchymal stem cells. Science 1999, 284, 143-147. [CrossRef]

20. Fan, W.; Qian, F.; Ma, Q.; Zhang, P.; Chen, T.; Chen, C.; Zhang, Y.; Deng, P.; Zhou, Z.; Yu, Z. 50 Hz electromagnetic field exposure promotes proliferation and cytokine production of bone marrow mesenchymal stem cells. Int. J. Clin. Exp. Med. 2015, 8, 7394-7404.

21. Moore, E.R.; Chen, J.C.; Jacobs, C.R. Prx1-Expressing Progenitor Primary Cilia Mediate Bone Formation in response to Mechanical Loading in Mice. Stem Cells Int. 2019, 2019, 3094154. [CrossRef]

22. Root, S.H.; Wee, N.K.Y.; Novak, S.; Rosen, C.J.; Baron, R.; Matthews, B.G.; Kalajzic, I. Perivascular osteoprogenitors are associated with transcortical channels of long bones. Stem Cells 2020, 38, 769-781. [CrossRef]

23. Ducy, P.; Zhang, R.; Geoffroy, V.; Ridall, A.L.; Karsenty, G. Osf2/Cbfa1: A Transcriptional Activator of Osteoblast Differentiation. Cell 1997, 89, 747-754. [CrossRef]

24. Komori, T.; Yagi, H.; Nomura, S.; Yamaguchi, A.; Sasaki, K.; Deguchi, K.; Shimizu, Y.; Bronson, R.T.; Gao, Y.H.; Inada, M.; et al. Targeted Disruption of Cbfa1 Results in a Complete Lack of Bone Formation owing to Maturational Arrest of Osteoblasts. Cell 1997, 89, 755-764. [CrossRef]

25. Komori, T. Signaling networks in RUNX2-dependent bone development. J. Cell. Biochem. 2011, 112, 750-755. [CrossRef]

26. Kawane, T.; Qin, X.; Jiang, Q.; Miyazaki, T.; Komori, H.; Yoshida, C.A.; Matsuura-Kawata, V.; Sakane, C.; Matsuo, Y.; Nagai, K.; et al. Runx2 is required for the proliferation of osteoblast progenitors and induces proliferation by regulating Fgfr2 and Fgfr3. Sci. Rep. 2018, 8, 13551. [CrossRef]

27. Nakashima, K.; Zhou, X.; Kunkel, G.; Zhang, Z.; Deng, J.M.; Behringer, R.R.; de Crombrugghe, B. The Novel Zinc Finger-Containing Transcription Factor Osterix Is Required for Osteoblast Differentiation and Bone Formation. Cell 2002, 108, 17-29. [CrossRef]

28. Greenblatt, M.B.; Shim, J.H.; Zou, W.; Sitara, D.; Schweitzer, M.; Hu, D.; Lotinun, S.; Sano, Y.; Baron, R.; Park, J.M.; et al. The p38 MAPK pathway is essential for skeletogenesis and bone homeostasis in mice. J. Clin. Investig. 2010, 120, 2457-2473. [CrossRef]

29. Xu, Y.; Yao, B.; Shi, K.; Lu, J.; Jin, Y.; Qi, B.; Li, H.; Pan, S.; Chen, L.; Ma, C. Phosphorylation of Serine422 increases the stability and transactivation activities of human Osterix. FEBS Lett. 2015, 589, 857-864. [CrossRef]

30. Yu, W.H.; Li, F.G.; Chen, X.Y.; Li, J.T.; Wu, Y.H.; Huang, L.H.; Wang, Z.; Li, P.; Wang, T.; Lahn, B.T.; et al. PPARgamma suppression inhibits adipogenesis but does not promote osteogenesis of human mesenchymal stem cells. Int. J. Biochem. Cell Biol. 2012, 44, 377-384. [CrossRef]

31. Lin, L.; Dai, S.D.; Fan, G.Y. Glucocorticoid-induced differentiation of primary cultured bone marrow mesenchymal cells into adipocytes is antagonized by exogenous Runx2. Apmis 2010, 118, 595-605. [CrossRef]

32. Stechschulte, L.A.; Lecka-Czernik, B. Reciprocal regulation of PPARgamma and RUNX2 activities in marrow mesenchymal stem cells: Fine balance between p38 MAPK and Protein Phosphatase 5. Curr. Mol. Biol. Rep. 2017, 3, 107-113. [CrossRef]

33. Bonewald, L.F. Osteocytes as dynamic multifunctional cells. Ann. N. Y. Acad. Sci. 2007, 1116, $281-290$. [CrossRef]

34. Hynes, R.O. Integrins. Cell 2002, 110, 673-687. [CrossRef]

35. Jikko, A.; Harris, S.E.; Chen, D.; Mendrick, D.L.; Damsky, C.H. Collagen integrin receptors regulate early osteoblast differentiation induced by BMP-2. J. Bone Miner. Res. 1999, 14, 1075-1083. [CrossRef]

36. Nagae, M.; Re, S.; Mihara, E.; Nogi, T.; Sugita, Y.; Takagi, J. Crystal structure of alpha5beta1 integrin ectodomain: Atomic details of the fibronectin receptor. J. Cell Biol. 2012, 197, 131-140. [CrossRef]

37. Sharma, V.; Srinivasan, A.; Nikolajeff, F.; Kumar, S. Biomineralization process in hard tissues: The interaction complexity within protein and inorganic counterparts. Acta Biomater. 2020. [CrossRef] 
38. Tresguerres, F.G.F.; Torres, J.; Lopez-Quiles, J.; Hernandez, G.; Vega, J.A.; Tresguerres, I.F. The osteocyte: A multifunctional cell within the bone. Ann. Anat. 2020, 227, 151422. [CrossRef]

39. Knothe Tate, M.L.; Adamson, J.R.; Tami, A.E.; Bauer, T.W. The osteocyte. Int. J. Biochem. Cell Biol. 2004, 36, 1-8. [CrossRef]

40. Dallas, S.L.; Prideaux, M.; Bonewald, L.F. The osteocyte: An endocrine cell ... and more. Endocr. Rev. 2013, 34, 658-690. [CrossRef]

41. Pereira, M.; Petretto, E.; Gordon, S.; Bassett, J.H.D.; Williams, G.R.; Behmoaras, J. Common signalling pathways in macrophage and osteoclast multinucleation. J. Cell Sci. 2018, 131. [CrossRef]

42. Boyle, W.J.; Simonet, W.S.; Lacey, D.L. Osteoclast differentiation and activation. Nature 2003, 423, 337-342. [CrossRef]

43. Yoshida, H.; Hayashi, S.; Kunisada, T.; Ogawa, M.; Nishikawa, S.; Okamura, H.; Sudo, T.; Shultz, L.D.; Nishikawa, $\mathrm{S}$. The murine mutation osteopetrosis is in the coding region of the macrophage colony stimulating factor gene. Nature 1990, 345, 442-444. [CrossRef]

44. Soe, K.; Delaisse, J.M.; Borggaard, X.G. Osteoclast formation at the bone marrow/bone surface interface: Importance of structural elements, matrix, and intercellular communication. Semin. Cell Dev. Biol. 2020. [CrossRef]

45. Ohtsuki, T.; Hatake, K.; Suzu, S.; Saito, K.; Motoyoshi, K.; Miura, Y. Immunohistochemical identification of proteoglycan form of macrophage colony-stimulating factor on bone surface. Calcif. Tissue Int. 1995, 57, 213-217. [CrossRef]

46. Collin-Osdoby, P.; Rothe, L.; Anderson, F.; Nelson, M.; Maloney, W.; Osdoby, P. Receptor activator of NF-kappa $\mathrm{B}$ and osteoprotegerin expression by human microvascular endothelial cells, regulation by inflammatory cytokines, and role in human osteoclastogenesis. J. Biol. Chem. 2001, 276, 20659-20672. [CrossRef]

47. Tikhonova, A.N.; Dolgalev, I.; Hu, H.; Sivaraj, K.K.; Hoxha, E.; Cuesta-Dominguez, A.; Pinho, S.; Akhmetzyanova, I.; Gao, J.; Witkowski, M.; et al. The bone marrow microenvironment at single-cell resolution. Nature 2019, 569, 222-228. [CrossRef]

48. Ross, F.P. M-CSF, c-Fms, and signaling in osteoclasts and their precursors. Ann. N. Y. Acad. Sci. 2006, 1068, 110-116. [CrossRef]

49. Matic, I.; Matthews, B.G.; Wang, X.; Dyment, N.A.; Worthley, D.L.; Rowe, D.W.; Grcevic, D.; Kalajzic, I. Quiescent Bone Lining Cells are a Major Source of Osteoblasts During Adulthood. Stem Cells 2016, 34, 2930-2942. [CrossRef]

50. Carda, C.; Silvestrini, G.; Gomez de Ferraris, M.E.; Peydro, A.; Bonucci, E. Osteoprotegerin (OPG) and RANKL expression and distribution in developing human craniomandibular joint. Tissue Cell 2005, 37, 247-255. [CrossRef]

51. Nakashima, T.; Hayashi, M.; Fukunaga, T.; Kurata, K.; Oh-Hora, M.; Feng, J.Q.; Bonewald, L.F.; Kodama, T.; Wutz, A.; Wagner, E.F.; et al. Evidence for osteocyte regulation of bone homeostasis through RANKL expression. Nat. Med. 2011, 17, 1231-1234. [CrossRef]

52. Xiong, J.; Onal, M.; Jilka, R.L.; Weinstein, R.S.; Manolagas, S.C.; O’Brien, C.A. Matrix-embedded cells control osteoclast formation. Nat. Med. 2011, 17, 1235-1241. [CrossRef]

53. Xiong, J.; Piemontese, M.; Onal, M.; Campbell, J.; Goellner, J.J.; Dusevich, V.; Bonewald, L.; Manolagas, S.C.; O'Brien, C.A. Osteocytes, not Osteoblasts or Lining Cells, are the Main Source of the RANKL Required for Osteoclast Formation in Remodeling Bone. PLoS ONE 2015, 10, e0138189. [CrossRef]

54. Lacey, D.L.; Timms, E.; Tan, H.L.; Kelley, M.J.; Dunstan, C.R.; Burgess, T.; Elliott, R.; Colombero, A.; Elliott, G.; Scully, S.; et al. Osteoprotegerin Ligand Is a Cytokine that Regulates Osteoclast Differentiation and Activation. Cell 1998, 93, 165-176. [CrossRef]

55. Fennen, M.; Pap, T.; Dankbar, B. Smad-dependent mechanisms of inflammatory bone destruction. Arthritis Res. Ther. 2016, 18, 279. [CrossRef]

56. Amarasekara, D.S.; Yun, H.; Kim, S.; Lee, N.; Kim, H.; Rho, J. Regulation of Osteoclast Differentiation by Cytokine Networks. Immune Netw. 2018, 18, e8. [CrossRef]

57. Park, J.H.; Lee, N.K.; Lee, S.Y. Current Understanding of RANK Signaling in Osteoclast Differentiation and Maturation. Mol. Cells 2017, 40, 706-713. [CrossRef]

58. Ono, T.; Nakashima, T. Recent advances in osteoclast biology. Histochem. Cell Biol. 2018, 149, 325-341. [CrossRef] 
59. Omi, M.; Kaartinen, V.; Mishina, Y. Activin A receptor type 1-mediated BMP signaling regulates RANKL-induced osteoclastogenesis via canonical SMAD-signaling pathway. J. Biol. Chem. 2019, 294, 17818-17836. [CrossRef]

60. Hsu, H.; Lacey, D.L.; Dunstan, C.R.; Solovyev, I.; Colombero, A.; Timms, E.; Tan, H.L.; Elliott, G.; Kelley, M.J.; Sarosi, I.; et al. Tumor necrosis factor receptor family member RANK mediates osteoclast differentiation and activation induced by osteoprotegerin ligand. Proc. Natl. Acad. Sci. USA 1999, 96, 3540-3545. [CrossRef]

61. Luo, J.; Yang, Z.; Ma, Y.; Yue, Z.; Lin, H.; Qu, G.; Huang, J.; Dai, W.; Li, C.; Zheng, C.; et al. LGR4 is a receptor for RANKL and negatively regulates osteoclast differentiation and bone resorption. Nat. Med. 2016, 22, 539-546. [CrossRef]

62. McManus, S.; Chamoux, E.; Bisson, M.; Roux, S. Modulation of tumor necrosis factor related apoptosis-inducing ligand (TRAIL) receptors in a human osteoclast model in vitro. Apoptosis 2012, 17, 121-131. [CrossRef]

63. Lee, S.H.; Rho, J.; Jeong, D.; Sul, J.Y.; Kim, T.; Kim, N.; Kang, J.S.; Miyamoto, T.; Suda, T.; Lee, S.K.; et al. $\mathrm{v}$-ATPase V0 subunit d2-deficient mice exhibit impaired osteoclast fusion and increased bone formation. Nat. Med. 2006, 12, 1403-1409. [CrossRef]

64. Koga, T.; Inui, M.; Inoue, K.; Kim, S.; Suematsu, A.; Kobayashi, E.; Iwata, T.; Ohnishi, H.; Matozaki, T.; Kodama, T.; et al. Costimulatory signals mediated by the ITAM motif cooperate with RANKL for bone homeostasis. Nature 2004, 428, 758-763. [CrossRef]

65. Humphrey, M.B.; Nakamura, M.C. A Comprehensive Review of Immunoreceptor Regulation of Osteoclasts. Clin. Rev. Allergy Immunol. 2016, 51, 48-58. [CrossRef]

66. McHugh, K.P.; Hodivala-Dilke, K.; Zheng, M.H.; Namba, N.; Lam, J.; Novack, D.; Feng, X.; Ross, F.P.; Hynes, R.O.; Teitelbaum, S.L. Mice lacking beta3 integrins are osteosclerotic because of dysfunctional osteoclasts. J. Clin. Investig. 2000, 105, 433-440. [CrossRef]

67. Li, J.; Sarosi, I.; Yan, X.Q.; Morony, S.; Capparelli, C.; Tan, H.L.; McCabe, S.; Elliott, R.; Scully, S.; Van, G.; et al. RANK is the intrinsic hematopoietic cell surface receptor that controls osteoclastogenesis and regulation of bone mass and calcium metabolism. Proc. Natl. Acad. Sci. USA 2000, 97, 1566-1571. [CrossRef]

68. Azuma, Y.; Kaji, K.; Katogi, R.; Takeshita, S.; Kudo, A. Tumor necrosis factor-alpha induces differentiation of and bone resorption by osteoclasts. J. Biol. Chem. 2000, 275, 4858-4864. [CrossRef]

69. Kudo, O.; Sabokbar, A.; Pocock, A.; Itonaga, I.; Fujikawa, Y.; Athanasou, N.A. Interleukin-6 and interleukin-11 support human osteoclast formation by a RANKL-independent mechanism. Bone 2003, 32, 1-7. [CrossRef]

70. Kitaura, H.; Zhou, P.; Kim, H.J.; Novack, D.V.; Ross, F.P.; Teitelbaum, S.L. M-CSF mediates TNF-induced inflammatory osteolysis. J. Clin. Investig. 2005, 115, 3418-3427. [CrossRef]

71. Braun, T.; Zwerina, J. Positive regulators of osteoclastogenesis and bone resorption in rheumatoid arthritis. Arthritis Res. Ther. 2011, 13, 235. [CrossRef]

72. Yang, Y.; Chung, M.R.; Zhou, S.; Gong, X.; Xu, H.; Hong, Y.; Jin, A.; Huang, X.; Zou, W.; Dai, Q.; et al. STAT3 controls osteoclast differentiation and bone homeostasis by regulating NFATc1 transcription. J. Biol. Chem. 2019, 294, 15395-15407. [CrossRef]

73. Yoshitake, F.; Itoh, S.; Narita, H.; Ishihara, K.; Ebisu, S. Interleukin-6 directly inhibits osteoclast differentiation by suppressing receptor activator of NF-kappaB signaling pathways. J. Biol. Chem. 2008, 283, 11535-11540. [CrossRef]

74. Wu, Q.; Zhou, X.; Huang, D.; Ji, Y.; Kang, F. IL-6 Enhances Osteocyte-Mediated Osteoclastogenesis by Promoting JAK2 and RANKL Activity In Vitro. Cell. Physiol. Biochem. 2017, 41, 1360-1369. [CrossRef]

75. Axmann, R.; Bohm, C.; Kronke, G.; Zwerina, J.; Smolen, J.; Schett, G. Inhibition of interleukin-6 receptor directly blocks osteoclast formation in vitro and in vivo. Arthritis Rheum. 2009, 60, 2747-2756. [CrossRef]

76. Luxenburg, C.; Winograd-Katz, S.; Addadi, L.; Geiger, B. Involvement of actin polymerization in podosome dynamics. J. Cell Sci. 2012, 125, 1666-1672. [CrossRef]

77. Georgess, D.; Machuca-Gayet, I.; Blangy, A.; Jurdic, P. Podosome organization drives osteoclast-mediated bone resorption. Cell Adhes. Migr. 2014, 8, 191-204. [CrossRef]

78. Jurdic, P.; Saltel, F.; Chabadel, A.; Destaing, O. Podosome and sealing zone: Specificity of the osteoclast model. Eur. J. Cell Biol. 2006, 85, 195-202. [CrossRef]

79. Park, J.H.; Jeong, E.; Lin, J.; Ko, R.; Kim, J.H.; Yi, S.; Choi, Y.; Kang, I.C.; Lee, D.; Lee, S.Y. RACK1 interaction with c-Src is essential for osteoclast function. Exp. Mol. Med. 2019, 51, 86. [CrossRef]

80. Soysa, N.S.; Alles, N. Osteoclast function and bone-resorbing activity: An overview. Biochem. Biophys. Res. Commun. 2016, 476, 115-120. [CrossRef] 
81. Feng, X.; Teitelbaum, S.L. Osteoclasts: New Insights. Bone Res. 2013, 1, 11-26. [CrossRef]

82. Blair, H.C.; Teitelbaum, S.L.; Tan, H.L.; Koziol, C.M.; Schlesinger, P.H. Passive chloride permeability charge coupled to $\mathrm{H}(+)$-ATPase of avian osteoclast ruffled membrane. Am. J. Physiol. 1991, 260, C1315-C1324. [CrossRef]

83. Dai, R.; Wu, Z.; Chu, H.Y.; Lu, J.; Lyu, A.; Liu, J.; Zhang, G. Cathepsin K: The Action in and Beyond Bone. Front. Cell Dev. Biol. 2020, 8, 433. [CrossRef]

84. Christensen, J.; Shastri, V.P. Matrix-metalloproteinase-9 is cleaved and activated by cathepsin K. BMC Res. Notes 2015, 8, 322. [CrossRef]

85. Zhu, L.; Tang, Y.; Li, X.Y.; Keller, E.T.; Yang, J.; Cho, J.S.; Feinberg, T.Y.; Weiss, S.J. Osteoclast-mediated bone resorption is controlled by a compensatory network of secreted and membrane-tethered metalloproteinases. Sci. Transl. Med. 2020, 12. [CrossRef]

86. Siddiqui, J.A.; Partridge, N.C. Physiological Bone Remodeling: Systemic Regulation and Growth Factor Involvement. Physiology 2016, 31, 233-245. [CrossRef]

87. Gu, G.; Mulari, M.; Peng, Z.; Hentunen, T.A.; Vaananen, H.K. Death of osteocytes turns off the inhibition of osteoclasts and triggers local bone resorption. Biochem. Biophys. Res. Commun. 2005, 335, 1095-1101. [CrossRef]

88. Hedgecock, N.L.; Hadi, T.; Chen, A.A.; Curtiss, S.B.; Martin, R.B.; Hazelwood, S.J. Quantitative regional associations between remodeling, modeling, and osteocyte apoptosis and density in rabbit tibial midshafts. Bone 2007, 40, 627-637. [CrossRef]

89. Batoon, L.; Millard, S.M.; Raggatt, L.J.; Pettit, A.R. Osteomacs and Bone Regeneration. Curr. Osteoporos. Rep. 2017, 15, 385-395. [CrossRef]

90. Sapir-Koren, R.; Livshits, G. Osteocyte control of bone remodeling: Is sclerostin a key molecular coordinator of the balanced bone resorption-formation cycles? Osteoporos. Int. 2014, 25, 2685-2700. [CrossRef]

91. Kular, J.; Tickner, J.; Chim, S.M.; Xu, J. An overview of the regulation of bone remodelling at the cellular level. Clin. Biochem. 2012, 45, 863-873. [CrossRef]

92. Winkler, D.G.; Sutherland, M.K.; Geoghegan, J.C.; Yu, C.; Hayes, T.; Skonier, J.E.; Shpektor, D.; Jonas, M.; Kovacevich, B.R.; Staehling-Hampton, K.; et al. Osteocyte control of bone formation via sclerostin, a novel BMP antagonist. EMBO J. 2003, 22, 6267-6276. [CrossRef]

93. Balemans, W.; Ebeling, M.; Patel, N.; Van Hul, E.; Olson, P.; Dioszegi, M.; Lacza, C.; Wuyts, W.; Van Den Ende, J.; Willems, P.; et al. Increased bone density in sclerosteosis is due to the deficiency of a novel secreted protein (SOST). Hum. Mol. Genet. 2001, 10, 537-543. [CrossRef]

94. Balemans, W.; Patel, N.; Ebeling, M.; Van Hul, E.; Wuyts, W.; Lacza, C.; Dioszegi, M.; Dikkers, F.G.; Hildering, P.; Willems, P.J.; et al. Identification of a $52 \mathrm{~kb}$ deletion downstream of the SOST gene in patients with van Buchem disease. J. Med. Genet. 2002, 39, 91-97. [CrossRef]

95. Chen, X.; Wang, Z.; Duan, N.; Zhu, G.; Schwarz, E.M.; Xie, C. Osteoblast-osteoclast interactions. Connect. Tissue Res. 2018, 59, 99-107. [CrossRef]

96. Ono, T.; Hayashi, M.; Sasaki, F.; Nakashima, T. RANKL biology: Bone metabolism, the immune system, and beyond. Inflamm. Regen. 2020, 40, 2. [CrossRef]

97. Sanchez, C.; Gabay, O.; Salvat, C.; Henrotin, Y.E.; Berenbaum, F. Mechanical loading highly increases IL-6 production and decreases OPG expression by osteoblasts. Osteoarthr. Cartil. 2009, 17, 473-481. [CrossRef]

98. Kogawa, M.; Khalid, K.A.; Wijenayaka, A.R.; Ormsby, R.T.; Evdokiou, A.; Anderson, P.H.; Findlay, D.M.; Atkins, G.J. Recombinant sclerostin antagonizes effects of ex vivo mechanical loading in trabecular bone and increases osteocyte lacunar size. Am. J. Physiol. Cell Physiol. 2018, 314, C53-C61. [CrossRef]

99. Hayashi, M.; Nakashima, T.; Taniguchi, M.; Kodama, T.; Kumanogoh, A.; Takayanagi, H. Osteoprotection by semaphorin 3A. Nature 2012, 485, 69-74. [CrossRef]

100. Negishi-Koga, T.; Shinohara, M.; Komatsu, N.; Bito, H.; Kodama, T.; Friedel, R.H.; Takayanagi, H. Suppression of bone formation by osteoclastic expression of semaphorin 4D. Nat. Med. 2011, 17, 1473-1480. [CrossRef]

101. Tonna, S.; Takyar, F.M.; Vrahnas, C.; Crimeen-Irwin, B.; Ho, P.W.; Poulton, I.J.; Brennan, H.J.; McGregor, N.E.; Allan, E.H.; Nguyen, H.; et al. EphrinB2 signaling in osteoblasts promotes bone mineralization by preventing apoptosis. FASEB J. 2014, 28, 4482-4496. [CrossRef]

102. Zhao, C.; Irie, N.; Takada, Y.; Shimoda, K.; Miyamoto, T.; Nishiwaki, T.; Suda, T.; Matsuo, K. Bidirectional ephrinB2-EphB4 signaling controls bone homeostasis. Cell Metab. 2006, 4, 111-121. [CrossRef] 
103. Gerstenfeld, L.C.; Cullinane, D.M.; Barnes, G.L.; Graves, D.T.; Einhorn, T.A. Fracture healing as a post-natal developmental process: Molecular, spatial, and temporal aspects of its regulation. J. Cell. Biochem. 2003, 88, 873-884. [CrossRef]

104. Dimitriou, R.; Tsiridis, E.; Giannoudis, P.V. Current concepts of molecular aspects of bone healing. Injury 2005, 36, 1392-1404. [CrossRef]

105. Burska, A.N.; Giannoudis, P.V.; Tan, B.H.; Ilas, D.; Jones, E.; Ponchel, F. Dynamics of Early Signalling Events during Fracture Healing and Potential Serum Biomarkers of Fracture Non-Union in Humans. J. Clin. Med. 2020, 9, 492. [CrossRef]

106. Schmidt-Bleek, K.; Schell, H.; Kolar, P.; Pfaff, M.; Perka, C.; Buttgereit, F.; Duda, G.; Lienau, J. Cellular composition of the initial fracture hematoma compared to a muscle hematoma: A study in sheep. J. Orthop. Res. 2009, 27, 1147-1151. [CrossRef]

107. Schmidt-Bleek, K.; Schell, H.; Lienau, J.; Schulz, N.; Hoff, P.; Pfaff, M.; Schmidt, G.; Martin, C.; Perka, C.; Buttgereit, F.; et al. Initial immune reaction and angiogenesis in bone healing. J. Tissue Eng. Regen. Med. 2014, 8, 120-130. [CrossRef]

108. Stefanowski, J.; Lang, A.; Rauch, A.; Aulich, L.; Kohler, M.; Fiedler, A.F.; Buttgereit, F.; Schmidt-Bleek, K.; Duda, G.N.; Gaber, T.; et al. Spatial Distribution of Macrophages During Callus Formation and Maturation Reveals Close Crosstalk Between Macrophages and Newly Forming Vessels. Front. Immunol. 2019, 10, 2588. [CrossRef]

109. Einhorn, T.A. The Cell and Molecular Biology of Fracture Healing. Clin. Orthop. Relat. Res. 1998, 355, S7-S21. [CrossRef]

110. Ahmed, Y.A.; Tatarczuch, L.; Pagel, C.N.; Davies, H.M.; Mirams, M.; Mackie, E.J. Physiological death of hypertrophic chondrocytes. Osteoarthr. Cartil. 2007, 15, 575-586. [CrossRef]

111. de Larco, J.E.; Todaro, G.J. Growth factors from murine sarcoma virus-transformed cells. Proc. Natl. Acad. Sci. USA 1978, 75, 4001-4005. [CrossRef]

112. Roberts, A.B.; Anzano, M.A.; Lamb, L.C.; Smith, J.M.; Sporn, M.B. New class of transforming growth factors potentiated by epidermal growth factor: Isolation from non-neoplastic tissues. Proc. Natl. Acad. Sci. USA 1981, 78, 5339-5343. [CrossRef]

113. Moses, H.L.; Branum, E.L.; Proper, J.A.; Robinson, R.A. Transforming Growth Factor Production by Chemically Transformed Cells. Cancer Res. 1981, 41, 2842-2848.

114. Roberts, A.B.; Frolik, C.A.; Anzano, M.A.; Sporn, M.B. Transforming growth factors from neoplastic and nonneoplastic tissues. Fed. Proc. 1983, 42, 2621-2626.

115. Fujii, D.; Brissenden, J.E.; Derynck, R.; Francke, U. Transforming growth factor beta gene maps to human chromosome 19 long arm and to mouse chromosome 7. Somat. Cell Mol. Genet. 1986, 12, 281-288. [CrossRef]

116. Barton, D.E.; Foellmer, B.E.; Du, J.; Tamm, J.; Derynck, R.; Francke, U. Chromosomal mapping of genes for transforming growth factors beta 2 and beta 3 in man and mouse: Dispersion of TGF-beta gene family. Oncogene Res. 1988, 3, 323-331.

117. ten Dijke, P.; Geurts van Kessel, A.H.; Foulkes, J.G.; Le Beau, M.M. Transforming growth factor type beta 3 maps to human chromosome 14, region q23-q24. Oncogene 1988, 3, 721-724.

118. Gentry, L.E.; Nash, B.W. The pro domain of pre-pro-transforming growth factor beta 1 when independently expressed is a functional binding protein for the mature growth factor. Biochemistry 1990, 29, 6851-6857. [CrossRef]

119. Derynck, R.; Jarrett, J.A.; Chen, E.Y.; Eaton, D.H.; Bell, J.R.; Assoian, R.K.; Roberts, A.B.; Sporn, M.B.; Goeddel, D.V. Human transforming growth factor-beta complementary DNA sequence and expression in normal and transformed cells. Nature 1985, 316, 701-705. [CrossRef]

120. Shi, M.; Zhu, J.; Wang, R.; Chen, X.; Mi, L.; Walz, T.; Springer, T.A. Latent TGF-beta structure and activation. Nature 2011, 474, 343-349. [CrossRef]

121. Mi, L.Z.; Brown, C.T.; Gao, Y.; Tian, Y.; Le, V.Q.; Walz, T.; Springer, T.A. Structure of bone morphogenetic protein 9 procomplex. Proc. Natl. Acad. Sci. USA 2015, 112, 3710-3715. [CrossRef]

122. Aluwihare, P.; Mu, Z.; Zhao, Z.; Yu, D.; Weinreb, P.H.; Horan, G.S.; Violette, S.M.; Munger, J.S. Mice that lack activity of alphavbeta6- and alphavbeta8-integrins reproduce the abnormalities of Tgfb1- and Tgfb3-null mice. J. Cell Sci. 2009, 122, 227-232. [CrossRef]

123. Marquardt, H.; Lioubin, M.N.; Ikeda, T. Complete amino acid sequence of human transforming growth factor type beta 2. J. Biol. Chem. 1987, 262, 12127-12131. 
124. Yue, J.; Mulder, K.M. Transforming growth factor- $\beta$ signal transduction in epithelial cells. Pharmacol. Ther. 2001, 91, 1-34. [CrossRef]

125. Kulkarni, A.B.; Huh, C.G.; Becker, D.; Geiser, A.; Lyght, M.; Flanders, K.C.; Roberts, A.B.; Sporn, M.B.; Ward, J.M.; Karlsson, S. Transforming growth factor beta 1 null mutation in mice causes excessive inflammatory response and early death. Proc. Natl. Acad. Sci. USA 1993, 90, 770-774. [CrossRef]

126. Proetzel, G.; Pawlowski, S.A.; Wiles, M.V.; Yin, M.; Boivin, G.P.; Howles, P.N.; Ding, J.; Ferguson, M.W.; Doetschman, T. Transforming growth factor-beta 3 is required for secondary palate fusion. Nat. Genet. 1995, 11, 409-414. [CrossRef]

127. Sanford, L.P.; Ormsby, I.; Gittenberger-de Groot, A.C.; Sariola, H.; Friedman, R.; Boivin, G.P.; Cardell, E.L.; Doetschman, T. TGFbeta2 knockout mice have multiple developmental defects that are non-overlapping with other TGFbeta knockout phenotypes. Development 1997, 124, 2659-2670.

128. Arai, D.; Hayakawa, K.; Ohgane, J.; Hirosawa, M.; Nakao, Y.; Tanaka, S.; Shiota, K. An epigenetic regulatory element of the Nodal gene in the mouse and human genomes. Mech. Dev. 2015, 136, 143-154. [CrossRef]

129. Bodenstine, T.M.; Chandler, G.S.; Seftor, R.E.; Seftor, E.A.; Hendrix, M.J. Plasticity underlies tumor progression: Role of Nodal signaling. Cancer Metastasis Rev. 2016, 35, 21-39. [CrossRef]

130. Vale, W.; Rivier, J.; Vaughan, J.; McClintock, R.; Corrigan, A.; Woo, W.; Karr, D.; Spiess, J. Purification and characterization of an FSH releasing protein from porcine ovarian follicular fluid. Nature 1986, 321, 776-779. [CrossRef]

131. Pauklin, S.; Vallier, L. Activin/Nodal signalling in stem cells. Development 2015, 142, 607-619. [CrossRef]

132. Wang, X.; Fischer, G.; Hyvonen, M. Structure and activation of pro-activin A. Nat. Commun. 2016, 7, 12052. [CrossRef]

133. Bloise, E.; Ciarmela, P.; Dela Cruz, C.; Luisi, S.; Petraglia, F.; Reis, F.M. Activin A in Mammalian Physiology. Physiol. Rev. 2019, 99, 739-780. [CrossRef]

134. Jhaveri, S.; Erzurumlu, R.S.; Chiaia, N.; Kumar, T.R.; Matzuk, M.M. Defective whisker follicles and altered brainstem patterns in activin and follistatin knockout mice. Mol. Cell. Neurosci. 1998, 12, 206-219. [CrossRef]

135. Matzuk, M.M.; Kumar, T.R.; Vassalli, A.; Bickenbach, J.R.; Roop, D.R.; Jaenisch, R.; Bradley, A. Functional analysis of activins during mammalian development. Nature 1995, 374, 354-356. [CrossRef]

136. Urist, M.R. Bone: Formation by autoinduction. Science 1965, 150, 893-899. [CrossRef]

137. Wozney, J.M.; Rosen, V.; Celeste, A.J.; Mitsock, L.M.; Whitters, M.J.; Kriz, R.W.; Hewick, R.M.; Wang, E.A. Novel regulators of bone formation: Molecular clones and activities. Science 1988, 242, 1528-1534. [CrossRef]

138. Ozkaynak, E.; Rueger, D.C.; Drier, E.A.; Corbett, C.; Ridge, R.J.; Sampath, T.K.; Oppermann, H. OP-1 cDNA encodes an osteogenic protein in the TGF-beta family. EMBO J. 1990, 9, 2085-2093. [CrossRef]

139. Kingsley, D.M. The TGF-beta superfamily: New members, new receptors, and new genetic tests of function in different organisms. Genes Dev. 1994, 8, 133-146. [CrossRef]

140. Brown, M.A.; Zhao, Q.; Baker, K.A.; Naik, C.; Chen, C.; Pukac, L.; Singh, M.; Tsareva, T.; Parice, Y.; Mahoney, A.; et al. Crystal structure of BMP-9 and functional interactions with pro-region and receptors. J. Biol. Chem. 2005, 280, 25111-25118. [CrossRef]

141. Zhang, L.; Luo, Q.; Shu, Y.; Zeng, Z.; Huang, B.; Feng, Y.; Zhang, B.; Wang, X.; Lei, Y.; Ye, Z.; et al. Transcriptomic landscape regulated by the 14 types of bone morphogenetic proteins (BMPs) in lineage commitment and differentiation of mesenchymal stem cells (MSCs). Genes Dis. 2019, 6, 258-275. [CrossRef]

142. Daluiski, A.; Engstrand, T.; Bahamonde, M.E.; Gamer, L.W.; Agius, E.; Stevenson, S.L.; Cox, K.; Rosen, V.; Lyons, K.M. Bone morphogenetic protein-3 is a negative regulator of bone density. Nat. Genet. 2001, 27, 84-88. [CrossRef]

143. Wu, F.J.; Lin, T.Y.; Sung, L.Y.; Chang, W.F.; Wu, P.C.; Luo, C.W. BMP8A sustains spermatogenesis by activating both SMAD1/5/8 and SMAD2/3 in spermatogonia. Sci. Signal. 2017, 10. [CrossRef]

144. Chen, H.; Brady Ridgway, J.; Sai, T.; Lai, J.; Warming, S.; Chen, H.; Roose-Girma, M.; Zhang, G.; Shou, W.; Yan, M. Context-dependent signaling defines roles of BMP9 and BMP10 in embryonic and postnatal development. Proc. Natl. Acad. Sci. USA 2013, 110, 11887-11892. [CrossRef]

145. Bidart, M.; Ricard, N.; Levet, S.; Samson, M.; Mallet, C.; David, L.; Subileau, M.; Tillet, E.; Feige, J.J.; Bailly, S. BMP9 is produced by hepatocytes and circulates mainly in an active mature form complexed to its prodomain. Cell. Mol. Life Sci. 2012, 69, 313-324. [CrossRef] 
146. Neugebauer, J.M.; Kwon, S.; Kim, H.S.; Donley, N.; Tilak, A.; Sopory, S.; Christian, J.L. The prodomain of BMP4 is necessary and sufficient to generate stable BMP4/7 heterodimers with enhanced bioactivity in vivo. Proc. Natl. Acad. Sci. USA 2015, 112, E2307-E2316. [CrossRef]

147. Wohl, A.P.; Troilo, H.; Collins, R.F.; Baldock, C.; Sengle, G. Extracellular Regulation of Bone Morphogenetic Protein Activity by the Microfibril Component Fibrillin-1. J. Biol. Chem. 2016, 291, 12732-12746. [CrossRef]

148. Gregory, K.E.; Ono, R.N.; Charbonneau, N.L.; Kuo, C.L.; Keene, D.R.; Bachinger, H.P.; Sakai, L.Y. The prodomain of BMP-7 targets the BMP-7 complex to the extracellular matrix. J. Biol. Chem. 2005, 280, 27970-27980. [CrossRef]

149. Salmon, R.M.; Guo, J.; Wood, J.H.; Tong, Z.; Beech, J.S.; Lawera, A.; Yu, M.; Grainger, D.J.; Reckless, J.; Morrell, N.W.; et al. Molecular basis of ALK1-mediated signalling by BMP9/BMP10 and their prodomain-bound forms. Nat. Commun. 2020, 11, 1621. [CrossRef]

150. Cheng, H.; Jiang, W.; Phillips, F.M.; Haydon, R.C.; Peng, Y.; Zhou, L.; Luu, H.H.; An, N.; Breyer, B.; Vanichakarn, P.; et al. Osteogenic activity of the fourteen types of human bone morphogenetic proteins (BMPs). J. Bone Joint Surg. Am. 2003, 85, 1544-1552. [CrossRef]

151. Kang, Q.; Sun, M.H.; Cheng, H.; Peng, Y.; Montag, A.G.; Deyrup, A.T.; Jiang, W.; Luu, H.H.; Luo, J.; Szatkowski, J.P.; et al. Characterization of the distinct orthotopic bone-forming activity of 14 BMPs using recombinant adenovirus-mediated gene delivery. Gene Ther. 2004, 11, 1312-1320. [CrossRef]

152. Wutzl, A.; Rauner, M.; Seemann, R.; Millesi, W.; Krepler, P.; Pietschmann, P.; Ewers, R. Bone morphogenetic proteins 2, 5, and 6 in combination stimulate osteoblasts but not osteoclasts in vitro. J. Orthop. Res. 2010, 28, 1431-1439. [CrossRef]

153. Cui, J.; Zhang, W.; Huang, E.; Wang, J.; Liao, J.; Li, R.; Yu, X.; Zhao, C.; Zeng, Z.; Shu, Y.; et al. BMP9-induced osteoblastic differentiation requires functional Notch signaling in mesenchymal stem cells. Lab. Investig. 2019, 99, 58-71. [CrossRef]

154. Zhang, Y.; Yang, W.; Devit, A.; van den Beucken, J. Efficiency of coculture with angiogenic cells or physiological BMP-2 administration on improving osteogenic differentiation and bone formation of MSCs. J. Biomed. Mater. Res. A 2019, 107, 643-653. [CrossRef]

155. Cao, X.; Chen, D. The BMP signaling and in vivo bone formation. Gene 2005, 357, 1-8. [CrossRef]

156. Winnier, G.; Blessing, M.; Labosky, P.A.; Hogan, B.L. Bone morphogenetic protein-4 is required for mesoderm formation and patterning in the mouse. Genes Dev. 1995, 9, 2105-2116. [CrossRef]

157. Lawson, K.A.; Dunn, N.R.; Roelen, B.A.; Zeinstra, L.M.; Davis, A.M.; Wright, C.V.; Korving, J.P.; Hogan, B.L. $\mathrm{Bmp} 4$ is required for the generation of primordial germ cells in the mouse embryo. Genes Dev. 1999, 13, 424-436. [CrossRef]

158. Luo, G.; Hofmann, C.; Bronckers, A.L.; Sohocki, M.; Bradley, A.; Karsenty, G. BMP-7 is an inducer of nephrogenesis, and is also required for eye development and skeletal patterning. Genes Dev. 1995, 9, 2808-2820. [CrossRef]

159. Gipson, G.R.; Goebel, E.J.; Hart, K.N.; Kappes, E.C.; Kattamuri, C.; McCoy, J.C.; Thompson, T.B. Structural perspective of BMP ligands and signaling. Bone 2020, 140, 115549. [CrossRef]

160. Sieber, C.; Kopf, J.; Hiepen, C.; Knaus, P. Recent advances in BMP receptor signaling. Cytokine Growth Factor Rev. 2009, 20, 343-355. [CrossRef]

161. Greenwald, J.; Groppe, J.; Gray, P.; Wiater, E.; Kwiatkowski, W.; Vale, W.; Choe, S. The BMP7/ActRII Extracellular Domain Complex Provides New Insights into the Cooperative Nature of Receptor Assembly. Mol. Cell 2003, 11, 605-617. [CrossRef]

162. Yadin, D.; Knaus, P.; Mueller, T.D. Structural insights into BMP receptors: Specificity, activation and inhibition. Cytokine Growth Factor Rev. 2016, 27, 13-34. [CrossRef]

163. Grafe, I.; Alexander, S.; Peterson, J.R.; Snider, T.N.; Levi, B.; Lee, B.; Mishina, Y. TGF-beta Family Signaling in Mesenchymal Differentiation. Cold Spring Harb. Perspect. Biol. 2018, 10. [CrossRef]

164. van den Bosch, M.H.; Blom, A.B.; van Lent, P.L.; van Beuningen, H.M.; Davidson, E.N.B.; van der Kraan, P.M.; van den Berg, W.B. Canonical Wnt signaling skews TGF-beta signaling in chondrocytes towards signaling via ALK1 and Smad 1/5/8. Cell Signal. 2014, 26, 951-958. [CrossRef]

165. Olsen, O.E.; Hella, H.; Elsaadi, S.; Jacobi, C.; Martinez-Hackert, E.; Holien, T. Activins as Dual Specificity TGF-beta Family Molecules: SMAD-Activation via Activin- and BMP-Type 1 Receptors. Biomolecules 2020, 10, 519. [CrossRef]

166. Schmierer, B.; Hill, C.S. TGFbeta-SMAD signal transduction: Molecular specificity and functional flexibility. Nat. Rev. Mol. Cell Biol. 2007, 8, 970-982. [CrossRef] 
167. Wang, R.N.; Green, J.; Wang, Z.; Deng, Y.; Qiao, M.; Peabody, M.; Zhang, Q.; Ye, J.; Yan, Z.; Denduluri, S.; et al. Bone Morphogenetic Protein (BMP) signaling in development and human diseases. Genes Dis. 2014, 1, 87-105. [CrossRef]

168. Brazil, D.P.; Church, R.H.; Surae, S.; Godson, C.; Martin, F. BMP signalling: Agony and antagony in the family. Trends Cell Biol. 2015, 25, 249-264. [CrossRef]

169. Okadome, T.; Yamashita, H.; Franzén, P.; Morén, A.; Heldin, C.H.; Miyazono, K. Distinct roles of the intracellular domains of transforming growth factor-beta type I and type II receptors in signal transduction. J. Biol. Chem. 1994, 269, 30753-30756.

170. Hinck, A.P. Structural studies of the TGF-betas and their receptors-Insights into evolution of the TGF-beta superfamily. FEBS Lett. 2012, 586, 1860-1870. [CrossRef]

171. Fong, D.; Bisson, M.; Laberge, G.; McManus, S.; Grenier, G.; Faucheux, N.; Roux, S. Bone morphogenetic protein-9 activates Smad and ERK pathways and supports human osteoclast function and survival in vitro. Cell Signal. 2013, 25, 717-728. [CrossRef]

172. Kaneko, H.; Arakawa, T.; Mano, H.; Kaneda, T.; Ogasawara, A.; Nakagawa, M.; Toyama, Y.; Yabe, Y.; Kumegawa, M.; Hakeda, Y. Direct stimulation of osteoclastic bone resorption by bone morphogenetic protein (BMP)-2 and expression of BMP receptors in mature osteoclasts. Bone 2000, 27, 479-486. [CrossRef]

173. Chen, G.; Deng, C.; Li, Y.P. TGF-beta and BMP signaling in osteoblast differentiation and bone formation. Int. J. Biol. Sci. 2012, 8, 272-288. [CrossRef]

174. Gratchev, A. TGF-beta signalling in tumour associated macrophages. Immunobiology 2017, $222,75-81$. [CrossRef]

175. Ebisawa, T.; Tada, K.; Kitajima, I.; Tojo, K.; Sampath, T.K.; Kawabata, M.; Miyazono, K.; Imamura, T. Characterization of bone morphogenetic protein-6 signaling pathways in osteoblast differentiation. J. Cell Sci. 1999, 112, 3519-3527.

176. Gratchev, A.; Kzhyshkowska, J.; Kannookadan, S.; Ochsenreiter, M.; Popova, A.; Yu, X.; Mamidi, S.; Stonehouse-Usselmann, E.; Muller-Molinet, I.; Gooi, L.; et al. Activation of a TGF-beta-specific multistep gene expression program in mature macrophages requires glucocorticoid-mediated surface expression of TGF-beta receptor II. J. Immunol. 2008, 180, 6553-6565. [CrossRef]

177. Ota, K.; Quint, P.; Ruan, M.; Pederson, L.; Westendorf, J.J.; Khosla, S.; Oursler, M.J. TGF-beta induces Wnt10b in osteoclasts from female mice to enhance coupling to osteoblasts. Endocrinology 2013, 154, 3745-3752. [CrossRef]

178. Meurer, S.K.; Esser, M.; Tihaa, L.; Weiskirchen, R. BMP-7/TGF-beta1 signalling in myoblasts: Components involved in signalling and BMP-7-dependent blockage of TGF-beta-mediated CTGF expression. Eur. J. Cell Biol. 2012, 91, 450-463. [CrossRef]

179. Suzuki, E.; Ochiai-Shino, H.; Aoki, H.; Onodera, S.; Saito, A.; Saito, A.; Azuma, T. Akt activation is required for TGF-beta1-induced osteoblast differentiation of MC3T3-E1 pre-osteoblasts. PLoS ONE 2014, 9, e112566. [CrossRef]

180. Sowa, H.; Kaji, H.; Yamaguchi, T.; Sugimoto, T.; Chihara, K. Activations of ERK1/2 and JNK by transforming growth factor beta negatively regulate Smad3-induced alkaline phosphatase activity and mineralization in mouse osteoblastic cells. J. Biol. Chem. 2002, 277, 36024-36031. [CrossRef]

181. Zhou, S. TGF-beta regulates beta-catenin signaling and osteoblast differentiation in human mesenchymal stem cells. J. Cell. Biochem. 2011, 112, 1651-1660. [CrossRef]

182. Liyun, G.; Xu, J.; Li, X.; Wang, T.; Wu, W.; Cao, J. 2,3,7,8-Tetrachlorodibenzo-p-Dioxin and TGF-beta3 Mediated-Mouse Embryonic Palatal Mesenchymal Cells. Dose Response 2018, 16. [CrossRef]

183. Arita, N.A.; Pelaez, D.; Cheung, H.S. Activation of the extracellular signal-regulated kinases 1 and 2 (ERK1/2) is needed for the TGFbeta-induced chondrogenic and osteogenic differentiation of mesenchymal stem cells. Biochem. Biophys. Res. Commun. 2011, 405, 564-569. [CrossRef]

184. Kajita, T.; Ariyoshi, W.; Okinaga, T.; Mitsugi, S.; Tominaga, K.; Nishihara, T. Mechanisms involved in enhancement of osteoclast formation by activin-A. J. Cell. Biochem. 2018, 119, 6974-6985. [CrossRef]

185. Murase, Y.; Okahashi, N.; Koseki, T.; Itoh, K.; Udagawa, N.; Hashimoto, O.; Sugino, H.; Noguchi, T.; Nishihara, T. Possible involvement of protein kinases and Smad2 signaling pathways on osteoclast differentiation enhanced by activin A. J. Cell Physiol. 2001, 188, 236-242. [CrossRef] 
186. Zhang, Z.; Wang, J.; Chen, Y.; Suo, L.; Chen, H.; Zhu, L.; Wan, G.; Han, X. Activin a promotes myofibroblast differentiation of endometrial mesenchymal stem cells via STAT3-dependent Smad/CTGF pathway. Cell Commun. Signal. 2019, 17, 45. [CrossRef]

187. Broege, A.; Pham, L.; Jensen, E.D.; Emery, A.; Huang, T.H.; Stemig, M.; Beppu, H.; Petryk, A.; O'Connor, M.; Mansky, K.; et al. Bone morphogenetic proteins signal via SMAD and mitogen-activated protein (MAP) kinase pathways at distinct times during osteoclastogenesis. J. Biol. Chem. 2013, 288, 37230-37240. [CrossRef]

188. Mandal, C.C.; Das, F.; Ganapathy, S.; Harris, S.E.; Choudhury, G.G.; Ghosh-Choudhury, N. Bone Morphogenetic Protein-2 (BMP-2) Activates NFATc1 Transcription Factor via an Autoregulatory Loop Involving Smad/Akt/Ca2+ Signaling. J. Biol. Chem. 2016, 291, 1148-1161. [CrossRef]

189. Xiao, M.; Yao, B.; Zhang, B.D.; Bai, Y.; Sui, W.; Wang, W.; Yu, Q. Stromal-derived Factor-1alpha signaling is involved in bone morphogenetic protein-2-induced odontogenic differentiation of stem cells from apical papilla via the Smad and Erk signaling pathways. Exp. Cell Res. 2019, 381, 39-49. [CrossRef]

190. Drevelle, O.; Daviau, A.; Lauzon, M.A.; Faucheux, N. Effect of BMP-2 and/or BMP-9 on preosteoblasts attached to polycaprolactone functionalized by adhesive peptides derived from bone sialoprotein. Biomaterials 2013, 34, 1051-1062. [CrossRef]

191. Lauzon, M.A.; Daviau, A.; Drevelle, O.; Marcos, B.; Faucheux, N. Identification of a growth factor mimicking the synergistic effect of fetal bovine serum on BMP-9 cell response. Tissue Eng. Part A 2014, 20, 2524-2535. [CrossRef]

192. Lauzon, M.A.; Drevelle, O.; Daviau, A.; Faucheux, N. Effects of BMP-9 and BMP-2 on the PI3K/Akt Pathway in MC3T3-E1 Preosteoblasts. Tissue Eng. Part A 2016, 22, 1075-1085. [CrossRef]

193. Aoki, H.; Fujii, M.; Imamura, T.; Yagi, K.; Takehara, K.; Kato, M.; Miyazono, K. Synergistic effects of different bone morphogenetic protein type I receptors on alkaline phosphatase induction. J. Cell Sci. 2001, $114,1483-1489$.

194. Lichtner, B.; Knaus, P.; Lehrach, H.; Adjaye, J. BMP10 as a potent inducer of trophoblast differentiation in human embryonic and induced pluripotent stem cells. Biomaterials 2013, 34, 9789-9802. [CrossRef]

195. Vijayan, V.; Gupta, S.; Gupta, S. Bone morphogenetic protein-5, a key molecule that mediates differentiation in MC3T3E1 osteoblast cell line. Biofactors 2017, 43, 558-566. [CrossRef]

196. Moore, R.K.; Otsuka, F.; Shimasaki, S. Molecular basis of bone morphogenetic protein-15 signaling in granulosa cells. J. Biol. Chem. 2003, 278, 304-310. [CrossRef]

197. Cheng, A.; Gustafson, A.R.; Schaner Tooley, C.E.; Zhang, M. BMP-9 dependent pathways required for the chondrogenic differentiation of pluripotent stem cells. Differentiation 2016, 92, 298-305. [CrossRef]

198. Chang, H.M.; Cheng, J.C.; Klausen, C.; Leung, P.C. BMP15 suppresses progesterone production by down-regulating StAR via ALK3 in human granulosa cells. Mol. Endocrinol. 2013, 27, 2093-2104. [CrossRef]

199. Nakamura, K.; Shirai, T.; Morishita, S.; Uchida, S.; Saeki-Miura, K.; Makishima, F. p38 mitogen-activated protein kinase functionally contributes to chondrogenesis induced by growth/differentiation factor-5 in ATDC5 cells. Exp. Cell Res. 1999, 250, 351-363. [CrossRef]

200. Wang, S.S.; Huang, H.Y.; Chen, S.Z.; Li, X.; Zhang, W.T.; Tang, Q.Q. Gdf6 induces commitment of pluripotent mesenchymal C3H10T1/2 cells to the adipocyte lineage. FEBS J. 2013, 280, 2644-2651. [CrossRef]

201. Andersson, O.; Reissmann, E.; Ibanez, C.F. Growth differentiation factor 11 signals through the transforming growth factor-beta receptor ALK5 to regionalize the anterior-posterior axis. EMBO Rep. 2006, 7, 831-837. [CrossRef]

202. Matsumoto, Y.; Otsuka, F.; Hino, J.; Miyoshi, T.; Takano, M.; Miyazato, M.; Makino, H.; Kangawa, K. Bone morphogenetic protein-3b (BMP-3b) inhibits osteoblast differentiation via Smad2/3 pathway by counteracting Smad1/5/8 signaling. Mol. Cell Endocrinol. 2012, 350, 78-86. [CrossRef]

203. Nickel, J.; Ten Dijke, P.; Mueller, T.D. TGF-beta family co-receptor function and signaling. Acta Biochim. Biophys. Sin. 2018, 50, 12-36. [CrossRef]

204. Moustakas, A.; Lin, H.Y.; Henis, Y.I.; Plamondon, J.; O'Connor-McCourt, M.D.; Lodish, H.F. The transforming growth factor beta receptors types I, II, and III form hetero-oligomeric complexes in the presence of ligand. J. Biol. Chem. 1993, 268, 22215-22218.

205. Esparza-Lopez, J.; Montiel, J.L.; Vilchis-Landeros, M.M.; Okadome, T.; Miyazono, K.; Lopez-Casillas, F. Ligand binding and functional properties of betaglycan, a co-receptor of the transforming growth factor-beta superfamily. Specialized binding regions for transforming growth factor-beta and inhibin A. J. Biol. Chem. 2001, 276, 14588-14596. [CrossRef] 
206. Bilandzic, M.; Stenvers, K.L. Betaglycan: A multifunctional accessory. Mol. Cell. Endocrinol. 2011, 339, 180-189. [CrossRef]

207. Cheifetz, S.; Bellón, T.; Calés, C.; Vera, S.; Bernabeu, C.; Massagué, J.; Letarte, M. Endoglin is a component of the transforming growth factor-beta receptor system in human endothelial cells. J. Biol. Chem. 1992, 267, 19027-19030.

208. Castonguay, R.; Werner, E.D.; Matthews, R.G.; Presman, E.; Mulivor, A.W.; Solban, N.; Sako, D.; Pearsall, R.S.; Underwood, K.W.; Seehra, J.; et al. Soluble endoglin specifically binds bone morphogenetic proteins 9 and 10 via its orphan domain, inhibits blood vessel formation, and suppresses tumor growth. J. Biol. Chem. 2011, 286, 30034-30046. [CrossRef]

209. Saito, T.; Bokhove, M.; Croci, R.; Zamora-Caballero, S.; Han, L.; Letarte, M.; de Sanctis, D.; Jovine, L. Structural Basis of the Human Endoglin-BMP9 Interaction: Insights into BMP Signaling and HHT1. Cell Rep. 2017, 19, 1917-1928. [CrossRef]

210. Shi, Y.; Wang, Y.-F.; Jayaraman, L.; Yang, H.; Massagué, J.; Pavletich, N.P. Crystal Structure of a Smad MH1 Domain Bound to DNA. Cell 1998, 94, 585-594. [CrossRef]

211. Lo, R.S.; Chen, Y.G.; Shi, Y.; Pavletich, N.P.; Massague, J. The L3 loop: A structural motif determining specific interactions between SMAD proteins and TGF-beta receptors. EMBO J. 1998, 17, 996-1005. [CrossRef]

212. Xu, P.; Lin, X.; Feng, X.H. Posttranslational Regulation of Smads. Cold Spring Harb. Perspect. Biol. 2016, 8, a022087. [CrossRef]

213. Makkar, P.; Metpally, R.P.; Sangadala, S.; Reddy, B.V. Modeling and analysis of MH1 domain of Smads and their interaction with promoter DNA sequence motif. J. Mol. Graph. Model. 2009, 27, 803-812. [CrossRef]

214. Massague, J.; Seoane, J.; Wotton, D. Smad transcription factors. Genes Dev. 2005, 19, 2783-2810. [CrossRef]

215. Kretzschmar, M.; Doody, J.; Massague, J. Opposing BMP and EGF signalling pathways converge on the TGF-beta family mediator Smad1. Nature 1997, 389, 618-622. [CrossRef]

216. Hassanisaber, H.; Rouleau, L.; Faucheux, N. Effect of BMP-9 on endothelial cells and its role in atherosclerosis. Front. Biosci. 2019, 24, 994-1023. [CrossRef]

217. Wu, M.; Chen, G.; Li, Y.P. TGF-beta and BMP signaling in osteoblast, skeletal development, and bone formation, homeostasis and disease. Bone Res. 2016, 4, 16009. [CrossRef]

218. Lawera, A.; Tong, Z.; Thorikay, M.; Redgrave, R.E.; Cai, J.; van Dinther, M.; Morrell, N.W.; Afink, G.B.; Charnock-Jones, D.S.; Arthur, H.M.; et al. Role of soluble endoglin in BMP9 signaling. Proc. Natl. Acad. Sci. USA 2019, 116, 17800-17808. [CrossRef]

219. Huse, M.; Muir, T.W.; Xu, L.; Chen, Y.-G.; Kuriyan, J.; Massagué, J. The TGF $\beta$ Receptor Activation Process. Mol. Cell 2001, 8, 671-682. [CrossRef]

220. Tzavlaki, K.; Moustakas, A. TGF-beta Signaling. Biomolecules 2020, 10, 487. [CrossRef]

221. Lin, H.Y.; Moustakas, A.; Knaus, P.; Wells, R.G.; Henis, Y.I.; Lodish, H.F. The soluble exoplasmic domain of the type II transforming growth factor (TGF)-beta receptor. A heterogeneously glycosylated protein with high affinity and selectivity for TGF-beta ligands. J. Biol. Chem. 1995, 270, 2747-2754. [CrossRef]

222. Mathews, L.S. Activin receptors and cellular signaling by the receptor serine kinase family. Endocr. Rev. 1994, 15, 310-325. [CrossRef]

223. Bernard, D.J.; Lee, K.B.; Santos, M.M. Activin B can signal through both ALK4 and ALK7 in gonadotrope cells. Reprod. Biol. Endocrinol. 2006, 4, 52. [CrossRef]

224. Shi, Y.; Massagué, J. Mechanisms of TGF- $\beta$ Signaling from Cell Membrane to the Nucleus. Cell 2003, 113, 685-700. [CrossRef]

225. Persson, U.; Izumi, H.; Souchelnytskyi, S.; Itoh, S.; Grimsby, S.; Engström, U.; Heldin, C.-H.; Funa, K.; ten Dijke, P. The L45 loop in type I receptors for TGF- $\beta$ family members is a critical determinant in specifying Smad isoform activation. FEBS Lett. 1998, 434, 83-87. [CrossRef]

226. Qin, B.Y.; Chacko, B.M.; Lam, S.S.; de Caestecker, M.P.; Correia, J.J.; Lin, K. Structural Basis of Smad1 Activation by Receptor Kinase Phosphorylation. Mol. Cell 2001, 8, 1303-1312. [CrossRef]

227. Tsukazaki, T.; Chiang, T.A.; Davison, A.F.; Attisano, L.; Wrana, J.L. SARA, a FYVE Domain Protein that Recruits Smad2 to the TGF $\beta$ Receptor. Cell 1998, 95, 779-791. [CrossRef]

228. Itoh, F.; Divecha, N.; Brocks, L.; Oomen, L.; Janssen, H.; Calafat, J.; Itoh, S.; Dijke Pt, P. The FYVE domain in Smad anchor for receptor activation (SARA) is sufficient for localization of SARA in early endosomes and regulates TGF-beta/Smad signalling. Genes Cells 2002, 7, 321-331. [CrossRef] 
229. Miyazawa, K.; Shinozaki, M.; Hara, T.; Furuya, T.; Miyazono, K. Two major Smad pathways in TGF-beta superfamily signalling. Genes Cells 2002, 7, 1191-1204. [CrossRef]

230. Hua, X.; Miller, Z.A.; Benchabane, H.; Wrana, J.L.; Lodish, H.F. Synergism between transcription factors TFE3 and Smad3 in transforming growth factor-beta-induced transcription of the Smad7 gene. J. Biol. Chem. 2000, 275, 33205-33208. [CrossRef]

231. Aragon, E.; Wang, Q.; Zou, Y.; Morgani, S.M.; Ruiz, L.; Kaczmarska, Z.; Su, J.; Torner, C.; Tian, L.; Hu, J.; et al. Structural basis for distinct roles of SMAD2 and SMAD3 in FOXH1 pioneer-directed TGF-beta signaling. Genes Dev. 2019, 33, 1506-1524. [CrossRef]

232. Nohe, A.; Hassel, S.; Ehrlich, M.; Neubauer, F.; Sebald, W.; Henis, Y.I.; Knaus, P. The mode of bone morphogenetic protein (BMP) receptor oligomerization determines different BMP-2 signaling pathways. J. Biol. Chem. 2002, 277, 5330-5338. [CrossRef]

233. Ehrlich, M. Endocytosis and trafficking of BMP receptors: Regulatory mechanisms for fine-tuning the signaling response in different cellular contexts. Cytokine Growth Factor Rev. 2016, 27, 35-42. [CrossRef]

234. Heinecke, K.; Seher, A.; Schmitz, W.; Mueller, T.D.; Sebald, W.; Nickel, J. Receptor oligomerization and beyond: A case study in bone morphogenetic proteins. BMC Biol. 2009, 7, 59. [CrossRef] [PubMed]

235. Scharpfenecker, M.; van Dinther, M.; Liu, Z.; van Bezooijen, R.L.; Zhao, Q.; Pukac, L.; Lowik, C.W.; ten Dijke, P. BMP-9 signals via ALK1 and inhibits bFGF-induced endothelial cell proliferation and VEGF-stimulated angiogenesis. J. Cell Sci. 2007, 120, 964-972. [CrossRef] [PubMed]

236. Luo, J.; Tang, M.; Huang, J.; He, B.C.; Gao, J.L.; Chen, L.; Zuo, G.W.; Zhang, W.; Luo, Q.; Shi, Q.; et al. TGFbeta/BMP type I receptors ALK1 and ALK2 are essential for BMP9-induced osteogenic signaling in mesenchymal stem cells. J. Biol. Chem. 2010, 285, 29588-29598. [CrossRef] [PubMed]

237. Luther, G.; Wagner, E.R.; Zhu, G.; Kang, Q.; Luo, Q.; Lamplot, J.; Bi, Y.; Luo, X.; Luo, J.; Teven, C.; et al. BMP-9 induced osteogenic differentiation of mesenchymal stem cells: Molecular mechanism and therapeutic potential. Curr. Gene Ther. 2011, 11, 229-240. [CrossRef] [PubMed]

238. Zhang, J.; Li, L. BMP signaling and stem cell regulation. Dev. Biol. 2005, 284, 1-11. [CrossRef]

239. Matsubara, T.; Kida, K.; Yamaguchi, A.; Hata, K.; Ichida, F.; Meguro, H.; Aburatani, H.; Nishimura, R.; Yoneda, T. BMP2 regulates Osterix through Msx2 and Runx2 during osteoblast differentiation. J. Biol. Chem. 2008, 283, 29119-29125. [CrossRef]

240. Onichtchouk, D.; Chen, Y.G.; Dosch, R.; Gawantka, V.; Delius, H.; Massague, J.; Niehrs, C. Silencing of TGF-beta signalling by the pseudoreceptor BAMBI. Nature 1999, 401, 480-485. [CrossRef]

241. Gray, P.C.; Harrison, C.A.; Vale, W. Cripto forms a complex with activin and type II activin receptors and can block activin signaling. Proc. Natl. Acad. Sci. USA 2003, 100, 5193-5198. [CrossRef]

242. Seemann, P.; Brehm, A.; Konig, J.; Reissner, C.; Stricker, S.; Kuss, P.; Haupt, J.; Renninger, S.; Nickel, J.; Sebald, W.; et al. Mutations in GDF5 reveal a key residue mediating BMP inhibition by NOGGIN. PLoS Genet. 2009, 5, e1000747. [CrossRef] [PubMed]

243. Feeley, B.T.; Krenek, L.; Liu, N.; Hsu, W.K.; Gamradt, S.C.; Schwarz, E.M.; Huard, J.; Lieberman, J.R. Overexpression of noggin inhibits BMP-mediated growth of osteolytic prostate cancer lesions. Bone 2006, 38, 154-166. [CrossRef] [PubMed]

244. Mulloy, B.; Rider, C.C. The Bone Morphogenetic Proteins and Their Antagonists. Vitam. Horm. 2015, 99, 63-90. [CrossRef] [PubMed]

245. Sidis, Y.; Mukherjee, A.; Keutmann, H.; Delbaere, A.; Sadatsuki, M.; Schneyer, A. Biological activity of follistatin isoforms and follistatin-like-3 is dependent on differential cell surface binding and specificity for activin, myostatin, and bone morphogenetic proteins. Endocrinology 2006, 147, 3586-3597. [CrossRef]

246. Miyazawa, K.; Miyazono, K. Regulation of TGF-beta Family Signaling by Inhibitory Smads. Cold Spring Harb. Perspect. Biol. 2017, 9, a022095. [CrossRef]

247. Kamiya, Y.; Miyazono, K.; Miyazawa, K. Smad7 inhibits transforming growth factor-beta family type i receptors through two distinct modes of interaction. J. Biol. Chem. 2010, 285, 30804-30813. [CrossRef]

248. Goto, K.; Kamiya, Y.; Imamura, T.; Miyazono, K.; Miyazawa, K. Selective inhibitory effects of Smad6 on bone morphogenetic protein type I receptors. J. Biol. Chem. 2007, 282, 20603-20611. [CrossRef]

249. Mochizuki, T.; Miyazaki, H.; Hara, T.; Furuya, T.; Imamura, T.; Watabe, T.; Miyazono, K. Roles for the $\mathrm{MH} 2$ domain of Smad7 in the specific inhibition of transforming growth factor-beta superfamily signaling. J. Biol. Chem. 2004, 279, 31568-31574. [CrossRef] 
250. Hanyu, A.; Ishidou, Y.; Ebisawa, T.; Shimanuki, T.; Imamura, T.; Miyazono, K. The N domain of Smad7 is essential for specific inhibition of transforming growth factor-beta signaling. J. Cell Biol. 2001, 155, 1017-1027. [CrossRef]

251. Koganti, P.; Levy-Cohen, G.; Blank, M. Smurfs in Protein Homeostasis, Signaling, and Cancer. Front. Oncol. 2018, 8, 295. [CrossRef]

252. Yan, X.; Lin, Z.; Chen, F.; Zhao, X.; Chen, H.; Ning, Y.; Chen, Y.G. Human BAMBI cooperates with Smad7 to inhibit transforming growth factor-beta signaling. J. Biol. Chem. 2009, 284, 30097-30104. [CrossRef]

253. Tsukamoto, S.; Mizuta, T.; Fujimoto, M.; Ohte, S.; Osawa, K.; Miyamoto, A.; Yoneyama, K.; Murata, E.; Machiya, A.; Jimi, E.; et al. Smad9 is a new type of transcriptional regulator in bone morphogenetic protein signaling. Sci. Rep. 2014, 4, 7596. [CrossRef]

254. Katagiri, T.; Tsukamoto, S.; Kuratani, M. Heterotopic bone induction via BMP signaling: Potential therapeutic targets for fibrodysplasia ossificans progressiva. Bone 2018, 109, 241-250. [CrossRef]

255. Bellavia, D.; De Luca, A.; Carina, V.; Costa, V.; Raimondi, L.; Salamanna, F.; Alessandro, R.; Fini, M.; Giavaresi, G. Deregulated miRNAs in bone health: Epigenetic roles in osteoporosis. Bone 2019, 122, 52-75. [CrossRef] [PubMed]

256. Niu, G.; Li, B.; Sun, L.; An, C. MicroRNA-153 inhibits osteosarcoma cells proliferation and invasion by targeting TGF-beta2. PLoS ONE 2015, 10, e0119225. [CrossRef] [PubMed]

257. Li, Z.; Hassan, M.Q.; Jafferji, M.; Aqeilan, R.I.; Garzon, R.; Croce, C.M.; van Wijnen, A.J.; Stein, J.L.; Stein, G.S.; Lian, J.B. Biological functions of miR-29b contribute to positive regulation of osteoblast differentiation. J. Biol. Chem. 2009, 284, 15676-15684. [CrossRef]

258. Liu, M.; Xiusheng, H.; Xiao, X.; Wang, Y. Overexpression of miR-422a inhibits cell proliferation and invasion, and enhances chemosensitivity in osteosarcoma cells. Oncol. Rep. 2016, 36, 3371-3378. [CrossRef] [PubMed]

259. Wu, T.; Zhou, H.; Hong, Y.; Li, J.; Jiang, X.; Huang, H. miR-30 family members negatively regulate osteoblast differentiation. J. Biol. Chem. 2012, 287, 7503-7511. [CrossRef]

260. Li, Z.; Hassan, M.Q.; Volinia, S.; van Wijnen, A.J.; Stein, J.L.; Croce, C.M.; Lian, J.B.; Stein, G.S. A microRNA signature for a BMP2-induced osteoblast lineage commitment program. Proc. Natl. Acad. Sci. USA 2008, 105, 13906-13911. [CrossRef]

261. Zhang, J.F.; Fu, W.M.; He, M.L.; Xie, W.D.; Lv, Q.; Wan, G.; Li, G.; Wang, H.; Lu, G.; Hu, X.; et al. MiRNA-20a promotes osteogenic differentiation of human mesenchymal stem cells by co-regulating BMP signaling. RNA Biol. 2011, 8, 829-838. [CrossRef]

262. Iwasaki, S.; Iguchi, M.; Watanabe, K.; Hoshino, R.; Tsujimoto, M.; Kohno, M. Specific activation of the p38 mitogen-activated protein kinase signaling pathway and induction of neurite outgrowth in PC12 cells by bone morphogenetic protein-2. J. Biol. Chem. 1999, 274, 26503-26510. [CrossRef] [PubMed]

263. Guicheux, J.; Lemonnier, J.; Ghayor, C.; Suzuki, A.; Palmer, G.; Caverzasio, J. Activation of p38 mitogen-activated protein kinase and c-Jun-NH2-terminal kinase by BMP-2 and their implication in the stimulation of osteoblastic cell differentiation. J. Bone Miner. Res. 2003, 18, 2060-2068. [CrossRef] [PubMed]

264. Arnott, J.A.; Zhang, X.; Sanjay, A.; Owen, T.A.; Smock, S.L.; Rehman, S.; DeLong, W.G.; Safadi, F.F.; Popoff, S.N. Molecular requirements for induction of CTGF expression by TGF-beta1 in primary osteoblasts. Bone 2008, 42, 871-885. [CrossRef]

265. Li, H.; Zhao, D.; Wang, S.; Ding, J.; Zhao, L. Bone morphogenetic protein9 promotes the differentiation of mouse spleen macrophages into osteoclasts via the ALK1 receptor and ERK 1/2 pathways in vitro. Mol. Med. Rep. 2016, 14, 4545-4550. [CrossRef] [PubMed]

266. Lee, K.S.; Hong, S.H.; Bae, S.C. Both the Smad and p38 MAPK pathways play a crucial role in Runx2 expression following induction by transforming growth factor-beta and bone morphogenetic protein. Oncogene 2002, 21, 7156-7163. [CrossRef]

267. Celil, A.B.; Campbell, P.G. BMP-2 and insulin-like growth factor-I mediate Osterix (Osx) expression in human mesenchymal stem cells via the MAPK and protein kinase D signaling pathways. J. Biol. Chem. 2005, 280, 31353-31359. [CrossRef]

268. Ge, C.; Xiao, G.; Jiang, D.; Yang, Q.; Hatch, N.E.; Roca, H.; Franceschi, R.T. Identification and functional characterization of ERK/MAPK phosphorylation sites in the Runx2 transcription factor. J. Biol. Chem. 2009, 284, 32533-32543. [CrossRef] 
269. Ulsamer, A.; Ortuno, M.J.; Ruiz, S.; Susperregui, A.R.; Osses, N.; Rosa, J.L.; Ventura, F. BMP-2 induces Osterix expression through up-regulation of Dlx 5 and its phosphorylation by p38. J. Biol. Chem. 2008, 283, 3816-3826. [CrossRef]

270. Ortuno, M.J.; Ruiz-Gaspa, S.; Rodriguez-Carballo, E.; Susperregui, A.R.; Bartrons, R.; Rosa, J.L.; Ventura, F. p38 regulates expression of osteoblast-specific genes by phosphorylation of osterix. J. Biol. Chem. 2010, 285, 31985-31994. [CrossRef]

271. Huang, Y.F.; Lin, J.J.; Lin, C.H.; Su, Y.; Hung, S.C. c-Jun N-terminal kinase 1 negatively regulates osteoblastic differentiation induced by BMP2 via phosphorylation of Runx2 at Ser104. J. Bone Miner. Res. 2012, 27, 1093-1105. [CrossRef]

272. Aubin, J.; Davy, A.; Soriano, P. In vivo convergence of BMP and MAPK signaling pathways: Impact of differential Smad1 phosphorylation on development and homeostasis. Genes Dev. 2004, 18, 1482-1494. [CrossRef] [PubMed]

273. Nickel, J.; Mueller, T.D. Specification of BMP Signaling. Cells 2019, 8, 1579. [CrossRef] [PubMed]

274. Maeda, K.; Kobayashi, Y.; Koide, M.; Uehara, S.; Okamoto, M.; Ishihara, A.; Kayama, T.; Saito, M.; Marumo, K. The Regulation of Bone Metabolism and Disorders by Wnt Signaling. Int. J. Mol. Sci. 2019, 20, 5525. [CrossRef]

275. Wang, N.; Liu, W.; Tan, T.; Dong, C.Q.; Lin, D.Y.; Zhao, J.; Yu, C.; Luo, X.J. Notch signaling negatively regulates BMP9-induced osteogenic differentiation of mesenchymal progenitor cells by inhibiting JunB expression. Oncotarget 2017, 8, 109661-109674. [CrossRef] [PubMed]

276. Principe, D.R.; Doll, J.A.; Bauer, J.; Jung, B.; Munshi, H.G.; Bartholin, L.; Pasche, B.; Lee, C.; Grippo, P.J. TGF-beta: Duality of function between tumor prevention and carcinogenesis. J. Natl. Cancer Inst. 2014, 106, djt369. [CrossRef]

277. LaFoya, B.; Munroe, J.A.; Mia, M.M.; Detweiler, M.A.; Crow, J.J.; Wood, T.; Roth, S.; Sharma, B.; Albig, A.R. Notch: A multi-functional integrating system of microenvironmental signals. Dev. Biol. 2016, 418, 227-241. [CrossRef]

278. Nusse, R.; Varmus, H.E. Many tumors induced by the mouse mammary tumor virus contain a provirus integrated in the same region of the host genome. Cell 1982, 31, 99-109. [CrossRef]

279. Rijsewijk, F.; Schuermann, M.; Wagenaar, E.; Parren, P.; Weigel, D.; Nusse, R. The Drosophila homology of the mouse mammary oncogene int-1 is identical to the segment polarity gene wingless. Cell 1987, 50, 649-657. [CrossRef]

280. Kikuchi, A.; Yamamoto, H.; Sato, A.; Matsumoto, S. New insights into the mechanism of Wnt signaling pathway activation. Int. Rev. Cell Mol. Biol. 2011, 291, 21-71. [CrossRef]

281. Ng, L.F.; Kaur, P.; Bunnag, N.; Suresh, J.; Sung, I.C.H.; Tan, Q.H.; Gruber, J.; Tolwinski, N.S. WNT Signaling in Disease. Cells 2019, 8, 826. [CrossRef]

282. Nusse, R.; Clevers, H. Wnt/beta-Catenin Signaling, Disease, and Emerging Therapeutic Modalities. Cell 2017, 169, 985-999. [CrossRef] [PubMed]

283. Yost, C.; Torres, M.; Miller, J.R.; Huang, E.; Kimelman, D.; Moon, R.T. The axis-inducing activity, stability, and subcellular distribution of beta-catenin is regulated in Xenopus embryos by glycogen synthase kinase 3. Genes Dev. 1996, 10, 1443-1454. [CrossRef] [PubMed]

284. Hart, M.; Concordet, J.P.; Lassot, I.; Albert, I.; del los Santos, R.; Durand, H.; Perret, C.; Rubinfeld, B.; Margottin, F.; Benarous, R.; et al. The F-box protein $\beta$-TrCP associates with phosphorylated $\beta$-catenin and regulates its activity in the cell. Curr. Biol. 1999, 9, 207-211. [CrossRef]

285. Cruciat, C.M.; Niehrs, C. Secreted and transmembrane wnt inhibitors and activators. Cold Spring Harb. Perspect. Biol. 2013, 5, a015081. [CrossRef]

286. Krishnan, V.; Bryant, H.U.; Macdougald, O.A. Regulation of bone mass by Wnt signaling. J. Clin. Investig. 2006, 116, 1202-1209. [CrossRef]

287. Zhao, C.; Yu, T.; Dou, Q.; Guo, Y.; Yang, X.; Chen, Y. Knockout of TLR4 promotes fracture healing by activating Wnt/beta-catenin signaling pathway. Pathol. Res. Pract. 2020, 216, 152766. [CrossRef]

288. Morsczeck, C.; Reck, A.; Reichert, T.E. WNT3A and the induction of the osteogenic differentiation in adipose tissue derived mesenchymal stem cells. Tissue Cell 2017, 49, 489-494. [CrossRef]

289. Glass, D.A., 2nd; Bialek, P.; Ahn, J.D.; Starbuck, M.; Patel, M.S.; Clevers, H.; Taketo, M.M.; Long, F.; McMahon, A.P.; Lang, R.A.; et al. Canonical Wnt signaling in differentiated osteoblasts controls osteoclast differentiation. Dev. Cell 2005, 8, 751-764. [CrossRef] 
290. Inkson, C.A.; Ono, M.; Kuznetsov, S.A.; Fisher, L.W.; Robey, P.G.; Young, M.F. TGF-beta1 and WISP-1/CCN-4 can regulate each other's activity to cooperatively control osteoblast function. J. Cell. Biochem. 2008, 104, 1865-1878. [CrossRef]

291. Gaur, T.; Lengner, C.J.; Hovhannisyan, H.; Bhat, R.A.; Bodine, P.V.; Komm, B.S.; Javed, A.; van Wijnen, A.J.; Stein, J.L.; Stein, G.S.; et al. Canonical WNT signaling promotes osteogenesis by directly stimulating Runx2 gene expression. J. Biol. Chem. 2005, 280, 33132-33140. [CrossRef]

292. Guo, X.; Ramirez, A.; Waddell, D.S.; Li, Z.; Liu, X.; Wang, X.F. Axin and GSK3- control Smad3 protein stability and modulate TGF- signaling. Genes Dev. 2008, 22, 106-120. [CrossRef]

293. Fuentealba, L.C.; Eivers, E.; Ikeda, A.; Hurtado, C.; Kuroda, H.; Pera, E.M.; De Robertis, E.M. Integrating patterning signals: Wnt/GSK3 regulates the duration of the BMP/Smad1 signal. Cell 2007, 131, 980-993. [CrossRef] [PubMed]

294. Tang, N.; Song, W.X.; Luo, J.; Luo, X.; Chen, J.; Sharff, K.A.; Bi, Y.; He, B.C.; Huang, J.Y.; Zhu, G.H.; et al. BMP-9-induced osteogenic differentiation of mesenchymal progenitors requires functional canonical Wnt/beta-catenin signalling. J. Cell Mol. Med. 2009, 13, 2448-2464. [CrossRef] [PubMed]

295. Rodriguez-Carballo, E.; Ulsamer, A.; Susperregui, A.R.; Manzanares-Cespedes, C.; Sanchez-Garcia, E.; Bartrons, R.; Rosa, J.L.; Ventura, F. Conserved regulatory motifs in osteogenic gene promoters integrate cooperative effects of canonical Wnt and BMP pathways. J. Bone Miner. Res. 2011, 26, 718-729. [CrossRef] [PubMed]

296. Rawadi, G.; Vayssiere, B.; Dunn, F.; Baron, R.; Roman-Roman, S. BMP-2 controls alkaline phosphatase expression and osteoblast mineralization by a Wnt autocrine loop. J. Bone Miner. Res. 2003, 18, 1842-1853. [CrossRef]

297. Strutt, D.I.; Weber, U.; Mlodzik, M. The role of RhoA in tissue polarity and Frizzled signalling. Nature 1997, 387, 292-295. [CrossRef]

298. Schambony, A.; Wedlich, D. Wnt-5A/Ror2 regulate expression of XPAPC through an alternative noncanonical signaling pathway. Dev. Cell 2007, 12, 779-792. [CrossRef]

299. Uehara, S.; Udagawa, N.; Kobayashi, Y. Non-canonical Wnt signals regulate cytoskeletal remodeling in osteoclasts. Cell. Mol. Life Sci. 2018, 75, 3683-3692. [CrossRef]

300. Uehara, S.; Udagawa, N.; Mukai, H.; Ishihara, A.; Maeda, K.; Yamashita, T.; Murakami, K.; Nishita, M.; Nakamura, T.; Kato, S.; et al. Protein kinase N3 promotes bone resorption by osteoclasts in response to Wnt5a-Ror2 signaling. Sci. Signal. 2017, 10, eaan0023. [CrossRef]

301. Sheldahl, L.C.; Park, M.; Malbon, C.C.; Moon, R.T. Protein kinase C is differentially stimulated by Wnt and Frizzled homologs in aG-protein-dependent manner. Curr. Biol. 1999, 9, 695-698, S1. [CrossRef]

302. Dejmek, J.; Safholm, A.; Kamp Nielsen, C.; Andersson, T.; Leandersson, K. Wnt-5a/Ca2+-induced NFAT activity is counteracted by Wnt-5a/Yes-Cdc42-casein kinase 1alpha signaling in human mammary epithelial cells. Mol. Cell. Biol. 2006, 26, 6024-6036. [CrossRef]

303. Hogan, P.G.; Chen, L.; Nardone, J.; Rao, A. Transcriptional regulation by calcium, calcineurin, and NFAT. Genes Dev. 2003, 17, 2205-2232. [CrossRef]

304. Zunke, F.; Rose-John, S. The shedding protease ADAM17: Physiology and pathophysiology. Biochim. Biophys. Acta Mol. Cell Res. 2017, 1864, 2059-2070. [CrossRef] [PubMed]

305. Liu, C.; Xu, P.; Lamouille, S.; Xu, J.; Derynck, R. TACE-mediated ectodomain shedding of the type I TGF-beta receptor downregulates TGF-beta signaling. Mol. Cell 2009, 35, 26-36. [CrossRef] [PubMed]

306. Kopan, R.; Ilagan, M.X. The canonical Notch signaling pathway: Unfolding the activation mechanism. Cell 2009, 137, 216-233. [CrossRef] [PubMed]

307. Kopan, R. Notch signaling. Cold Spring Harb. Perspect. Biol. 2012, 4. [CrossRef]

308. Regan, J.; Long, F. Notch signaling and bone remodeling. Curr. Osteoporos. Rep. 2013, 11, 126-129. [CrossRef]

309. Pereira, R.M.; Delany, A.M.; Durant, D.; Canalis, E. Cortisol regulates the expression of Notch in osteoblasts. J. Cell. Biochem. 2002, 85, 252-258. [CrossRef]

310. Ashley, J.W.; Ahn, J.; Hankenson, K.D. Notch signaling promotes osteoclast maturation and resorptive activity. J. Cell. Biochem. 2015, 116, 2598-2609. [CrossRef]

311. Sekine, C.; Koyanagi, A.; Koyama, N.; Hozumi, K.; Chiba, S.; Yagita, H. Differential regulation of osteoclastogenesis by Notch2/Delta-like 1 and Notch1/Jagged1 axes. Arthritis Res. Ther. 2012, 14, R45. [CrossRef] 
312. Tezuka, K.; Yasuda, M.; Watanabe, N.; Morimura, N.; Kuroda, K.; Miyatani, S.; Hozumi, N. Stimulation of osteoblastic cell differentiation by Notch. J. Bone Miner. Res. 2002, 17, 231-239. [CrossRef] [PubMed]

313. Yamada, T.; Yamazaki, H.; Yamane, T.; Yoshino, M.; Okuyama, H.; Tsuneto, M.; Kurino, T.; Hayashi, S.; Sakano, S. Regulation of osteoclast development by Notch signaling directed to osteoclast precursors and through stromal cells. Blood 2003, 101, 2227-2234. [CrossRef] [PubMed]

314. He, Y.; Zou, L. Notch-1 inhibition reduces proliferation and promotes osteogenic differentiation of bone marrow mesenchymal stem cells. Exp. Ther. Med. 2019, 18, 1884-1890. [CrossRef]

315. AlMuraikhi, N.; Ali, D.; Vishnubalaji, R.; Manikandan, M.; Atteya, M.; Siyal, A.; Alfayez, M.; Aldahmash, A.; Kassem, M.; Alajez, N.M. Notch Signaling Inhibition by LY411575 Attenuates Osteoblast Differentiation and Decreased Ectopic Bone Formation Capacity of Human Skeletal (Mesenchymal) Stem Cells. Stem Cells Int. 2019, 2019, 3041262. [CrossRef] [PubMed]

316. Goel, P.N.; Moharrer, Y.; Hebb, J.H.; Egol, A.J.; Kaur, G.; Hankenson, K.D.; Ahn, J.; Ashley, J.W. Suppression of Notch Signaling in Osteoclasts Improves Bone Regeneration and Healing. J. Orthop. Res. 2019, 37, 2089-2103. [CrossRef] [PubMed]

317. Cao, J.; Wei, Y.; Lian, J.; Yang, L.; Zhang, X.; Xie, J.; Liu, Q.; Luo, J.; He, B.; Tang, M. Notch signaling pathway promotes osteogenic differentiation of mesenchymal stem cells by enhancing BMP9/Smad signaling. Int. J. Mol. Med. 2017, 40, 378-388. [CrossRef]

318. Khorsand, B.; Elangovan, S.; Hong, L.; Dewerth, A.; Kormann, M.S.; Salem, A.K. A Comparative Study of the Bone Regenerative Effect of Chemically Modified RNA Encoding BMP-2 or BMP-9. AAPS J. 2017, 19, 438-446. [CrossRef]

319. Alinejad, Y.; Lauzon, M.A.; Grenier, G.; Balg, F.; Faucheux, N. Both Human Hematoma Punctured from Pelvic Fractures and Serum Increase Muscle Resident Stem Cells Response to BMP9: A Multivariate Statistical Approach. J. Clin. Med. 2020, 9, 1175. [CrossRef]

320. Zheng, Y.; Wu, G.; Zhao, J.; Wang, L.; Sun, P.; Gu, Z. rhBMP2/7 heterodimer: An osteoblastogenesis inducer of not higher potency but lower effective concentration compared with rhBMP2 and rhBMP7 homodimers. Tissue Eng. Part A 2010, 16, 879-887. [CrossRef]

321. Loozen, L.D.; Vandersteen, A.; Kragten, A.H.; Oner, F.C.; Dhert, W.J.; Kruyt, M.C.; Alblas, J. Bone formation by heterodimers through non-viral gene delivery of BMP-2/6 and BMP-2/7. Eur. Cell Mater. 2018, 35, 195-208. [CrossRef]

322. Kaito, T.; Morimoto, T.; Mori, Y.; Kanayama, S.; Makino, T.; Takenaka, S.; Sakai, Y.; Otsuru, S.; Yoshioka, Y.; Yoshikawa, H. BMP-2/7 heterodimer strongly induces bone regeneration in the absence of increased soft tissue inflammation. Spine J. 2018, 18, 139-146. [CrossRef] [PubMed]

323. Miao, C.; Qin, D.; Cao, P.; Lu, P.; Xia, Y.; Li, M.; Sun, M.; Zhang, W.; Yang, F.; Zhang, Y.; et al. BMP2/7 heterodimer enhances osteogenic differentiation of rat BMSCs via ERK signaling compared with respective homodimers. J. Cell Biochem. 2018. [CrossRef] [PubMed]

324. Zhang, X.; Chen, S.; Liu, Y.; Zhang, P.; Ge, Y.; Guo, J.; Wu, G.; Zhou, Y. Heterodimeric BMP-2/7 exhibits different osteoinductive effects in human and murine cells. Growth Factors 2018, 36, 141-152. [CrossRef] [PubMed]

325. Lee, B.; Oh, Y.; Jo, S.; Kim, T.H.; Ji, J.D. A dual role of TGF-beta in human osteoclast differentiation mediated by Smad1 versus Smad3 signaling. Immunol. Lett. 2019, 206, 33-40. [CrossRef]

326. Zheng, Y.; Wang, L.; Zhang, X.; Zhang, X.; Gu, Z.; Wu, G. BMP2/7 heterodimer can modulate all cellular events of the in vitro RANKL-mediated osteoclastogenesis, respectively, in different dose patterns. Tissue Eng. Part A 2012, 18, 621-630. [CrossRef]

327. Yan, T.; Riggs, B.L.; Boyle, W.J.; Khosla, S. Regulation of osteoclastogenesis and RANK expression by TGF-beta1. J. Cell. Biochem. 2001, 83, 320-325. [CrossRef]

328. Quinn, J.M.; Itoh, K.; Udagawa, N.; Hausler, K.; Yasuda, H.; Shima, N.; Mizuno, A.; Higashio, K.; Takahashi, N.; Suda, T.; et al. Transforming growth factor beta affects osteoclast differentiation via direct and indirect actions. J. Bone Miner. Res. 2001, 16, 1787-1794. [CrossRef]

329. Karst, M.; Gorny, G.; Galvin, R.J.; Oursler, M.J. Roles of stromal cell RANKL, OPG, and M-CSF expression in biphasic TGF-beta regulation of osteoclast differentiation. J. Cell. Physiol. 2004, 200, 99-106. [CrossRef] [PubMed]

330. Houde, N.; Chamoux, E.; Bisson, M.; Roux, S. Transforming growth factor-beta1 (TGF-beta1) induces human osteoclast apoptosis by up-regulating Bim. J. Biol. Chem. 2009, 284, 23397-23404. [CrossRef] 
331. Jensen, E.D.; Pham, L.; Billington, C.J., Jr.; Espe, K.; Carlson, A.E.; Westendorf, J.J.; Petryk, A.; Gopalakrishnan, R.; Mansky, K. Bone morphogenic protein 2 directly enhances differentiation of murine osteoclast precursors. J. Cell. Biochem. 2010, 109, 672-682. [CrossRef]

332. Dankbar, B.; Fennen, M.; Brunert, D.; Hayer, S.; Frank, S.; Wehmeyer, C.; Beckmann, D.; Paruzel, P.; Bertrand, J.; Redlich, K.; et al. Myostatin is a direct regulator of osteoclast differentiation and its inhibition reduces inflammatory joint destruction in mice. Nat. Med. 2015, 21, 1085-1090. [CrossRef] [PubMed]

333. Itoh, K.; Udagawa, N.; Katagiri, T.; Iemura, S.; Ueno, N.; Yasuda, H.; Higashio, K.; Quinn, J.M.; Gillespie, M.T.; Martin, T.J.; et al. Bone morphogenetic protein 2 stimulates osteoclast differentiation and survival supported by receptor activator of nuclear factor-kappaB ligand. Endocrinology 2001, 142, 3656-3662. [CrossRef] [PubMed]

334. Cho, T.J.; Gerstenfeld, L.C.; Einhorn, T.A. Differential temporal expression of members of the transforming growth factor beta superfamily during murine fracture healing. J. Bone Miner. Res. 2002, 17, 513-520. [CrossRef] [PubMed]

335. Meyer, R.A., Jr.; Meyer, M.H.; Tenholder, M.; Wondracek, S.; Wasserman, R.; Garges, P. Gene Expression in Older Rats with Delayed Union of Femoral Fractures. JBJS 2003, 85, 1243-1254. [CrossRef] [PubMed]

336. Cottrell, J.A.; Keane, O.; Sutton Lin, S.; O'Connor, J.P. BMP-2 modulates expression of other growth factors in a rat fracture healing model. J. Appl. Biomed. 2014, 12, 127-135. [CrossRef]

337. Murata, M.; Huang, B.-Z.; Shibata, T.; Imai, S.; Nagal, N.; Arisue, M. Bone augmentation by recombinant human BMP-2 and collagen on adult rat parietal bone. Int. J. Oral Maxillofac. Surg. 1999, 28, 232-237. [CrossRef]

338. Antebi, Y.E.; Linton, J.M.; Klumpe, H.; Bintu, B.; Gong, M.; Su, C.; McCardell, R.; Elowitz, M.B. Combinatorial Signal Perception in the BMP Pathway. Cell 2017, 170, 1184-1196. [CrossRef] [PubMed]

339. Rasi Ghaemi, S.; Delalat, B.; Ceto, X.; Harding, F.J.; Tuke, J.; Voelcker, N.H. Synergistic influence of collagen I and BMP 2 drives osteogenic differentiation of mesenchymal stem cells: A cell microarray analysis. Acta Biomater. 2016, 34, 41-52. [CrossRef]

340. Sarahrudi, K.; Thomas, A.; Mousavi, M.; Kaiser, G.; Kottstorfer, J.; Kecht, M.; Hajdu, S.; Aharinejad, S. Elevated transforming growth factor-beta 1 (TGF-beta1) levels in human fracture healing. Injury 2011, 42, 833-837. [CrossRef]

341. Zimmermann, G.; Henle, P.; Kusswetter, M.; Moghaddam, A.; Wentzensen, A.; Richter, W.; Weiss, S. TGF-beta1 as a marker of delayed fracture healing. Bone 2005, 36, 779-785. [CrossRef]

342. Onishi, T.; Ishidou, Y.; Nagamine, T.; Yone, K.; Imamura, T.; Kato, M.; Sampath, T.K.; ten Dijke, P.; Sakou, T. Distinct and Overlapping Patterns of Localization of Bone Morphogenetic Protein (BMP) Family Members and a BMP Type II Receptor During Fracture Healing in Rats. Bone 1998, 22, 605-612. [CrossRef]

343. Kloen, P.; Di Paola, M.; Borens, O.; Richmond, J.; Perino, G.; Helfet, D.L.; Goumans, M.J. BMP signaling components are expressed in human fracture callus. Bone 2003, 33, 362-371. [CrossRef]

344. Gordon, K.J.; Blobe, G.C. Role of transforming growth factor-beta superfamily signaling pathways in human disease. Biochim. Biophys. Acta 2008, 1782, 197-228. [CrossRef] [PubMed]

345. Seeman, E. Pathogenesis of bone fragility in women and men. Lancet 2002, 359, 1841-1850. [CrossRef]

346. Hughes, D.E.; Dai, A.; Tiffee, J.C.; Li, H.H.; Mundy, G.R.; Boyce, B.F. Estrogen promotes apoptosis of murine osteoclasts mediated by TGF-b. Nat. Med. 1996, 2, 1132-1136. [CrossRef]

347. Kong, Y.Y.; Boyle, W.J.; Penninger, J.M. Osteoprotegerin ligand: A regulator of immune responses and bone physiology. Immunol. Today 2000, 21, 495-502. [CrossRef]

348. Walsh, M.C.; Choi, Y. Biology of the RANKL-RANK-OPG System in Immunity, Bone, and Beyond. Front. Immunol. 2014, 5, 511. [CrossRef]

349. Janssens, K.; ten Dijke, P.; Janssens, S.; Van Hul, W. Transforming growth factor-beta1 to the bone. Endocr. Rev. 2005, 26, 743-774. [CrossRef]

350. Ralston, S.H.; de Crombrugghe, B. Genetic regulation of bone mass and susceptibility to osteoporosis. Genes Dev. 2006, 20, 2492-2506. [CrossRef] [PubMed]

351. Grafe, I.; Yang, T.; Alexander, S.; Homan, E.P.; Lietman, C.; Jiang, M.M.; Bertin, T.; Munivez, E.; Chen, Y.; Dawson, B.; et al. Excessive transforming growth factor-beta signaling is a common mechanism in osteogenesis imperfecta. Nat. Med. 2014, 20, 670-675. [CrossRef]

352. Tauer, J.T.; Abdullah, S.; Rauch, F. Effect of Anti-TGF-beta Treatment in a Mouse Model of Severe Osteogenesis Imperfecta. J. Bone Miner. Res. 2019, 34, 207-214. [CrossRef] [PubMed] 
353. Buijs, J.T.; Stayrook, K.R.; Guise, T.A. The role of TGF-beta in bone metastasis: Novel therapeutic perspectives. Bonekey Rep. 2012, 1, 96. [CrossRef] [PubMed]

354. Clezardin, P. Pathophysiology of bone metastases from solid malignancies. Joint Bone Spine 2017, 84, 677-684. [CrossRef]

355. Kyle, R.A.; Rajkumar, S.V. Multiple myeloma. Blood 2008, 111, 2962-2972. [CrossRef]

356. Roux, S. Myeloma bone disease: Pathophysiology. Rev. Rhum. 2017, 84, 181-186.

357. Matsumoto, T.; Abe, M. TGF-beta-related mechanisms of bone destruction in multiple myeloma. Bone 2011, 48, 129-134. [CrossRef]

358. Lu, A.; Pallero, M.A.; Lei, W.; Hong, H.; Yang, Y.; Suto, M.J.; Murphy-Ullrich, J.E. Inhibition of Transforming Growth Factor-beta Activation Diminishes Tumor Progression and Osteolytic Bone Disease in Mouse Models of Multiple Myeloma. Am. J. Pathol. 2016, 186, 678-690. [CrossRef]

359. Terpos, E.; Kastritis, E.; Christoulas, D.; Gkotzamanidou, M.; Eleutherakis-Papaiakovou, E.; Kanellias, N.; Papatheodorou, A.; Dimopoulos, M.A. Circulating activin-A is elevated in patients with advanced multiple myeloma and correlates with extensive bone involvement and inferior survival; no alterations post-lenalidomide and dexamethasone therapy. Ann. Oncol. 2012, 23, 2681-2686. [CrossRef]

360. Vallet, S.; Mukherjee, S.; Vaghela, N.; Hideshima, T.; Fulciniti, M.; Pozzi, S.; Santo, L.; Cirstea, D.; Patel, K.; Sohani, A.R.; et al. Activin A promotes multiple myeloma-induced osteolysis and is a promising target for myeloma bone disease. Proc. Natl. Acad. Sci. USA 2010, 107, 5124-5129. [CrossRef]

361. Ruckle, J.; Jacobs, M.; Kramer, W.; Pearsall, A.E.; Kumar, R.; Underwood, K.W.; Seehra, J.; Yang, Y.; Condon, C.H.; Sherman, M.L. Single-dose, randomized, double-blind, placebo-controlled study of ACE-011 (ActRIIA-IgG1) in postmenopausal women. J. Bone Miner. Res. 2009, 24, 744-752. [CrossRef]

362. Abdulkadyrov, K.M.; Salogub, G.N.; Khuazheva, N.K.; Sherman, M.L.; Laadem, A.; Barger, R.; Knight, R.; Srinivasan, S.; Terpos, E. Sotatercept in patients with osteolytic lesions of multiple myeloma. Br. J. Haematol. 2014, 165, 814-823. [CrossRef] [PubMed]

363. Demirhan, O.; Turkmen, S.; Schwabe, G.C.; Soyupak, S.; Akgul, E.; Tastemir, D.; Karahan, D.; Mundlos, S.; Lehmann, K. A homozygous BMPR1B mutation causes a new subtype of acromesomelic chondrodysplasia with genital anomalies. J. Med. Genet. 2005, 42, 314-317. [CrossRef]

364. Shore, E.M.; Xu, M.; Feldman, G.J.; Fenstermacher, D.A.; Cho, T.J.; Choi, I.H.; Connor, J.M.; Delai, P.; Glaser, D.L.; LeMerrer, M.; et al. A recurrent mutation in the BMP type I receptor ACVR1 causes inherited and sporadic fibrodysplasia ossificans progressiva. Nat. Genet. 2006, 38, 525-527. [CrossRef] [PubMed]

365. Hildebrand, L.; Stange, K.; Deichsel, A.; Gossen, M.; Seemann, P. The Fibrodysplasia Ossificans Progressiva (FOP) mutation p.R206H in ACVR1 confers an altered ligand response. Cell Signal. 2017, 29, 23-30. [CrossRef]

366. Kaplan, F.S.; Al Mukaddam, M.; Stanley, A.; Towler, O.W.; Shore, E.M. Fibrodysplasia ossificans progressiva (FOP): A disorder of osteochondrogenesis. Bone 2020, 140, 115539. [CrossRef] [PubMed]

367. Kaplan, F.S.; Xu, M.; Seemann, P.; Connor, J.M.; Glaser, D.L.; Carroll, L.; Delai, P.; Fastnacht-Urban, E.; Forman, S.J.; Gillessen-Kaesbach, G.; et al. Classic and atypical fibrodysplasia ossificans progressiva (FOP) phenotypes are caused by mutations in the bone morphogenetic protein (BMP) type I receptor ACVR1. Hum. Mutat. 2009, 30, 379-390. [CrossRef]

368. Fukuda, T.; Kohda, M.; Kanomata, K.; Nojima, J.; Nakamura, A.; Kamizono, J.; Noguchi, Y.; Iwakiri, K.; Kondo, T.; Kurose, J.; et al. Constitutively activated ALK2 and increased SMAD1/5 cooperatively induce bone morphogenetic protein signaling in fibrodysplasia ossificans progressiva. J. Biol. Chem. 2009, 284, 7149-7156. [CrossRef] [PubMed]

369. Fiori, J.L.; Billings, P.C.; de la Pena, L.S.; Kaplan, F.S.; Shore, E.M. Dysregulation of the BMP-p38 MAPK signaling pathway in cells from patients with fibrodysplasia ossificans progressiva (FOP). J. Bone Miner. Res. 2006, 21, 902-909. [CrossRef] [PubMed]

370. Haupt, J.; Stanley, A.; McLeod, C.M.; Cosgrove, B.D.; Culbert, A.L.; Wang, L.; Mourkioti, F.; Mauck, R.L.; Shore, E.M. ACVR1(R206H) FOP mutation alters mechanosensing and tissue stiffness during heterotopic ossification. Mol. Biol. Cell 2019, 30, 17-29. [CrossRef] [PubMed]

371. Hatsell, S.J.; Idone, V.; Wolken, D.M.A.; Huang, L.; Kim, H.J.; Wang, L.; Wen, X.; Nannuru, K.C.; Jimenez, J.; Xie, L.; et al. ACVR1R206Hreceptor mutation causes fibrodysplasia ossificans progressiva by imparting responsiveness to activin A. Sci. Transl. Med. 2015, 7, 303ra137. [CrossRef] [PubMed]

372. Cohen, M.M., Jr. The new bone biology: Pathologic, molecular, and clinical correlates. Am. J. Med. Genet. A 2006, 140, 2646-2706. [CrossRef] [PubMed] 
373. Kang, H.; Jha, S.; Ivovic, A.; Fratzl-Zelman, N.; Deng, Z.; Mitra, A.; Cabral, W.A.; Hanson, E.P.; Lange, E.; Cowen, E.W.; et al. Somatic SMAD3-activating mutations cause melorheostosis by up-regulating the TGF-beta/SMAD pathway. J. Exp. Med. 2020, 217. [CrossRef] [PubMed]

374. Jha, S.; Fratzl-Zelman, N.; Roschger, P.; Papadakis, G.Z.; Cowen, E.W.; Kang, H.; Lehky, T.J.; Alter, K.; Deng, Z.; Ivovic, A.; et al. Distinct Clinical and Pathological Features of Melorheostosis Associated With Somatic MAP2K1 Mutations. J. Bone Miner. Res. 2019, 34, 145-156. [CrossRef]

375. Wozney, J.M. Overview of bone morphogenetic proteins. Spine 2002, 27, S2-S8. [CrossRef]

376. Maruoka, Y.; Oida, S.; Iimura, T.; Takeda, K.; Asahina, I.; Enomoto, S.; Sasaki, S. Production of functional human bone morphogenetic protein-2 using a baculovirus/Sf-9 insect cell system. Biochem. Mol. Biol. Int. 1995, 35, 957-963.

377. Karyagina, A.S.; Boksha, I.S.; Grunina, T.M.; Demidenko, A.V.; Poponova, M.S.; Sergienko, O.V.; Lyashchuk, A.M.; Galushkina, Z.M.; Soboleva, L.A.; Osidak, E.O.; et al. Two Variants of Recombinant Human Bone Morphogenetic Protein-2 (rhBMP-2) with Additional Protein Domains: Synthesis in an Escherichia coli Heterologous Expression System. Biochemistry 2017, 82, 613-624. [CrossRef]

378. Bustos-Valenzuela, J.C.; Halcsik, E.; Bassi, E.J.; Demasi, M.A.; Granjeiro, J.M.; Sogayar, M.C. Expression, purification, bioactivity, and partial characterization of a recombinant human bone morphogenetic protein-7 produced in human 293T cells. Mol. Biotechnol. 2010, 46, 118-126. [CrossRef]

379. Brooks, S.A. Appropriate Glycosylation of Recombinant Proteins for Human Use: Implications of Choice of Expression System. Mol. Biotechnol. 2004, 28, 241-256. [CrossRef]

380. Sola, R.J.; Griebenow, K. Glycosylation of therapeutic proteins: An effective strategy to optimize efficacy. BioDrugs 2010, 24, 9-21. [CrossRef]

381. Carreira, A.C.; Lojudice, F.H.; Halcsik, E.; Navarro, R.D.; Sogayar, M.C.; Granjeiro, J.M. Bone morphogenetic proteins: Facts, challenges, and future perspectives. J. Dent. Res. 2014, 93, 335-345. [CrossRef]

382. Ratko, T.A.; Belinson, S.E.; Samson, D.J.; Bonnell, C.; Ziegler, K.M.; Aronson, N. AHRQ Technology Assessments. In Bone Morphogenetic Protein: The State of the Evidence of On-Label and Off-Label Use; Agency for Healthcare Research and Quality (US): Rockville, MD, USA, 2010.

383. Medtronic Sofamor Danek USA Inc. INFUSE Bone Graft Product Information: Lumbar; FDA gov: White Oak, MD, USA, 2002.

384. Medtronic Sofamor Danek USA Inc. INFUSE Bone Graft Product Information: Tibial; FDA gov: White Oak, MD, USA, 2004.

385. Medtronic Sofamor Danek USA Inc. INFUSE Bone Graft Product Information: Oral/Facial; FDA gov: White Oak, MD, USA, 2006.

386. Ong, K.L.; Villarraga, M.L.; Lau, E.; Carreon, L.Y.; Kurtz, S.M.; Glassman, S.D. Off-label use of bone morphogenetic proteins in the United States using administrative data. Spine 2010, 35, 1794-1800. [CrossRef] [PubMed]

387. Vaccaro, A.R.; Anderson, D.G.; Patel, T.; Fischgrund, J.; Truumees, E.; Herkowitz, H.N.; Phillips, F.; Hilibrand, A.; Albert, T.J.; Wetzel, T.; et al. Comparison of OP-1 Putty (rhBMP-7) to iliac crest autograft for posterolateral lumbar arthrodesis: A minimum 2-year follow-up pilot study. Spine 2005, 30, 2709-2716. [CrossRef] [PubMed]

388. Faundez, A.; Tournier, C.; Garcia, M.; Aunoble, S.; Le Huec, J.C. Bone morphogenetic protein use in spine surgery-complications and outcomes: A systematic review. Int. Orthop. 2016, 40, 1309-1319. [CrossRef] [PubMed]

389. Ye, F.; Zeng, Z.; Wang, J.; Liu, H.; Wang, H.; Zheng, Z. Comparison of the use of rhBMP-7 versus iliac crest autograft in single-level lumbar fusion: A meta-analysis of randomized controlled trials. J. Bone Miner. Metab. 2018, 36, 119-127. [CrossRef]

390. Liu, S.; Wang, Y.; Liang, Z.; Zhou, M.; Chen, C. Comparative Clinical Effectiveness and Safety of Bone Morphogenetic Protein Versus Autologous Iliac Crest Bone Graft in Lumbar Fusion: A Meta-analysis and Systematic Review. Spine 2020, 45, E729-E741. [CrossRef]

391. Dai, J.; Li, L.; Jiang, C.; Wang, C.; Chen, H.; Chai, Y. Bone Morphogenetic Protein for the Healing of Tibial Fracture: A Meta-Analysis of Randomized Controlled Trials. PLoS ONE 2015, 10, e0141670. [CrossRef]

392. Cahill, K.S.; Chi, J.H.; Day, A.; Claus, E.B. Prevalence, complications, and hospital charges associated with use of bone-morphogenetic proteins in spinal fusion procedures. JAMA 2009, 302, 58-66. [CrossRef] 
393. Williams, B.J.; Smith, J.S.; Fu, K.M.; Hamilton, D.K.; Polly, D.W., Jr.; Ames, C.P.; Berven, S.H.; Perra, J.H.; Knapp, D.R., Jr.; McCarthy, R.E.; et al. Does bone morphogenetic protein increase the incidence of perioperative complications in spinal fusion? A comparison of 55,862 cases of spinal fusion with and without bone morphogenetic protein. Spine 2011, 36, 1685-1691. [CrossRef]

394. Fu, R.; Selph, S.; McDonagh, M.; Peterson, K.; Tiwari, A.; Chou, R.; Helfand, M. Effectiveness and harms of recombinant human bone morphogenetic protein-2 in spine fusion: A systematic review and meta-analysis. Ann. Intern. Med. 2013, 158, 890-902. [CrossRef]

395. Carragee, E.J.; Hurwitz, E.L.; Weiner, B.K. A critical review of recombinant human bone morphogenetic protein-2 trials in spinal surgery: Emerging safety concerns and lessons learned. Spine J. 2011, 11, 471-491. [CrossRef]

396. James, A.W.; LaChaud, G.; Shen, J.; Asatrian, G.; Nguyen, V.; Zhang, X.; Ting, K.; Soo, C. A Review of the Clinical Side Effects of Bone Morphogenetic Protein-2. Tissue Eng. Part B Rev. 2016, 22, 284-297. [CrossRef]

397. Vaidya, R.; Weir, R.; Sethi, A.; Meisterling, S.; Hakeos, W.; Wybo, C.D. Interbody fusion with allograft and rhBMP-2 leads to consistent fusion but early subsidence. J. Bone Joint Surg. Br. 2007, 89, 342-345. [CrossRef]

398. Kim, H.K.; Aruwajoye, O.; Du, J.; Kamiya, N. Local administration of bone morphogenetic protein-2 and bisphosphonate during non-weight-bearing treatment of ischemic osteonecrosis of the femoral head: An experimental investigation in immature pigs. J. Bone Joint Surg. Am. 2014, 96, 1515-1524. [CrossRef] [PubMed]

399. Dumanian, Z.P.; Tollemar, V.; Ye, J.; Lu, M.; Zhu, Y.; Liao, J.; Ameer, G.A.; He, T.C.; Reid, R.R. Repair of critical sized cranial defects with BMP9-transduced calvarial cells delivered in a thermoresponsive scaffold. PLoS ONE 2017, 12, e0172327. [CrossRef]

400. Vhora, I.; Lalani, R.; Bhatt, P.; Patil, S.; Misra, A. Lipid-nucleic acid nanoparticles of novel ionizable lipids for systemic BMP-9 gene delivery to bone-marrow mesenchymal stem cells for osteoinduction. Int. J. Pharm. 2019, 563, 324-336. [CrossRef]

401. Chiari, C.; Grgurevic, L.; Bordukalo-Niksic, T.; Oppermann, H.; Valentinitsch, A.; Nemecek, E.; Staats, K.; Schreiner, M.; Trost, C.; Kolb, A.; et al. Recombinant Human BMP6 Applied Within Autologous Blood Coagulum Accelerates Bone Healing: Randomized Controlled Trial in High Tibial Osteotomy Patients. J. Bone Miner. Res. 2020. [CrossRef]

402. Krishnakumar, G.S.; Roffi, A.; Reale, D.; Kon, E.; Filardo, G. Clinical application of bone morphogenetic proteins for bone healing: A systematic review. Int. Orthop. 2017, 41, 1073-1083. [CrossRef]

403. Simmonds, M.C.; Brown, J.V.; Heirs, M.K.; Higgins, J.P.; Mannion, R.J.; Rodgers, M.A.; Stewart, L.A. Safety and effectiveness of recombinant human bone morphogenetic protein-2 for spinal fusion: A meta-analysis of individual-participant data. Ann. Intern. Med. 2013, 158, 877-889. [CrossRef]

404. Latzman, J.M.; Kong, L.; Liu, C.; Samadani, U. Administration of human recombinant bone morphogenetic protein-2 for spine fusion may be associated with transient postoperative renal insufficiency. Spine 2010, 35, E231-E237. [CrossRef]

405. Devine, J.G.; Dettori, J.R.; France, J.C.; Brodt, E.; McGuire, R.A. The use of rhBMP in spine surgery: Is there a cancer risk? Evid. Based Spine Care J. 2012, 3, 35-41. [CrossRef]

Publisher's Note: MDPI stays neutral with regard to jurisdictional claims in published maps and institutional affiliations.

(C) 2020 by the authors. Licensee MDPI, Basel, Switzerland. This article is an open access article distributed under the terms and conditions of the Creative Commons Attribution (CC BY) license (http://creativecommons.org/licenses/by/4.0/). 